\title{
THE STUDY OF TYPE COLLECTION IN CONSERVATOIRE ET JARDIN BOTANIQUE DE LA VILLE DE GENÈVE (G): THE HEPATIC GENERA JUNGERMANNIA, SOLENOSTOMA AND PLECTOCOLEA ИЗУЧЕНИЕ ТИПОВЫХ ОБРАЗЦОВ В ГЕРБАРИИ ЖЕНЕВСКОГО БОТАНИЧЕСКОГО САДА (G): РОДЫ ПЕЧЕНОЧНИКОВ JUNGERMANNIA, SOLENOSTOMA И PLECTOCOLEA

\author{
VADIM A. BAKALIN 1,2
} \\ ВАДИМ А. БАКАЛИН ${ }^{1,2}$
}

\begin{abstract}
Type specimens of 75 hepatics taxa currently accepted in Jungermannia, Solenostoma and Plectocolea were studied in the type collection of G. Their systematic position and correct names are discussed. Nomenclature citations (including data from original specimen labels) are presented, most of them are accompanied by morphological descriptions and newly compiled pictures. New lectotypes are selected for Aplozia stephanii Schiffn. and Jungermannia spongiosa Steph. The neotype for Jungermannia thermarum Steph. is designated. Jungermannia danicola Gottsche ex Underw. is synonymized with Solenostoma sphaerocarpum (Hook.) Steph. and Solenostoma purpuratum var. koponenii Bakalin et Li Wei is synonymized with Solenostoma purpuratum (Mitt.) Steph. var. gollanii (Steph.) Bakalin. Fifteen new combinations (Solenostoma papullosum (Steph.) Bakalin comb. nov., Plectocolea callithrix (Lindenb. et Gott.) Bakalin comb.nov., Plectocolea gollanii (Steph.) Bakalin comb. nov., Plectocolea glauca (Amak.) Bakalin comb. nov., Plectocolea montana (Steph.) Bakalin comb. nov., Solenostoma gracillimum var. heteromorpha (Gott. et Rabenh.) Bakalin comb. nov., Plectocolea decolor (Schiffn) Bakalin comb. nov., Plectocolea newellana (Steph.) Bakalin comb. nov., Plectocolea renauldii (Steph.) Bakalin comb. nov., Plectocolea sexplicata (Steph.) Bakalin comb. nov., Plectocolea dusenii (Steph.) Bakalin comb. nov., Plectocolea obliquifolia (Schiffn.) Bakalin comb. nov., Plectocolea vulcanicola (Schiffn.) Bakalin var. tenuiretis (Schiffn.) Bakalin comb. nov., Plectocolea vulcanicola (Schiffn.) Bakalin var. tenuiretis (Schiffn.) Bakalin f. cavifolia (Schiffn.) Bakalin comb. nov., Solenostoma purpuratum (Mitt.) Steph. var. gollanii (Steph.) Bakalin comb. nov.) are proposed. The species status of Solenostoma marcescens (Mitt.) Bakalin and Plectocolea yunnanensis Bakalin is confirmed.
\end{abstract}

Резюме

Типовые образцы 75 таксонов печеночников из родов Jungermannia, Solenostoma и Plectocolea изучены в гербарии G. Обсуждены систематическая позиция и правильные названия для всех таксонов. Полные номенклатурные цитаты (включая данные с оригинальных этикеток) в большинстве случаев сопровождаются морфологическими описаниями и оригинальными иллюстрациями. Новые лектотипы предложены для Aplozia stephanii Schiffn. и Jungermannia spongiosa Steph. Для Jungermannia thermarum Steph. выбран неотип. Jungermannia danicola Gottsche ex Underw. синонимизирована с Solenostoma sphaerocarpum (Hook.) Steph., a Solenostoma purpuratum var. koponenii Bakalin et Li Wei - c Solenostoma purpuratum (Mitt.) Steph. var. gollanii (Steph.) Bakalin. Предложены 15 новых комбинаций: Solenostoma papullosum (Steph.) Bakalin comb. nov., Plectocolea callithrix (Lindenb. et Gott.) Bakalin comb. nov., Plectocolea gollanii (Steph.) Bakalin comb. nov., Plectocolea glauca (Amak.) Bakalin comb. nov., Plectocolea montana (Steph.) Bakalin comb. nov., Solenostoma gracillimum var. heteromorpha (Gott. et Rabenh.) Bakalin comb. nov., Plectocolea decolor (Schiffn) Bakalin comb. nov., Plectocolea newellana (Steph.) Bakalin comb. nov., Plectocolea renauldii (Steph.) Bakalin comb. nov., Plectocolea sexplicata (Steph.) Bakalin comb. nov., Plectocolea dusenii (Steph.) Bakalin comb. nov., Plectocolea obliquifolia (Schiffn.) Bakalin comb. nov., Plectocolea vulcanicola (Schiffn.) Bakalin var. tenuiretis (Schiffn.) Bakalin comb. nov., Plectocolea vulcanicola (Schiffn.) Bakalin var. tenuiretis (Schiffn.) Bakalin f. cavifolia (Schiffn.) Bakalin comb. nov., Solenostoma purpuratum (Mitt.) Steph. var. gollanii (Steph.) Bakalin comb. nov. Подтверждена самостоятельность Solenostoma marcescens (Mitt.) Bakalin и Plectocolea yunnanensis Bakalin.

KEYWORDS: hepatics, Jungermanniaceae, Solenostomataceae, Jungermannia, Solenostoma, Plectocolea, taxonomy, type specimens.

\footnotetext{
1 - Botanical Garden-Institute of FEB RAS, Makovskogo Street, 142, Vladivostok, 690024, Russia; e-mail: v_bak@list.ru;

2 - Institute of Biology and Soil Science, Stoletiya Vladivostoka Avenue, 159, Vladivostok, 690022, Russia
} 


\section{INTRODUCTION}

The type collection in Conservatoire et Jardin Botanique de la Ville de Genève $(\mathrm{G})$ is of outstanding value for understanding hepatic species described by Franz Stephani (1842-1927), since this collection includes most of type specimens. In addition, $G$ has also many types of taxa described by other bryologists and accumulated by Stephani in his herbarium. The last sketch of Stephani's life and working activity was published by Gradstein (2006).

The revisions of Stephani's Jungermannia s.l. (incl. Solenostoma, Plectocolea and Liochlaena) were undertaken by several bryologists with the most valuable input made by Amakawa (1960, 1966, 1967, 1968, 1969, etc.) and Váňa (1972a, 1972b, 1974a, 1974b, etc.). These works were carried out more than forty years ago and need revision due to two circumstances:

1) In most cases authors of cited works did not provide descriptions and illustrations based entirely on the Stephani's types and just gave generalized descriptions of the species with providing synonyms under priority name. Moreover, miscellaneous works devoted to Asian Jungermannia s.l. (Váňa,1972a, 1972b, 1974d, 1975c) commonly provided only lists of synonyms, including syn. nov., without discussion and, sometimes, only with references to illustrations from unpublished Icones Hepaticarum, which were criticized for being too schematic and ill-illustrative (Gradstein, 2006). From the very start of my revision, I found some of these synonyms incorrect. Sometimes type specimens of synonymyzed taxa differ significantly in morphological characters and sexual condition (Bakalin, 2013).

2) Recent results of molecular phylogenetic analyses of Jungermannia s.l. showed that some characters which were considered unimportant, e.g., plant coloration, have taxonomical significance, providing evidence in favor of splitting some species into more narrow entities. Thus, to avoid superfluous descriptions it is essential to make sure that they have not been described ealier under different epithets.

These reasons inspired me to study Stephani types in $\mathrm{G}$ and provide their description, which was in addition required as many specimens are very small and in poor condition (loss of original color and shape due to repeated soaking, collapsed leaf cells, etc.). Descriptions presented in this work were compiled during my stay in Genève in October 2013, at the same time I made several photographs of the type material using both translucent and dissecting microscopes and figures presented here are made from these photographs. The figures, descriptions and/or taxonomic discussions are provided for each taxa, which are characterized mainly by five following sections:

1) Basionym, with the nomenclatural citation. All discussed taxa are ranged alphabetically by basionym name.

2) Type status, label citation and G database number(s). In many cases type specimens in $\mathrm{G}$ have two kinds of barcodes: old ones not presented in the available databases, but commonly appearing in publications over 10 years ago, and a new ones, corresponding to a certain number in the on-line accessible database (http:/ /www.ville-ge.ch/musinfo/bd/cjb/chg/?lang=en). If both barcodes are present I cite both and divide them by slash (/). No slash used if only one (new) barcode is present on the sheet.

3) Accepted name in accordance with modern taxonomical concept implying recognition of Plectocolea, Solenostoma and Endogemma as distinct genera.

4) Morphological description (for most species except few isotypes of well known species). Sometimes a description is brief due to poor specimen condition, with sometimes collapsed leaf cells not allowing exact measurements of both leaf and cell size.

5) Comments on taxonomy.

\section{TYPE SPECIMEN DESCRIPTION AND DISCUSSION}

1) Aplozia stephanii Schiffn., Denkschr. Kaiserl. Akad. Wiss., Wien Math.-Naturwiss. Kl. 67: 195. 1898.

Lectotypus novus: Aplozia stephanii Schiffn. Java. Prov. Praenger. in regione superiore montis ignivomi Gedeh infra craterem ad terram. Regio alpina, alt. $~ 2700$ m s. m. 10.VII.1894 V. Schiffner (No. 520) G00120794.

Accepted name: Solenostoma stephanii (Schiffn.) Steph., Sp. Hepat. 2: 58. 1901.

Description. Plants prostrate, rarely ascending, yellowish-brownish, 2.5-3.5 mm wide and 7-12 mm long, rather rigid, commonly dorsiventrally flattened. Stem ca. $350-400 \mu \mathrm{m}$ in diameter, not branched, with exception of lateral subfloral innovations, yellowish-brownish. Rhizoids brownish, originated mostly near ventral leaf base, obliquely spreading or decurrent down the stem, but not forming the fascicle. Leaves concave-canaliculate, obliquely inserted, laterally spreading, sometimes with recurved dorsal leaf margin, shortly (up to $1 / 4$ of stem width) decurrent dorsally, subtransversely to arcuately inserted ventrally, where not or barely decurrent, contiguous to subimbricate, sometimes enclosed one to another, suborbicular to ovate, $1300-1500 \times 1500-1750$ $\mu \mathrm{m}$, mostly narrowly revolute along margin (especially in dorsal side). Midleaf cells subisodiametric to oblong, $37.5-57.0 \times 31.0-42.5 \mu \mathrm{m}$, thin-walled, trigones moderate in size, convex, cuticle smooth; cells along leaf margin $25.0-37.5 \mu \mathrm{m}$, thin-walled, external wall thickened, trigones moderate in size to large, convex, rarely confluent, cuticle virtually smooth. Dioicous. Perianth 4(-5)plicate in upper $3 / 4$ or at the whole extent, gradually or more or less suddenly contracted to not or indistinctly beaked mouth, exerted for $1 / 2-2 / 5$ of its length, ca. $2250 \times 1000 \mu \mathrm{m}$, composed by isodiametric cells; perigynium absent or very low; female bracts similar to large leaves, sheathing the perianth, concave to concave-canaliculate. (Fig. 1: 1-5).

Comment. The species was described by Schiffner (1898) based on 11 specimens from Java and western 

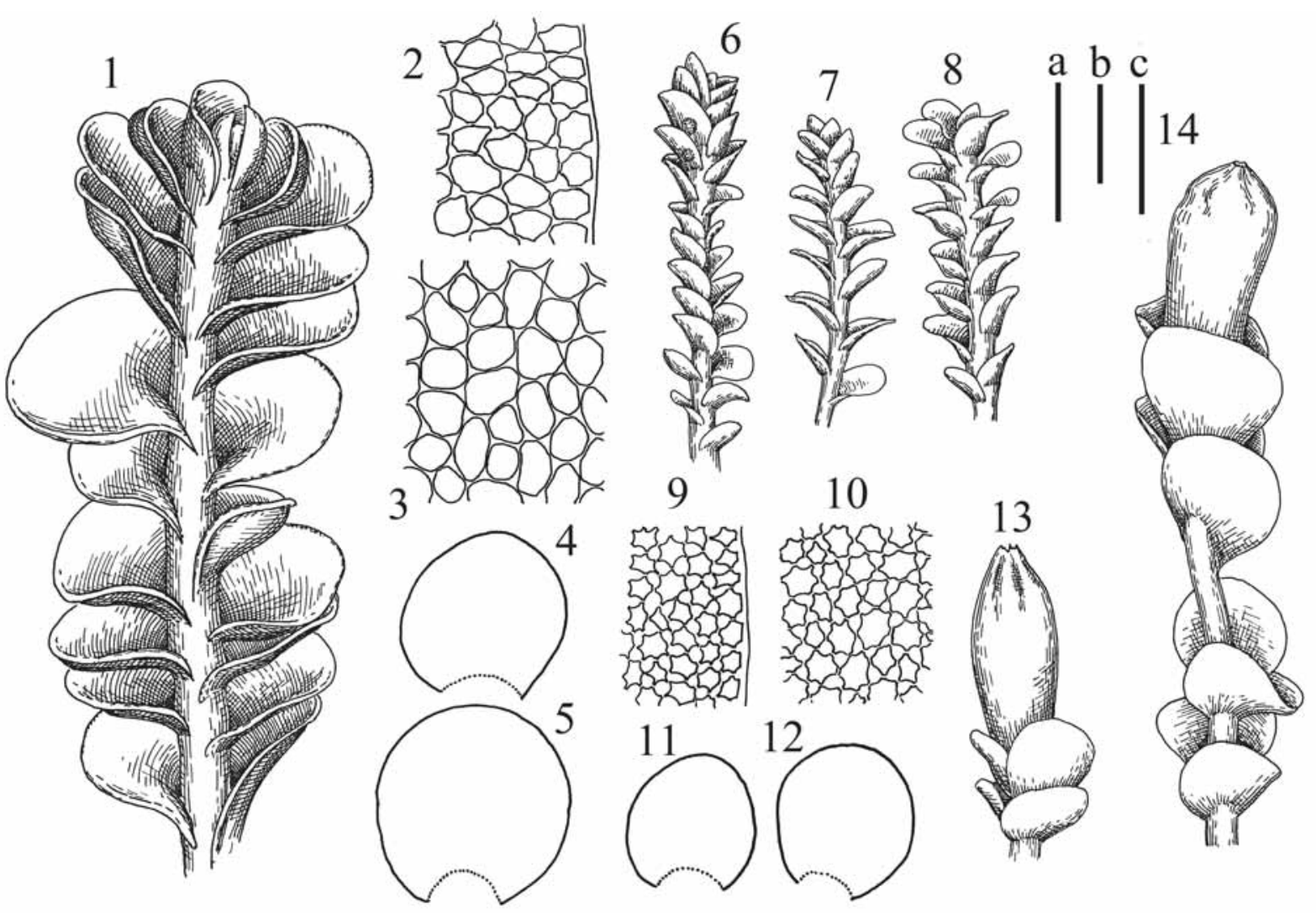

Fig. 1. Aplozia stephanii Schiffn., lectotype (G00120794): 1 - plant habit; 2 - cells along leaf margin; 3 - midleaf cells; 4, 5 leaves; Aplozia stricta Schiffn., syntype (G3716/00120987): 6-8 - plant habit; 9 - cells along leaf margin; 10 - midleaf cells, 11, 12 - leaves, 13 - upper part of perianthous plant; Jungermannia appressifolia Mitt., isotype (G14665/00120007): 14 - perianthous plant. Scales: $\mathrm{a}-1 \mathrm{~mm}$, for $1,4-8,13,14 ; \mathrm{b}-100 \mu \mathrm{m}$, for $2,3,9,10 ; \mathrm{c}-500 \mu \mathrm{m}$, for 11,12 .

Sumatra. The first of mentioned specimens and only one of two having perianths is from Praenger Province. It fits well to the original description and is selected as the lectotype.

2) Aplozia stricta Schiffn., Denkschr. Kaiserl. Akad. Wiss., Wien Math.-Naturwiss. K1. 67: 194. 1898.

Syntypus: Sumatra occidentalis. In monte ignivomo Merapi in silva primaeva ad terram. Regio nubium, alt. 2120 m s. m. 31.VII.1894 V. Schiffner (No. 515) G3716/ 00120987.

Accepted name: Solenostoma strictum (Schiffn.) Váňa, Hentschel \& J. Heinrichs, Cryptogamie, Bryologie 31(2): 138. 2010.

Description. Plants brownish to yellowish-brownish, ascending, in loose mats, rather rigid, $0.75-1.25 \mathrm{~mm}$ wide and 5-7 mm long. Stem 125-200 $\mu \mathrm{m}$ in diameter, not branched, with the exception of ventral subfloral innovations, brownish to brown. Rhizoids virtually absent to numerous, obliquely spreading in unclear fascicle or decurrent down the stem, but not forming fascicle, colorless to grayish. Leaves obliquely to erect spreading, distant to (rarer) contiguous, concave-canaliculate, transversely to subtransversely inserted, dorsally not or barely decurrent, ventrally arcuately inserted, not or barely decurrent, nearly suborbicular, 300-600×350-600 $\mu \mathrm{m}$. Midleaf cells subisodiametric to shortly oblong, 31.2-
$42.5 \times 25.0-37.5 \mu \mathrm{m}$, thin-walled, cuticle distinctly papillose, trigones large, convex to bulging; cells along leaf margin 12.5-27.5 $\mu \mathrm{m}$, thin-walled, external wall thickened, trigones large, bulging, sometimes confluent, cuticle loosely papillose. Dioicous. Androecia intercalary, with 3-4 pairs of bracts, bracts similar to leaves, but inflated in lower half and erect spreading to recurved in upper third. Perianth ca. $1750 \times 750 \mu \mathrm{m}$, nearly fusiform to clavate, 3(-4)-plicate in upper $1 / 4-1 / 3$, gradually narrowed to not or indistinctly beaked mouth; perigynium virtually absent; female bracts similar to leaves, concavecanaliculate, loosely sheathing perianth near base and erect to obliquely spreading above. (Fig. 1: 6-13).

Comments: a) The species was described by Schiffner (1898) based on four specimens from Java and western Sumatra. According to protologue, three of four syntypes have perianths and antheridia (Schiffner, 1898). The single syntype in $\mathrm{G}$ (cited above) has perianth and agrees with protologue in essential details.

b) Amakawa's (1968) description of this taxon is based on two other syntypes from Java (incorrectly cited by Amakawa as from "F", but really being from $\mathrm{FH}$ ). That description is slightly different from the given above, especially in the rhizoids characteristic. Amakawa (1968: 105) states that rhizoids are "forming a bundle along the stem", while rhizoids in the specimen from G are com- 
monly decurrent down the stem, but not forming a fascicle. Also the size of plant in $\mathrm{G}$ is smaller than in Amakawa (1.c.).

3) Jungermannia abyssinica Nees, Synopsis Hepaticarum 93. 1844.

Isotypus: Abyssinia. In montis Silke, supra regionem fruticum ad rivules et rupes umbroses. 22.II.1840. W.P. Schimper (s.n.) G14427/00069029.

Accepted name: Solenostoma abyssinicum (Nees) Steph., Sp. Hepat. 2: 53. 1901.

Description. Plants erect in dense patches, yellowish-brownish, $2.0-2.75 \mathrm{~mm}$ wide, $8-15 \mathrm{~mm}$ long, more or less rigid. Stem $300-350 \mu \mathrm{m}$ in diameter, yellowishbrownish, sometimes slightly flexuous, not branched (even as subfloral innovations). Rhizoids numerous, brownish, originated near ventral leaf base and from other parts of ventral side of stem, obliquely spreading in unclear fascicles or decurrent down along the stem and form fascicle, which is mostly unclear. Leaves obliquely spreading to slightly laterally appressed to the stem, concave to canaliculate-concave, subtransversely inserted, dorsally decurrent for (1/4) 1/2-3/4 of stem width, ventrally transversely to arcuately inserted, decurrent for $1 / 2-3 / 4$ of stem width, contiguous to subimbricate, sometimes (large leaves) slightly undulate at margin, suborbicular, transversely elliptic to widely ovate in shape, $1000-1500 \times$ $1300-2050 \mu \mathrm{m}$. Midleaf cells $25.0-44.0 \times 25.0-30.0 \mu \mathrm{m}$, thin-walled, trigones moderate in size to small, triangle to slightly convex, cuticle smooth; cells along leaf margin $12.5-20.0 \mu \mathrm{m}$, thin-walled, with moderate in size, triangle to slightly concave or convex trigones, external wall thickened. Paroicous? (Androecia not found). Perianth 4-5-plicate in upper $1 / 2-2 / 5$ of its length, suddenly contracted to not beaked mouth, composed by subisodiametric to shortly oblong cells, exerted for $3 / 5-2 / 3$ of its length; perigynium virtually absent or very low; female bracts similar to large leaves, loosely sheathing perianth near base and obliquely spreading above, concave-canaliculate. (Fig. 2: 1-7).

Comments: a) Another isotype of Jungermannia abissinica G14432/00069033 is identical to above described, although plants are rather ascending than erect and more lax. I suggest this specimen represents a weak phase of the species.

b) The species is commonly regarded as paroicous, but I was not able to find traces of antheridia or their stalks in leaves below the perianth bracts.

c) The detailed description by Váňa (1974b) provides size of plants up to $1.9 \mathrm{~mm}$ wide, the plants in the specimen described here are slightly wider (up to $2.75 \mathrm{~mm}$ ).

4) Jungermannia appressifolia Mitt., J. Proc. Linn. Soc. 5: 91. 1860[1861].

Isotypus: Himalayae orient. reg. temp. Sikkim, alt. 7000 ft. J.D. Hooker (No. 1326) G14665/00120007.

Accepted name: Solenostoma appressifolium (Mitt.) Váňa \& D.G. Long, Nova Hedwigia 89: 494. 2009.
Comments: a) The specimen contains most common form of the species with concave and appressed to stem leaves; rhizoids in distinct fascicles decurrent down the stem, colorless to grayish in color.

b) This is well known species described many times, full synonymy is given by Ván̆a (1972b) and the best description and illustrations - by Amakawa (1960) under Jungermannia clavellata.

5) Jungermannia baldwinii Steph., Sp. Hepat. 6: 83. 1917.

Holotypus: Hawaji. In insula Maui occidentalis 1875. D.D. Baldwin (n. 94 p.p.) G14296/00043701.

Accepted name: ?Plectocolea micrantha Mitt. in Seeman, Fl. Vitiensis 405. 1871.

Description. Plants rather erect, yellowish-brownish to brownish, 1.5-2.25 $\mu \mathrm{m}$ wide and 20-30 mm long, laterally compressed. Stem $300-375 \mu \mathrm{m}$ in diameter, not branched, with the exception of ventral leafless stolons, turning into normal branch, flexuous. Rhizoids sparse, brownish to purplish-brown, obliquely spreading. Leaves laterally appressed to the stem, flattened to slightly concave, suborbicular to transversely elliptic, ca. $1150 \times 1750$ $\mu$ m. (Fig. 2: 8).

Comment. Váňa (1975b) regarded this name as a synonym of Jungermannia micrantha. Due to his observations Jungermannia baldwinii is probably an aquatic modification, characterized by large sized, pale green colored plants, with rather large leaf cells almost without trigones. I have shown earlier that the type of $P$. micrantha is paroicous (Bakalin, 2013). Unfortunately, the type material of $J$. baldwinii is sterile and I was unable to check the sex distribution type. Also the material in the holotype is scanty and in bad condition, with cells strongly collapsed probably due to repeated soaking, which precludes further discussion on the systematic position of this taxon.

6) Jungermannia borgenii Gottsche, Forhandlinger Vidensk.-Selsk. Kristiania 1892(14): 11. 1893.

Isotypus: Madagascar. M. Borgen G14433/00045605. Accepted name: Solenostoma sp.

Description. Plants pallid, pale greenish-brownish, slightly pellucid, rather prostrate, $0.25-0.4 \mathrm{~mm}$ wide, $3-$ $5 \mathrm{~mm}$ long, loosely laterally flattened. Stem $40-75 \mu \mathrm{m}$ in diameter, sparsely laterally and ventrally branched (ventral branches originated as geotropic stolons, but becoming into normal branches soon). Rhizoids colorless, sparse, originated near ventral leaf base, but not only there, obliquely to erect spreading, separated (not united into fascicles). Leaves concave-canaliculate, obliquely to erect spreading, contiguous to subimbricate and arranged in tile to each other, obliquely to nearly transversely inserted, dorsally not or barely decurrent, ventrally transversely to nearly arcuately inserted, not or barely decurrent, suborbicular to widely ovate, 250$300 \times 350-375 \mu \mathrm{m}$. Midleaf cells shortly elongate, thin- 

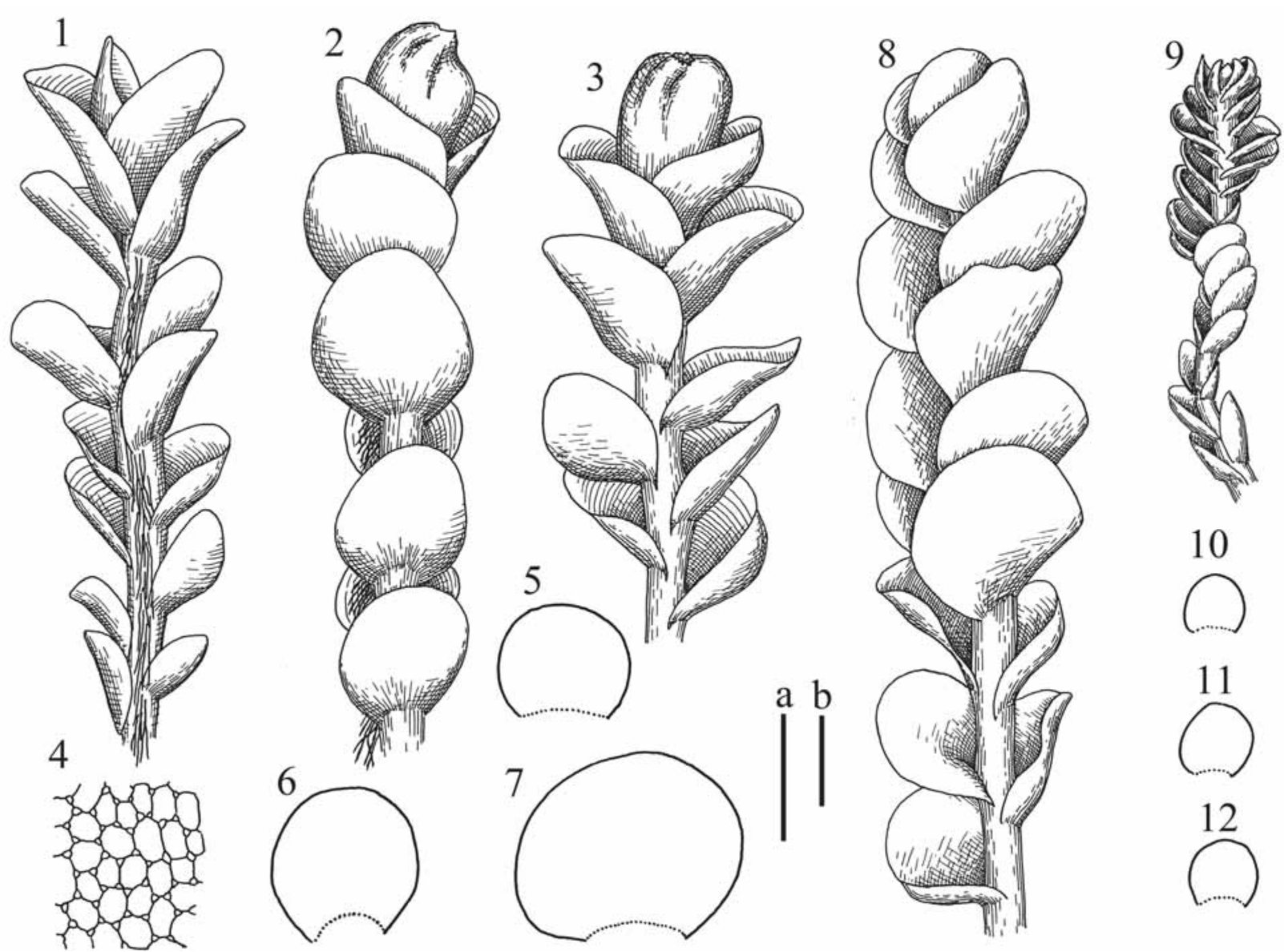

Fig. 2. Jungermannia abyssinica Nees, isotype (G14427/00069029): 1 - plant habit, ventral view; 2, 3 - perianthous plants; 4 - midleaf cells; 5-7 - leaves; Jungermannia baldwinii Steph., holotype (G14296/00043701): 8 - plant habit; Jungermannia borgenii Gottsche, isotype (G14433/00045605): 9 - plant habit; 10-12 - leaves. Scales: a - $1 \mathrm{~mm}$, for 1-3, 5-8; b - 100 $\mu \mathrm{m}$, for 4; $\mathrm{a}-500 \mu \mathrm{m}$, for $9-12$.

walled, 25.0-34.0×15.0-19.0 $\mu \mathrm{m}$, trigones small, concave, cuticle papillose; cells along leaf margin 15.0-20.0 $\mu \mathrm{m}$, thin-walled, trigones small, concave, cuticle virtually smooth. (Fig. 2: 9-12).

Comment. The specimen was designated as isotype of Jungermannia borgenii by Váňa (1974b). However, plants in the specimen are much smaller than those commonly described (e.g. in Váňa, 1974b), both in general habit and leaf cell size. Another difference is in distinctly papilliferous cuticle. I refrain to regard plants described above as a simple depauperate form of Solenostoma borgenii (Gott.) Steph., because no any features of etiolation were found (e.g., distant leaves) in the specimen. Also cell size in depauperate plants is commonly the same or only slightly smaller than in normally developed plants. I was unable to find any morphologically similar taxa known from Africa and adjacent areas. I have not studied the holotype of the taxon and I am not sure plants in holotype and isotype are identical. If the description given by Váňa (1974b) is based on holotype and is correct, the aforementioned specimen (G14433/00045605) probably represents another, previously not described taxon. Unfortunately, this problem demands to examine not only holotype specimen, but also more copious and fertile material. The studied 'isotype' contains only few plants, and all of those are sterile.

7) Jungermannia brasiliensis Steph., Sp. Hepat. 2: 79. 1901. (non Jungermannia brasiliensis Raddi, Crittogame Brasiliane, 15. 1822., non Jungermannia brasiliensis Nees, Enumeratio Plantarum Cryptogamicarum Javae, 11. 1830.)

Holotypus: Brasilia. Minas gera,s. Martius G14450/ 00067684.

Accepted name: Solenostoma papulosum (Steph.) Bakalin comb. nov. Basionym: Jungermannia papulosa Steph., Sp. Hepat. 2:73. 1901.

Description. Plants prostrate (?, only 6 plants are present in the type), pale brownish, $0.7-1.0 \mathrm{~mm}$ wide and 5-7 mm long. Rhizoids sparse, but dense in lower part of stem, obliquely spreading, colorless to grayish and brownish. Stem ca. $120 \mu \mathrm{m}$ in diameter, not branched, pale yellowish brownish, more deeply colored in ventral side. Leaves slightly concave to concave-canaliculate, laterally spreading (such as plants looks dorsiventrally flattened), obliquely inserted, dorsally barely decurrent, ventrally sub- to transversely inserted, not decurrent, ovate, ca. $220 \times 120 \mu \mathrm{m}$. Midleaf cells oblong, 27.5- 

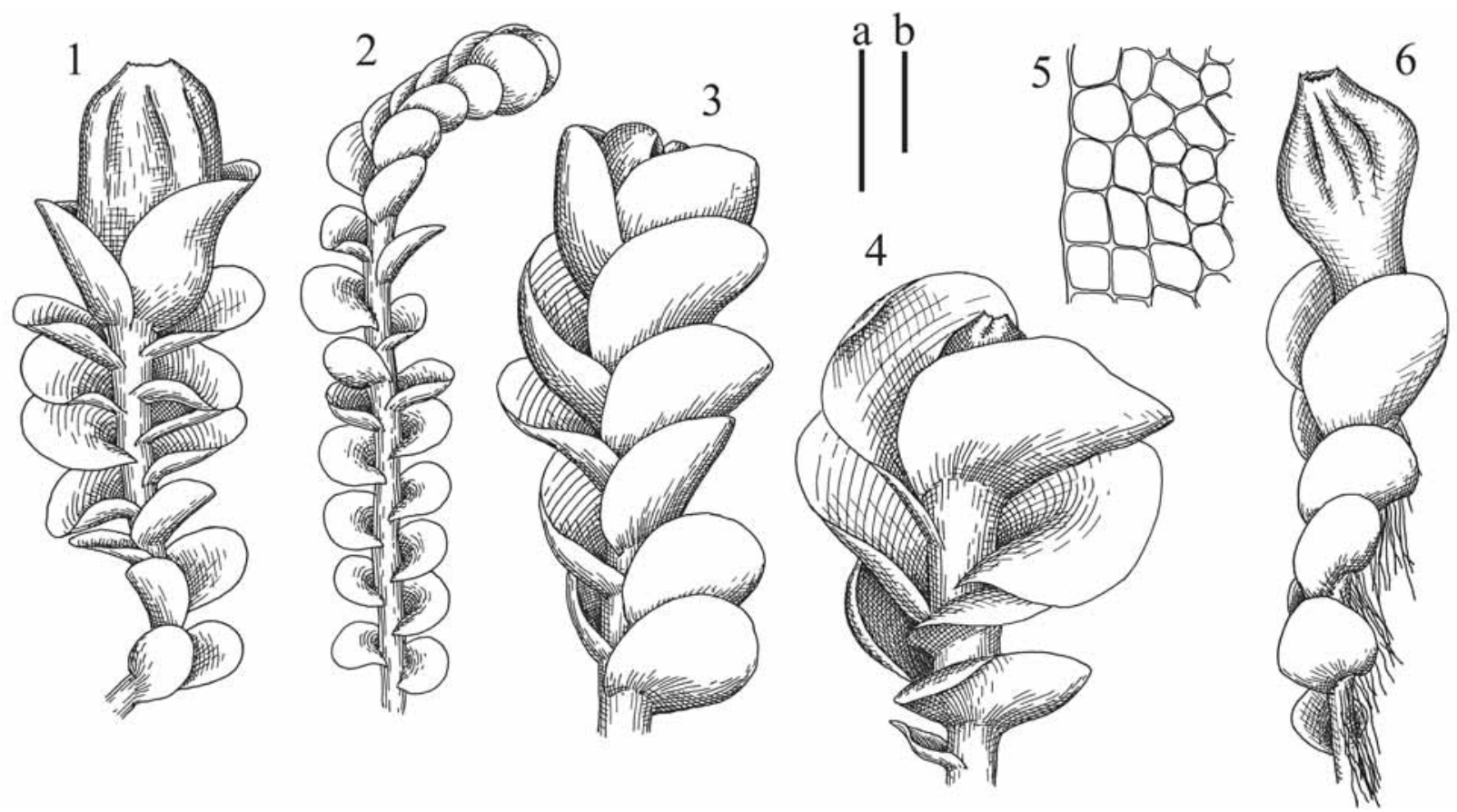

Fig. 3. Jungermannia brasiliensis Steph., holotype (G14450/00067684): 1 - perianthous plant; 2 - plant habit; Jungermannia cambewarrana Steph., holotype (G14297/00128127): 3, 4- perianthous plants; Jungermannia caespeticia Lindenb., isotype (G00115178): 5 - cells along leaf margin; 6 - perianthous plant. Scales: $\mathrm{a}-1 \mathrm{~mm}$, for 3, 4, 6; b-100 $\mu \mathrm{m}$, for 5; a - $500 \mu \mathrm{m}$, for $1,2$.

$50.0 \times 19.0-34.0 \mu \mathrm{m}$, thin-walled, trigones small to moderate in size, concave; cells along leaf margin 19-31 $\mu \mathrm{m}$, with moderately thickened walls, and thickened external wall, trigones moderate in size; cuticle smooth with the exception of leaf base, where papillose-striolate. Dioicous? Perianth 3-plicate in upper part, ellipsoidal, gradually narrowed to obscurely beaked mouth. (Fig. 3: 1, 2).

Comment. Váňa (1974a) regarded this name as synonymous with two other names: Jungermannia papulosa Steph. (Sp. Hepat. 2: 73. 1901) also described from "Brasilia. Minas geraës" based on collection by Lindmann (No. 23 p.p.), and with Jungermannia amoena Lindenb et Gott. Synopsis Hepat. 674. 1847. (=Solenostoma amoenum (Lindenb. \& Gottsche) R.M. Schust. ex Váňa, Hentschel \& J. Heinrichs) based on collection by Liebmann from Mexico. The latter name has priority. However, the plants in holotype of $J$. brasiliensis Steph. differ in many features from Solenostoma amoenum in the treatment by Ván̆a (1974a), including pale color of plants, smaller size of shoots (although they are not depauperate), smaller leaf cells which are also oblong in midleaf, but not isodiametric, etc. I regard J. brasiliensis Steph. as synonymous with J. papulosa that should be named in current taxonomy as Solenostoma papulosum (Steph.) Bakalin (see below).

8) Jungermannia caespiticia Lindenb., Nova Acta Phys.-Med. Acad. Caes. Leop.-Carol. Nat. Cur. 14 (Suppl.): 67.1829.

Isotypus: Germany. "Ad Bergedorf in silvaticis". Anonymous. G00115178. (marked as "Original von Lindenberd" by Stephani)
Accepted name Endogemma caespiticia (Lindenb.) Konstant., Vilnet \& A. V. Troitsky, Folia Cryptogamica Estonica 48: 132. 2011.

Description of leaf cells. Midleaf cells 50.0 $62.5 \times 31.0-37.5 \mu \mathrm{m}$, very thin-walled, oblong to subisodiametric, hexagonal, trigones vestigial; cells along margin $37.5-50.0 \mu \mathrm{m}$, trigones small to moderate in size, concave, external wall thickened, other walls also slightly thickened. (Fig. 3: 5, 6)

Comment. The plants in the specimen bear two features unusual for most common forms of E. caespiticia: slightly thickened walls in the cells along leaf margin and sometimes moderate in size trigones in leaf marginal cells.

9) Jungermannia cambewarrana Steph., Sp. Hepat. 6: 84. 1917.

Holotypus: Australia. New South Wales, Cambewarra Pass. V.1903. W.W. Watts. G14297/00128127.

Accepted name: Solenostoma orbiculatum (Colenso) R.M. Schust. "orbiculata", Nova Hedwigia Beiheft 119: 380. 2002.

Description. Plants rather ascending, yellowish-greenish to brownish, in more or less dense patches, 1.5-2.0 mm wide and 4-7 mm long. Rhizoids dense, in unclear obliquely spreading fascicles or in mat under the stem, colorless to grayish. Stem 270-370 $\mu \mathrm{m}$ in diameter, yellowish-brown, not branched (even as subfloral innovations). Leaves concave to concave-canaliculate, obliquely inserted, barely decurrent down (up 1/4 of stem width), ventrally arcuately inserted, not or barely decurrent, suborbicular to transversely 

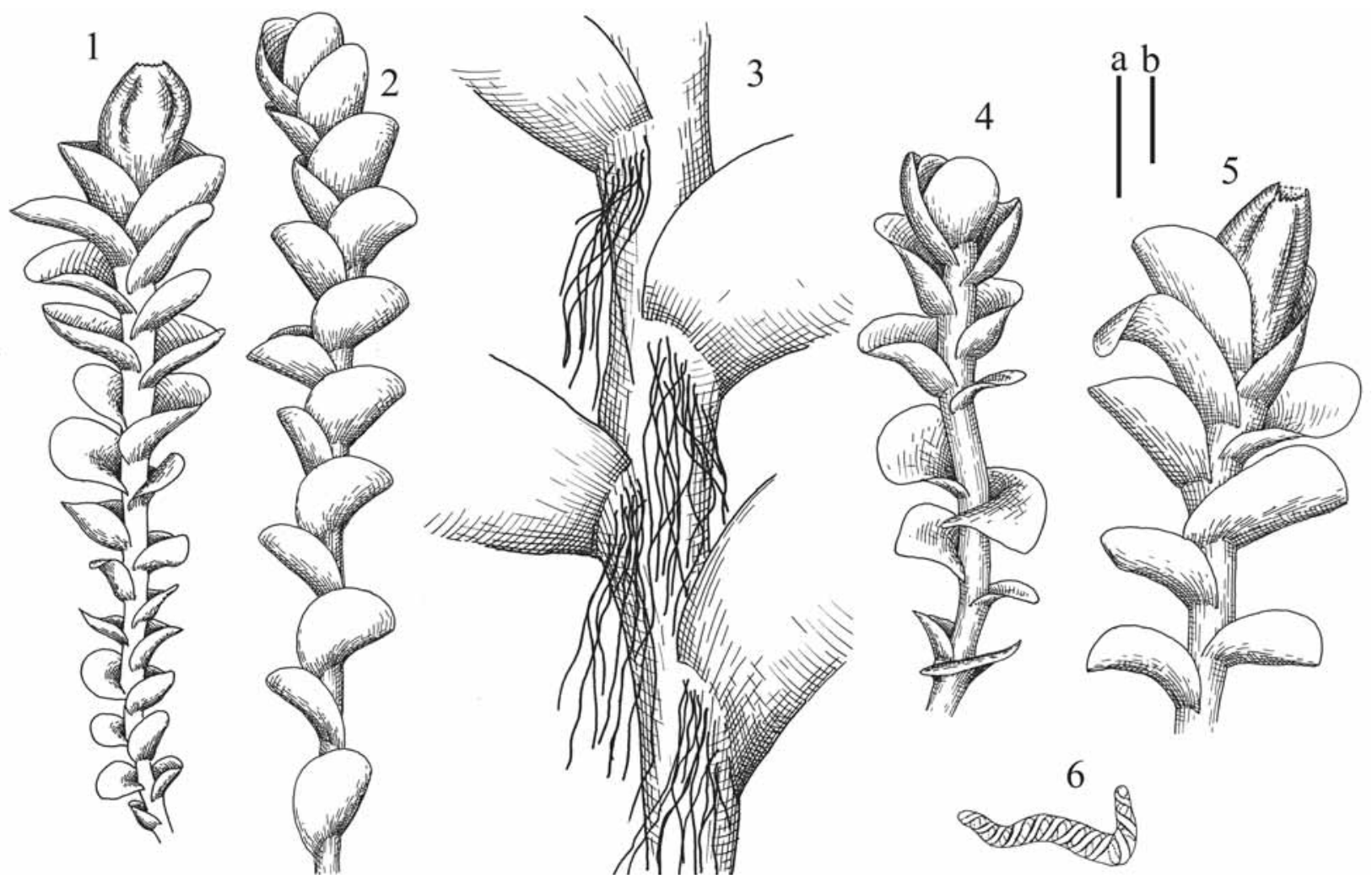

Fig. 4. Jungermannia caucasica Váňa, isotype (G00015179): 1 - perianthous plant; Jungermannia decurrens Steph., isotype (G00115348): 2 - plant habit; Jungermannia mosenii Steph., holotype (G14482/00112142): 3 - fragment of ventral view; 4 plant habit; 5 - perianthous plant; 6 - elater. Scales: a - $1 \mathrm{~mm}$, for $1,2,4,5 ; \mathrm{b}-50 \mu \mathrm{m}$, for 6 ; a $-500 \mu \mathrm{m}$, for 3 .

elliptic, 1100-1800×1500-2200 mm, contiguous. Midleaf cells subisodiametric, $25-34 \times 31-38 \mu \mathrm{m}$, thin-walled, trigones moderate, slightly concave to convex, cuticle smooth; cells along leaf margin 28-40 $\mu \mathrm{m}$, thin-walled, external wall thickened, trigones moderate to large, convex, cuticle smooth. Dioicous? Perianth (only young perianth seen) hidden within bracts, not beaked, 4-5-plicate starting from the very base. (Fig. 3: 3, 4).

Comment. Ván̆a (1975a) regarded this name as synonymous with Jungermannia orbiculata (Col.) Grolle Journ. Jap. Bot. 41: 144. 1966. (=Solenostoma orbiculatum (Colenso) R.M. Schust.) described from New Zealand. Váňa (1.c.) also regarded J. cambewarrana as the taxon described basically for geographic reasons and well agreeing in complex features with $J$. orbiculata, being only different from typical phase of the latter in quite rarer rhizoids. In my estimate the plants in the type of $J$. cambewarrana are also slightly smaller than typical Solenostoma orbiculatum, but not deserving splitting from the latter. 1970

10) Jungermannia caucasica Váňa, Preslia 42: 46.

Isotypus: Georgia. Adjara, prope lacum in decl. montis Mtirala. 20.VII.1961. A.L. Abramova et I.I. Abramov (LE1805) G00015179.

Accepted name: Solenostoma caucasicum (Váňa) Konstant., Arctoa 1: 123. 1992. (Fig. 4: 1)
Description. Plants bright green to greenish-yellowish, rather creeping, rarely ascending. Rhizoids colorless to brownish, erect to obliquely spreading. Leaves subtransversely inserted, concave to cupped, in bigger plants concave-canaliculate, widely ovate to widely obliquely ovate when flattened, ca. $0.62 \times 0.85 \mathrm{~mm}$ in sterile plants up to $1.25 \times 1.5 \mathrm{~mm}$ in fertile shoots. Midleaf cells $27.5-32.5 \times 25-30 \mu \mathrm{m}$, thin-walled, with triangle to concave moderate trigones; along margin 15-20 $\mu \mathrm{m}$, thinwalled, trigones concave to convex (adjacent to external wall), external wall slightly thickened. Dioicous. Androecia 3-4 pairs of bracts (different generation divided by 7-10 pairs of sterile leaves), 2-androus, stalk biseriate, ca. $75 \times 25 \mu \mathrm{m}$, body nearly spherical to shortly elliptic160-170 mcm in diameter; bracts similar to sterile leaves and not to strongly inflated in the base. Perianth 4-5-plicate in its upper $1 / 4$ of the length, suddenly contracted into not beaked mouth, exerted for $3 / 4$ of its length, mouth crenulate, middle perianth cells subisodiametric, 22.5-27.5 $\times 20-23 \mu \mathrm{m}$, thin-walled, with oil-bodies finely granulate, $4-6$ per cell, $4.5-6 \times 5-9 \mu \mathrm{m}$, irregularly elliptic, cells in basal part of the perianth shortly rectangular, 42-72 $\times 27.5-37.5 \mu \mathrm{m}$, thin-walled, with concave trigones, bistratose in lower half; female bracts erect spreading (not sheathing).

11) Jungermannia coniflora Schiffn. Reise der Gaselle in den Jahren 1874-76. 4 (Lebermoose): 10. 1889. 

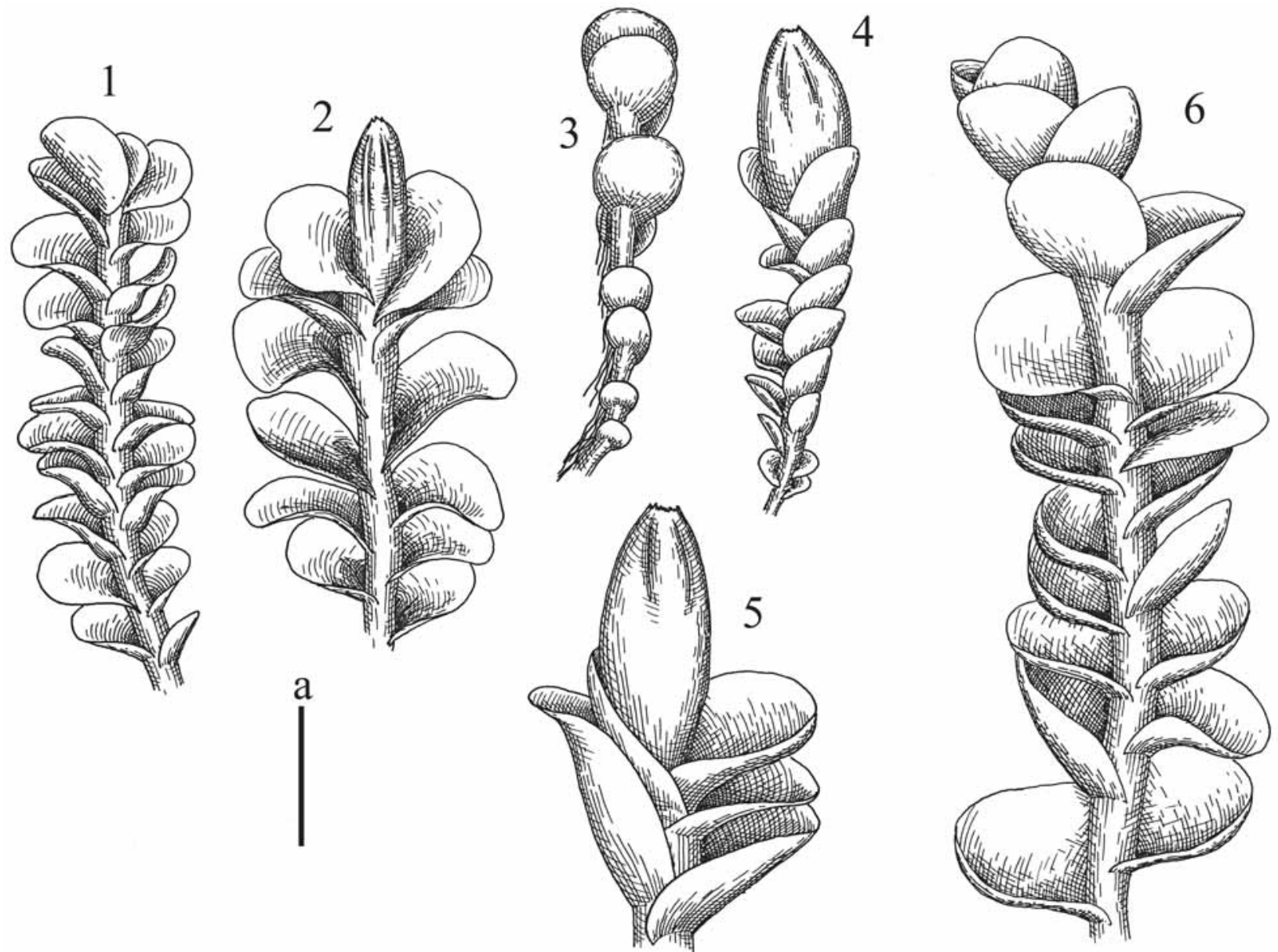

Fig. 5. Jungermannia dussiana Steph., holotype (G14457/00112189): 1 - plant habit; 2 - perianthous plant; Jungermannia duthiana Steph., holotype (G12915/00064473): 3 - plant habit, lateral view; 4-5 perianthous plants; Jungermannia exsertifolia Steph., holotype (G14574/00112197): 6 - plant habit. Scale: a - $1 \mathrm{~mm}$, for 1-5.

Isotypus: Kerguelen Island, Successful Harbor. XII.1874 Naumann G14494/00115333

Accepted name: Solenostoma coniflorum (Schiffn.) Steph. Sp. Hepat. 2: 59. 1901.

Description. Plants brownish to brown and yellowish-brown, seems erect to ascending, $1.0-1.5 \mathrm{~mm}$ wide and $7-15 \mathrm{~mm}$ long. Rhizoids brownish, obliquely spreading in unclear fascicles or separated. Stem brown, 190$250 \mu \mathrm{m}$ in diameter, slightly flexuous, freely branched as subfloral ventral innovations (becoming into normal branches). Leaves subtransversely inserted, shortly (for $1 / 4-1 / 3$ of stem width) decurrent dorsally and arcuately inserted and shortly (for 1/5-1/4 of stem width) decurrent ventrally, suborbicular, 700-750×700-820 $\mu \mathrm{m}$, obliquely spreading, concave-canaliculate. Midleaf cells thin-walled, $18.5-25.0 \times 16.0-22.5 \mu \mathrm{m}$, trigones moderate in size, convex, walls yellowish to brownish; cells along leaf margin 18-25 $\mu \mathrm{m}$, thin-walled, trigones moderate in size, convex, external wall very slightly thickened. Dioicous. Perianth clavate to clavate-cylindrical, $3(4)$-plicate in upper $2 / 3$ of its length, gradually narrowed to not beaked mouth, rarely mouth beaked, exerted for $1 /$ $2-2 / 3$ of its length; perigynium absent or very low. (Fig. 20: 9,10$)$.
12) Jungermannia danicola Gottsche ex Underw., Descriptive catalogue of the North American Hepaticae, North of Mexico. Bull. Illinois State Laboratory of Natural History 2: 107. 1883.

Isotypus: U.S.A. California, Mt. Dana. Bolander (No. 24) G $14436 / 00115337$

Accepted name: Solenostoma sphaerocarpum (Hook.) Steph., Sp. Hepat. 2: 61. 1901. = Jungermannia danicola Gottsche ex Underw. syn. nov. Descriptive catalogue of the North American Hepaticae, North of Mexico. Bull. Illinois State Laboratory of Natural History 2: 107. 1883.

Comment. The name was regarded as synonymous with Jungermannia scalariformis Nees (Naturgeschichte der Europäischen Lebermoose 2: 448. 1836.) by Váňa in 1970 (in litt.) and was synonymyzed later (Váňa, 1974c) with Jungermannia confertissima Nees (= Solenostoma confertissimum (Nees) Schljakov). Contrary to him, W.S. Hong (in litt.) regarded it as synonymous with Jungermannia sphaerocarpa Hook. (British Jungermanniae pl. 74. 1815.). Our data suggest the correctness of the latter point of view due to 1) absence of red coloration of shoots, 2) no rhizogenous cells in leaf lamina, 3) no distinct fascicle of rhizoids decurrent along the stem. 
13) Jungermannia decurrens Steph., Sp. Hepat. 6: 85. 1917.

Holotypus: Korea [Stephani (1917) incorrectly wrote "Japonia" probably due to the fact it was collected by U. Faurie, the noticeable collector mostly gathered plants in Japan]. Quelpaert (=Jeju Island) 1906 U. Faurie (No. 106) G00115348.

Accepted name: Solenostoma faurianum (Beauverd) Bakalin, Hepat. Fl. Phytogeogr. Kamchatka, 366. 2009.

Description. Plants erect to ascending, yellowishbrownish to reddish brown in exposed(?) shoots, 2.5-3.2 $\mathrm{mm}$ wide and 25-40 $\mathrm{mm}$ long. Rhizoids virtually absent to very few, purplish. Stem $320-400 \mu \mathrm{m}$ in diameter, not branched. Leaves subtransversely inserted, dorsally decurrent for ca. 1-3 stem width and ventrally decurrent for 1-2 stem width, flattened to slightly concave and slightly concave-canaliculate, commonly reddish near their bases and along leaf rims, rarely undulate at margin, obliquely spreading to slightly appressed to the stem, 1.5-1.7 $\times 2.0-2.2 \mathrm{~mm}$. Midleaf cells thin-walled, 18.0$37.5 \times 18.0-27.5 \mu \mathrm{m}$, with moderate in size, convex trigones, walls colorless, purplish to brownish; cells along leaf margin 15-19 $\mu \mathrm{m}$, thin-walled, with moderate in size, convex trigones, external wall thickened; leaf cuticle smooth throughout, with exception of lower 1/4-1/3 of its length, where become distinctly papillose-striolate. Dioicous. Androecia spicate, intercalary, with 5-6 pairs of bracts, bracts cupped, with narrow recurved margin. Perianth loosely 4-plicte in upper half, gradually narrowed to beaked (sometimes unclearly) mouth, upper part of the perianth brightly purple colored, perianth hidden within bracts or exerted for $1 / 5$ of its length (probably perianths are not mature in the specimen). (Fig. 4: 2).

Comment. The name (Jungermannia decurrens Steph.) has two earlier homonyms: Jungermannia decurrens Desv. (Observations sur les Plantes des Environs d'Angers 20. 1818.) and Jungermannia decurrens Reinw., Blume \& Nees (Nova Acta Phys.-Med. Acad. Caes. Leop.-Carol. Nat. Cur. 12: 206 [Hepat. Jav.]. 1825.). Due to this fact it was renamed as Jungermannia fauriana Beuaverd. ex Steph. (Sp. Hepat. 6: 571. 1924.) and later was transferred to Solenostoma by Bakalin (2009).

14) Jungermannia dussiana Steph. in Urban, Symb. Antil. 3: 276. 1902.

Holotypus: Martinique. VIII.1901. Duss (No. 569) G14457/00112189.

Accepted name: Plectocolea comata (Nees) S. Hatt., Bull. Tokyo Sci. Mus. 11: 38. 1944. (= Jungermannia dussiana Steph. in Urban Symb. Antil. 3: 276. 1902. syn. nov.)

Description. Plants prostrate to ascending, brownish to brownish-yellow, with purplish tint in ventral leaf base and pink to purplish tint in upper part of leaves near the apex, 1.5-2.7 mm wide, 5-12 $\mathrm{mm}$ long (male plants smaller). Rhizoids numerous, colorless to brownish and purplish, rigid, decurrent down the stem in unclear fas- cicles or obliquely spreading. Stem not or sparsely laterally (looks as depauperate ventral branches) branched, 200-250 $\mu \mathrm{m}$ in diameter. Leaves canaliculate to concavecanaliculate, in larger leaves with convex middle part and incurved margins; obliquely inserted, dorsally decurrent for $1 / 4-1 / 2$ of stem width, ventrally arcuately inserted, shortly (less than $1 / 4$ of stem width) decurrent, when flattened obliquely ovate to obliquely lingulate, ca. $600 \times 450-600 \mu \mathrm{m}$. Midleaf cells thin-walled, oblong, 50$87 \times 32-50 \mu \mathrm{m}$, trigones moderate to large, mostly convex, cuticle papillose; cells along leaf margin 25-31 $\mu \mathrm{m}$, thin- to slightly thick-walled, external wall noticeable thickened, cuticle verrucose (to coarsely verrucose). Dioicous. Androecia intercalary, with 6 and more pairs of bracts, male bracts canaliculate, strongly inflated in lower $1 / 3-1 / 2$ of the length. Perianth pluriplicate, with 5-6 main plicae, gradually narrowed to the mouth, conical, exerted for $1 / 5-1 / 3$ of its length; perigynium ca. $1 / 4$ of perianth length. (Fig. 5: 1, 2).

Comment. This name was synonymyzed with Jungermannia callithrix Lindenb et Gott. ${ }^{1}$ by Váňa (1974a) as a modification not different from common forms of $J$. callithrix. In my opinion, this is not quite correct. The plants in the type of $J$. dussiana differ from common forms of Plectocolea callithrix in more distant leaves which are always longer than wide (versus contiguous to subimbricate and enclosed one to another in P. callithrix, and mostly as long as wide). Additionally dorsal part of the leaf is commonly convex, and antical leaf margin narrowly recurved (that gives 'plagiochiloid' appearance); androecia are not terminal (versus terminal in $P$. callithrix). The listed features suggest Plectocolea comata (Nees) S. Hatt., rather than P. callithrix. Perhaps this is a separate taxon related to $P$. comata (different from typical forms of the latter in leaf apices coloration, not so strongly verrucose cuticle, geographical distribution, etc.), but due to limited material in the type specimen any conclusion would be premature.

15) Jungermannia duthiana Steph., Sp. Hepat. 2: 71. 1901.

Holotypus: Kashmir. Alt. 10000-11000 feet a. s. 1. 22.V.1892. J.F. Duthie G 12915/00064473.

Accepted name: Solenostoma duthianum (Steph.) C. Gao, Bryoflora of Xizang 495. 1985.

Description. Plants erect to ascending, yellowishbrownish, without red pigmentation. Rhizoids rather colorless to grayish, forming fascicles (sometimes unclear) decurrent down the stem, originated both from the stem and from leaf cells. Stem $150-170 \mu \mathrm{m}$ in diameter, not branched (rarely as ventral innovations). Leaves subtransversely to slightly obliquely inserted, decurrent dorsally for (1/4) $1 / 2-2 / 2$ of stem width, and ventrally up $1 / 2-4 / 2$ of stem width, concave to con-

\footnotetext{
1 - Plectocolea callithrix (Lindenb. et Gott.) Bakalin comb. nov. Basionym: Jungermannia callithrix Lindenb. \& Gott. in Gottsche, Lindenberg et Nees Syn. Hepat. 673. 1847.
} 
cave-canaliculate, obliquely spreading to almost imbricate and sheathing the stem, suborbicular to transversely elliptic, 600-900×700-900 $\mu \mathrm{m}$. Midleaf cells isodiametric to shortly oblong, 26-36×21-28 $\mu \mathrm{m}$, thinwalled, trigones moderate in size, concave, cuticle smooth; cells along leaf margin 25-33 $\mu \mathrm{m}$, thin-walled, with external wall thickened, trigones moderate, concave to convex. Paroicous. Androecia with 3-4 pairs of bracts below female bracts. Perianth 3(4)-plicate in its almost whole extent, slightly rhizogenous in lower $2 / 3$, bistratose in lower half or even upward; gradually narrowed to the hardly beaked mouth; clavate to cylindrical-clavate, exerted for $3 / 4-4 / 5$ of its length; perigynium up to $1 / 4$ of perianth. Spores papillose, brown, $21-24 \mu \mathrm{m}$ in diameter. Elaters ca. $150 \times 8.8 \mu \mathrm{m}$, bispiral, with long (ca. $25 \mu \mathrm{m}$ ) homogenous ends. (Fig. 5: 3-5).

Comment. This name was synonymized with $S$. confertissimum (Nees) Schljakov by Ván̆a (1972b), but differs from the latter in bistratose perianth, absence of red or purple pigmentation, and also, probably, in habitat (the type specimen was collected on decaying wood - the habitat unsuitable for true $S$. confertissimum). Thus, in my opinion $S$. duthianum deserves the species rank.

16) Jungermannia exsertifolia Steph., Sp. Hepat. 6: 86. 1917.

Holotypus: Japan. Sendai 19.V.1907 U. Jishiba (No. 153) G14574/00112197.

Accepted name: Jungermannia exsertifolia Steph., Sp. Hepat. 6: 86. 1917.

Description. Plants erect to ascending, in loose patches, greenish-brown, 2-2.5 mm wide, 10-15 $\mathrm{mm}$ long. Rhizoids few, colorless to brownish, separated or rarely in unclear mat. Stem 120-160 $\mu \mathrm{m}$ wide, not or rarely intercalary branched. Leaves ovate, $900-1200 \times 750-1100$ $\mu \mathrm{m}$, obliquely inserted, obliquely spreading laterally, dorsally subtransversely inserted (rarely obliquely), ventrally insertion line loosely arcuate, not or barely decurrent in the both sides. Midleaf cells thin-walled, oblong, 25.0$39.0 \times 21.0-25.0 \mu \mathrm{m}$, trigones small, concave, walls rusty brownish, cuticle distinctly striolate-papillose. Dioicous. Perianth terminal, clavate, loosely to distinctly plicate in upper $1 / 3-1 / 4$, ca. $2.5 \times 1.0 \mathrm{~mm}$, exerted for $3 / 4$ of the perianth length; perigynium virtually absent. (Fig. 5: 6)

17) Jungermannia flavorevoluta Váňa, J. Hattori Bot. Lab. 36: 63. 1972[1973].

Isotypus: India. Sikkim. 9000 ped. J.D. Hooker G11168/00115180.

Accepted name: Solenostoma flavorevolutum (Ván̆a) Váňa \& D.G. Long, Nova Hedwigia 89: 501. 2009.

Description. Plants erect in dense (if possible to suggest) patches, yellowish-brownish, without red pigmentation, 1.5-2.25 mm wide and 10-18 $\mathrm{mm}$ long. Stem $150-200 \mu \mathrm{m}$ in diameter, but looks wider due to thick and dense rhizoids fascicle closely attached to the stem, brownish, sparsely laterally branched (also as subfloral innovations). Rhizoids very numerous, originated from leaf lamina and decurrent down the stem in thick fascicle of $200 \mu \mathrm{m}$ in diameter or even wider, brownish. Leaves obliquely spreading, with narrowly revolute margin, concave-canaliculate, transversely to subtransversely inserted, decurrent dorsally for $1 / 2-2 / 2$ of stem width, ventrally decurrent for $2 / 3-4 / 3$ of stem width, contiguous to (more frequently) imbricate and enclosed one to another, obliquely transversely elliptic when flattened in the slide, 875-950×1250-1375 $\mu \mathrm{m}$. Midleaf cells 15.0-22.5×12.5$16.5 \mu \mathrm{m}$, thin-walled, with moderate to large, convex trigones, cuticle smooth; cells along leaf margin commonly with discolored walls, 8.7-15.0 $\mu \mathrm{m}$, unequally thickened, trigones large, convex, sometimes confluent, external wall thickened, cuticle smooth. Dioicous? Perianth fusiform, pluriplicate, ca. $2750 \times 1100 \mu \mathrm{m}$, densely rhizogenous, not only outside, but inside too, exerted for 1/6-1/4 of its length; perigynium ca. $1 / 5$ of perianth length; female bracts similar to large leaves, closely sheathing perianth, not or loosely spreading in upper 1/ 4. (Fig. 27: 8-17).

Comment. The specimen was named in the herbarium as Solenostoma clavellatum Mitt. ex Steph. (Sp. Hepat. 2: 53. 1901.) and was regarded as lectotype of $S$. clavellatum by R. Grolle (1965). Later Váňa (1972b) showed the lectotypification by Grolle was incorrect and selected another lectotype of Solenostoma clavellatum from BM. He treated the specimen from G (G11168/ 00115180) as the isotype of newly described by him Jungermannia flavorevoluta.

18) Nardia fusiformis Steph., Bull. Herb. Boissier [Hepaticae Japonicae] 5: 99. 1897. (= Jungermannia fusiformis (Steph.) Steph., Sp. Hepat. 2: 77. 1901.)

Holotypus: Japan. Yezo, Otaru. 28.XII.1885. U. Faurie (No. 88) G00112194.

Accepted name: Solenostoma fusiforme (Steph.) R. M. Schust., Hepat. Anth. North Amer. 2: 944. 1969.

Description. Plants pallid, more or less pellucid, yellowish-brownish, prostrate, rarely ascending in perianthous plants, forming loose mats, $0.3-1.0 \mathrm{~mm}$ wide and $5-10 \mathrm{~mm}$ long, laterally flattened. Stem $75-250 \mu \mathrm{m}$ in diameter, slightly wider near perianth, not branched, yellowish-brownish. Rhizoids sparse to nearly absent or dense and numerous, originated throughout ventral side of stem, but commonly concentrated near ventral leaf bases, grayish to pale brownish. Leaves lax, soft, commonly undulate at margin, obliquely to very obliquely (rarely in periantous plants subtransversely) inserted, barely or up to $1 / 3$ of stem width decurrent dorsally and subtransversely to loosely arcuately inserted ventrally, where not or barely decurrent, distant, to (rarer, in perianthous plants only) contiguous, obliquely spreading and subhorizontally oriented, in perianthous plants sometimes appressed to the stem and emarginate near apex, large leaves crispate along margin, in general outline leaves 


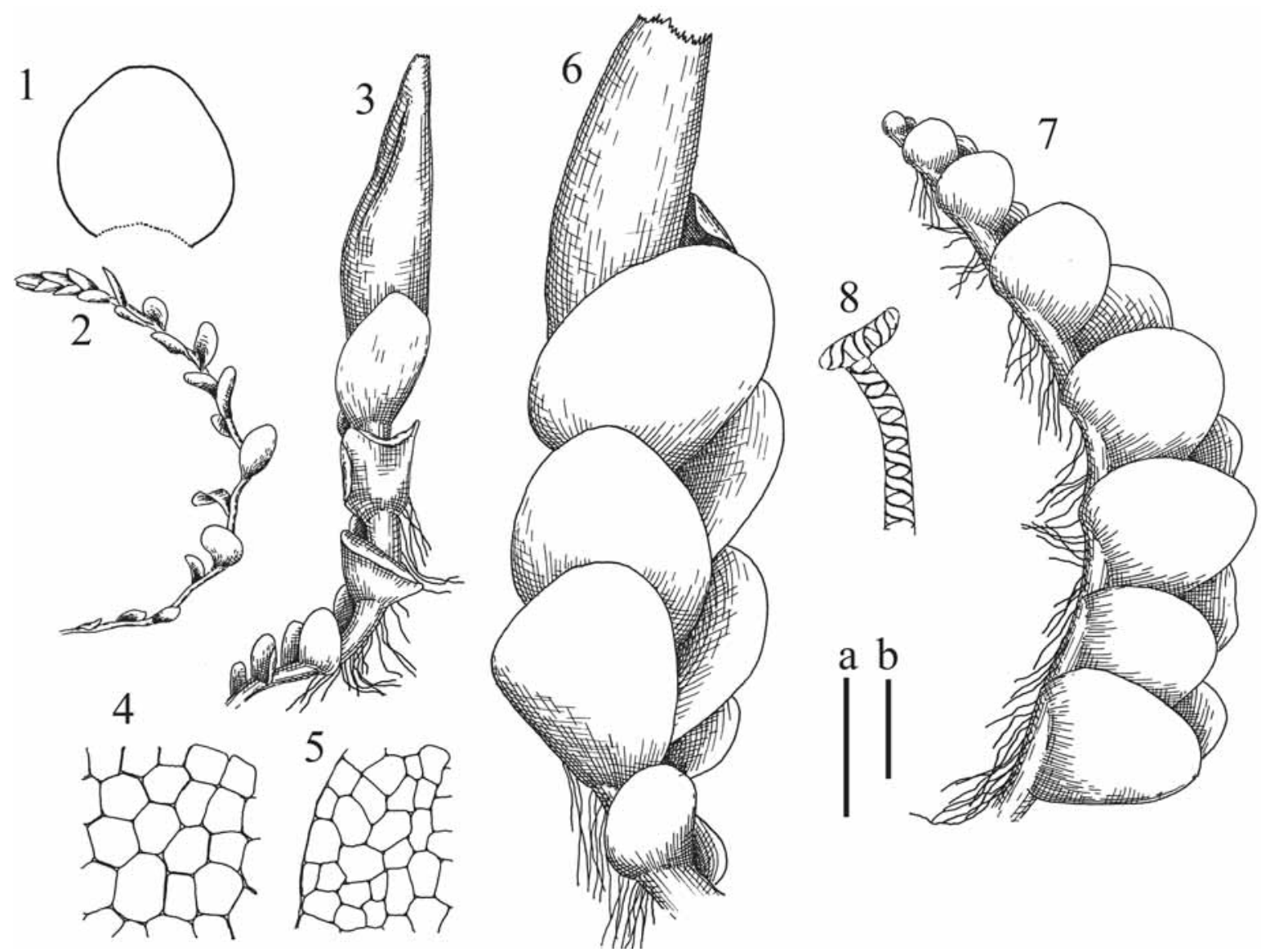

Fig. 6. Nardia fusiformis Steph., holotype (G00112194): 1 - leaf; 2 - sterile depauperate plant; 3 - perianthous plant; 4 midleaf cells; 5 - cells along leaf margin; Jungermannia gollanii Steph., lectotype (G10921/00112200): 6 - perianthous plant; 7 - sterile plant, lateral view; 8 - fragment of elater. Scales: $\mathrm{a}-1 \mathrm{~mm}$, for $2,3,6,7 ; \mathrm{b}-100 \mu \mathrm{m}$, for 4, 5; a - 500 $\mu \mathrm{m}$, for $1 ; \mathrm{b}-50$ $\mu \mathrm{m}$, for 8 .

ovate to suborbicular, 450-800×350-925 $\mu \mathrm{m}$. Midleaf cells subisodiametric, mostly penta- to hexagonal, 31.0$42.0 \times 29.0-42.0 \mu \mathrm{m}$, thin-walled, trigones small, mostly concave, cuticle smooth; cells along leaf margin 25.0$37.5 \mu \mathrm{m}$, thin-walled, trigones small, concave, cuticle smooth. Dioicous? Perianth fusiform, not or shallowly 3 -plicate, gradually narrowed to not beaked mouth, rarely loosely turbinate near mouth, exerted for $2 / 3-3 / 4$ of its length, composed by elongate, thin-walled cells; perigynium ca. 1/4-1/5 of perianth length, with 1 pair of bracts, loosely rhizogenous ventrally; female bracts similar to large leaves, undulate and shallowly crispate at margin. (Fig. 6: 1-5).

19) Jungermannia gollanii Steph., Sp. Hepat. 6: 86. 1917.

Lectotypus (designated by Amakawa, 1966): India. Dehra Dun, Mohand Pass, Siwalik Range, on wet rocks, 1600 ped. G10921/00112200.

Accepted name: Plectocolea gollanii (Steph.) Bakalin comb. nov. Basionym: Jungermannia gollanii Steph., Sp. Hepat. 6: 86. 1917.

Description. Plants pale greenish-brownish, prostrate to ascending, forming loose mats, mostly laterally compressed, 2.0-2.75 mm wide and 10-15 mm long. Rhiz- oids rather numerous, erect to (rarer) obliquely spreading, colorless to brownish, attached plants to the substratum. Stem brownish, not branched (even as subfloral innovations), 200-250 $\mu \mathrm{m}$ in diameter. Leaves very obliquely inserted, flattened to very loosely concave or slightly convex, dorsally not or barely decurrent, ventrally arcuately inserted (sometimes with auriculate leaf base), ovate to obliquely ovate, $1750-2500 \times 1500-2000$ $\mu \mathrm{m}$. Midleaf cells subisodiametric to oblong, $50-75 \times 31-$ $44 \mu \mathrm{m}$, thin-walled, trigones vestigial to very small, cuticle virtually sooth; cells in leaf margin commonly elongate along margin, 50-69 $\mu \mathrm{m}$, thin-walled, trigones small, concave. Dioicous? Perianth almost cylindrical, not or loosely placate, ca. $3.0 \times 1.0 \mathrm{~mm}$, only slightly narrowed to the mouth, exerted for $1 / 2-2 / 3$ of its length; mouth crenulate due to protrudent ob-pyriform cells with slightly thickened walls; cells in the perianth middle 112$200 \times 37-50 \mu \mathrm{m}$, thin-walled, with vestigial trigones, bistratose in lower $1 / 3$ and cell cuticle striolate at that area; perigynium virtually absent; female bracts similar to leaves, but commonly larger and slightly emarginate at apex. Elaters sometimes branched, bispiral. (Fig. 6: 6-8).

Comment. Contrary to Amakawa (1966) and Váňa (1972a), who placed this species to subg. Luridae Spruce 
ex S.W. Arnell (= Jungermannia subg. Jungermannia L., auct. non Amakawa 1966, etc.; = Jungermannia s str.) I refer it to Plectocolea due to the following features: 1) mostly unistratose perianth, 2) perianth composed by elongate cells, 3 ) leaf cells are large (up to 75 $\mu \mathrm{m}$ long, which is unsuitable for taxa of Jungermannia s. str.). The main reason why this species was put in Jungermannia by aforementioned authors is the absence of perigynium, but I do not consider this feature to be very valuable in this case, because several species of Plectocolea have perigynium very low to desired. One of possibly related species, Plectocolea glauca (Amak.) Bakalin comb. nov. (Basionym: Jungermannia glauca Amakawa J. Hattori Bot. Lab. 29: 256, 1966), also has no perigynium.

20) Jungermannia grossitexta Steph., Sp. Hepat. 6: 87. 1917.

Holotypus: Japan. 1907. U. Jishiba. G 14484‘112193.

Accepted name: Plectocolea grossitexta (Steph.) S. Hatt., Bull. Tokyo Sci. Museum 11: 38.1944.

Description. Plants prostrate to ascending, pale greenish-brownish, with brown-purple colored perianth tips and purplish tint near apices of female bracts, 1.75-3.0 $\mathrm{mm}$ wide and 10-15 mm long, dorsiventrally flattened, more or less soft. Rhizoids rather numerous, erect to obliquely spreading in unclear fascicles, colorless to brownish purplish (only those originated from perigynium or area near to it). Stem 175-325 $\mu \mathrm{m}$ in diameter (wider near perigynium), not branched, slightly to moderately flexuous. Leaves undulate at margin, lax, contiguous to (rarer) distant, very obliquely inserted, dorsally decurrent for $2 / 3-5 / 3$ of stem width, ventrally subtransversely to arcuately inserted, not or shortly decurrent, loosely concave to loosely canaliculate, obliquely laterally spreading, loosely sheathing the stem near base; 1130$1250 \times 875-1500$ (1:0.7-1.3), obliquely ovate to obliquely reniform, retuse at apex. Midleaf cells strongly collapsed (so it is difficult to see features), subisodiametric, ca. $25-50 \mu \mathrm{m}$ in diameter, thin-walled, trigones small, concave, cuticle smooth; cells along leaf margin 33-44 $\mu \mathrm{m}$, thin-walled, trigones small, concave, cuticle smooth. Dioicous? Perianth conical, ca. $2 \times 1 \mathrm{~mm}$, pluriplicate, with 5-6 main plicae, distinctly turbinate at the mouth, exerted for $1 / 2-2 / 3$ of its length, composed by very elongate cells; perigynium ca. $1 / 2-2 / 3$ of perianth length, rhizogenous ventrally; female bracts sheathing the perigynium and erect spreading above, undulate at margin. (Fig. 7: 1).

Comment. The taxon was treated as distinct species by Amakawa (1960), but his interpretation has certainly nothing to do with holotype specimen, as it was showed by Váňa (1972a) and belongs to another species (Jungermannia shimizuana Váňa, J. Hattori Bot. Lab. 35: 315. 1972 = Solenostoma shimizuanum (Váňa) Váňa, Hentschel \& J. Heinrichs, Cryptogamie Bryologie 31(2): 138. 2010.). In the same paper Ván̆a (1972a) synonymyzed Jungermannia grossitexta (= Plectocolea gros- sitexta (Steph.) S. Hatt.) with J. torticalyx Steph. (=Plectocolea torticalyx (Steph.) S. Hatt.). Unfortunately he did not provide the reasons for this synonymyzation. In my opinion, Plectocolea grossitexta is a rather distinct species, although allied to $P$. torticalyx. Contrary to the latter, Plectocolea grossitexta is characterized by prostrate to ascending growth form (versus mostly erect), colorless to brownish rhizoids (versus almost uniformly purple), pale pigmentation (versus mostly deep green to brownish green) with common presence of pinkish or purplish tints (versus purplish pigmentation virtually absent), perianth exerted for $2 / 5-2 / 3$ of its length (versus perianth exerted not more than $1 / 3$ of its length), perigynium shorter than perianth (versus perigynium 1.0 2.0 times longer than perianth) and leaves commonly longer than wide, obliquely inserted and oriented (versus leaves uniformly wider than long, subtransversely or rarely obliquely inserted and rather subtransversely oriented).

21) Jungermannia hirticalyx Steph., Sp. Hepat. 6: 87. 1917.

Holotypus: Nova Caledonia. Franc (No. 106 p.p. by Theriot) G14462/00112202.

Accepted name: Plectocolea montana (Steph.) Bakalin comb. nov. Basionym: Nardia montana Steph., Hedwigia 28: 164. 1889.

Description. Plants prostrate, dorsiventrally flattened, greenish, pale greenish, greenish-brownish, in loose mats (0.75)1.0-1.5(1.75) mm wide and 5-10 mm long. Rhizoids numerous, colorless to purplish, obliquely to erect spreading, rarely decurrent down the stem, but not forming the fascicle. Stem 125-200 $\mu \mathrm{m}$ in diameter, not branched. Leaves contiguous, very obliquely inserted, dorsally shortly (up 1/2 of stem width) decurrent, ventrally arcuately to subtransversely inserted, not or barely decurrent, rarely, in perianthous large plants decurrent up to $1 / 2$ of stem width, lax, commonly undulate at the margin, slightly canaliculate to concave-canaliculate, ovate to reniform, $500-750 \times 400-800 \mu \mathrm{m}$, obliquely spreading. Midleaf cells subisodiametric to oblong, 25.0 $44.0 \times 25.0-34.0 \mu \mathrm{m}$, thin-walled, trigones moderate, nearly triangle to slightly concave or convex, cuticle distinctly papillose; leaf cells along margin $22.0-31.5 \mu \mathrm{m}$, with noticeable equally thickened walls, trigones rather small, concave, cuticle distinctly verrucose. Dioicous. Androecia intercalary, with 6-7 pairs of bracts, bracts strongly inflated in lower half and recurved away of the stem along margin (in upper $1 / 3$ of leaf). Perianth rather conical, pluriplicate (with 3-4 main plicae), cells in perianth middle noticeable elongate; perigynium virtually absent or up to $1 / 4$ of perianth length; female bracts reniform, undulate, retuse at apex, sheathing perianth in lower half. (Fig. 7: 2-5).

Comment. See explanations under Jungermannia wattsiana Steph. and Solenostoma australe Steph. 

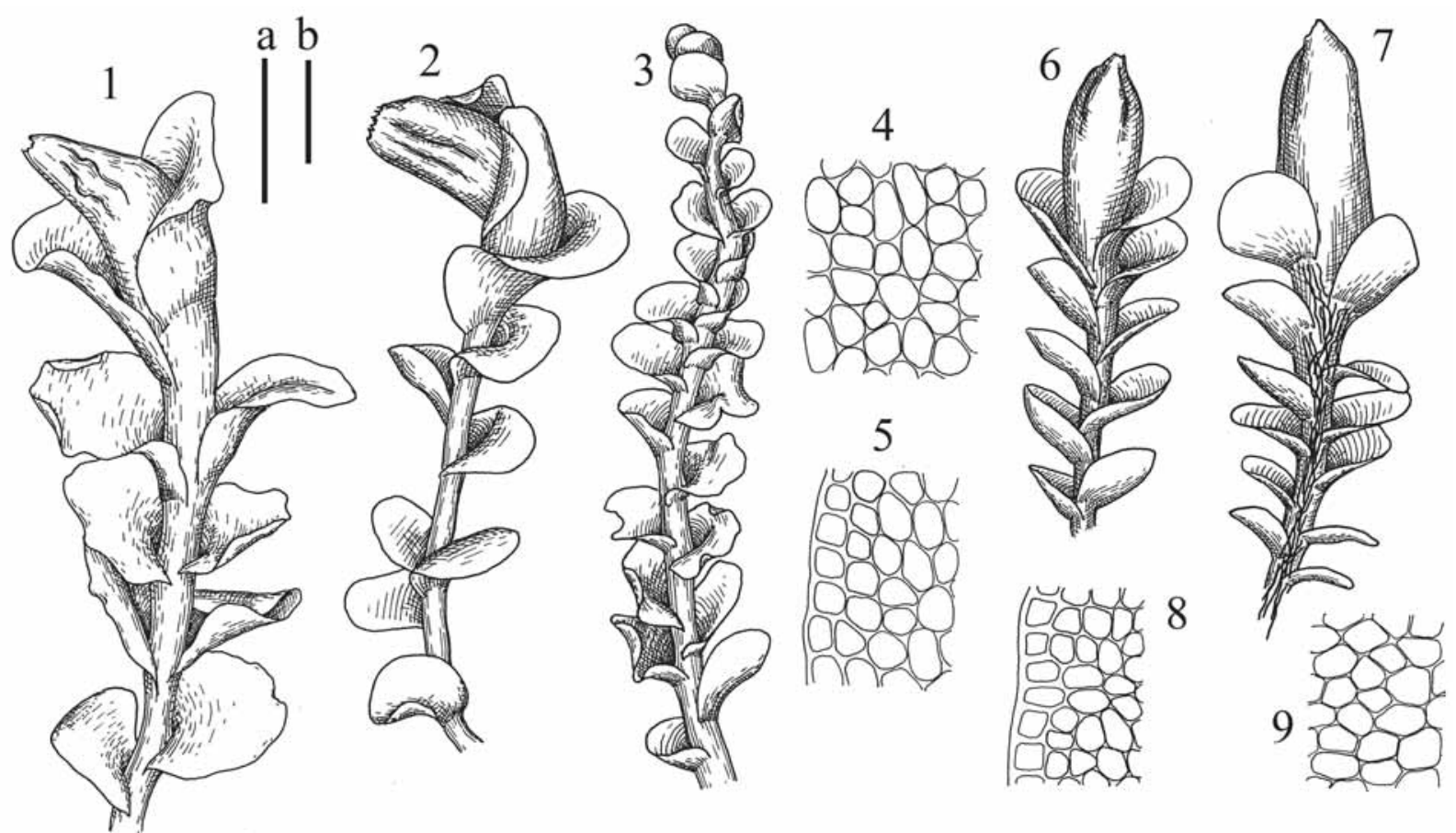

Fig. 7. Jungermannia grossitexta Steph., holotype, (G14484‘112193): 1 - perianthous plant; Jungermannia hirticalyx Steph., holotype (G14462/00112202): 2 - perianthous plant; 3 - male plant; 4 - midleaf cells; 5 - cells along leaf margin; Jungermannia hyalina Lyell. var. heteromorpha Gott. et Rabenh., isotype (G00115357): 6 - perianthous plant; 7 - perianthous plant - ventral view; 8 - cells along leaf margin, 9 - midleaf cells. Scales: a - $1 \mathrm{~mm}$, for $1-3,6,7 ; \mathrm{b}-100 \mu \mathrm{m}$, for 4, 5, 8, 9 .

22) Jungermannia hyalina Lyell. var. heteromorpha Gott. et Rabenh., Hepaticae Europeae, No. 628. 1877.

Isotypus: Germany. Salem. 14.X.1875. Jack G00115357.

Accepted name: Solenostoma gracillimum var. heteromorpha (Gott. et Rabenh.) Bakalin comb. nov. Basionym: Jungermannia hyalina Lyell. var. heteromorpha Gott. et Rabenh., Hepaticae Europeae, No. 628. 1877.

Comment. Váňa (1974c) regarded this name as mod. pachyderma-colorata of Jungermannia gracillima Sm. (= Solenostoma gracillimum (Sm.) R.M. Schust.), characterized by larger and slightly undulate leaves, leaf cells with somewhat thickened walls, not obviously enlarged leaf rim cells and almost fusiform perianth with beaked mouth. In the studied specimen, I found plants with following characters: (some of them reported by Váňa, 1.c.): 1 - leaf border with unequally thickened cell walls, $2-$ presence of moderate trigones in leaf cells, 3 - rather erect growth form, 4 - no red pigmentation (plants are yellowish-greenish), 5 - perigynium ca. $1 / 4$ of perianth length, 6 - comparatively large, fusiform and only loosely plicate perianth. The features \#1 and 2 suggest Solenostoma gracillimum f. crenulatum (Mitt.) R.M. Schust., while \#3-6- not typical for any forms. I prefer to regard var. heteromorpha as a separate variety of $S$. gracillimum. (Fig. 7: 6-9).

23) Jungermannia inundata Hook. f. \& Taylor, London J. Bot. 3: 559. 1844.

Isotypus: New Zealand. Hooker. G 14447/00115362.
Accepted name: Solenostoma inundatum (Hook. f. \& Taylor) Mitt. ex Steph., Bull. Herb. Boissier, sér. 2, 1: 490. 1901.

Description. Plant green-brown to olive-brown, rather ascending (if tentatively suggest so), $0.23-0.5 \mathrm{~mm}$ wide and $3-5 \mathrm{~mm}$ long. Rhizoids sparse, obliquely spreading, colorless to grayish. Leaves contiguous, obliquely inserted, not or shortly decurrent dorsally and subtransversely inserted ventrally, concave, $175-325 \times 275-500 \mu \mathrm{m}$. Midleaf cells strongly collapsed (that is very difficult to see), ca $17.5-24.0 \mu \mathrm{m}$ in diameter. Dioicous? Perianth clavate, 4-plicate at the upper $1 / 3$, bistratose in lower half, gradually narrowed to not beaked mouth; perigynium virtually absent. (Fig. 8: 1,2).

Comment. Only a few plants are present in the specimen.

24) Jungermannia macrocarpa Steph., Sp. Hepat. 6: 87. 1917. (= Aplozia macrocarpa Schiffn. in litt., 1902).

Holotypus: India. Darjeeling (Sikkim), "sous la galee blanche" $2135 \mathrm{~m}$ a.s.1. 31.XII.1899. R. Decoly G10924/00115185.

Accepted name: Solenostoma macrocarpum (Steph.) Váňa \& D.G. Long, Nova Hedwigia 89: 504. 2009.

Description. Plants rather erect (if possible to suggest so, material is in very bad condition), greenishbrownish to yellowish-brownish, from $2.5 \mathrm{~mm}$ wide in sterile plants to $4.5 \mathrm{~mm}$ wide in perianthous ones, $5-15 \mathrm{~mm}$ long. Stem $200-450 \mu \mathrm{m}$ in diameter (wider near the perianth), not branched, with the exception of lateral subfloral innovations. Rhizoids numer- 


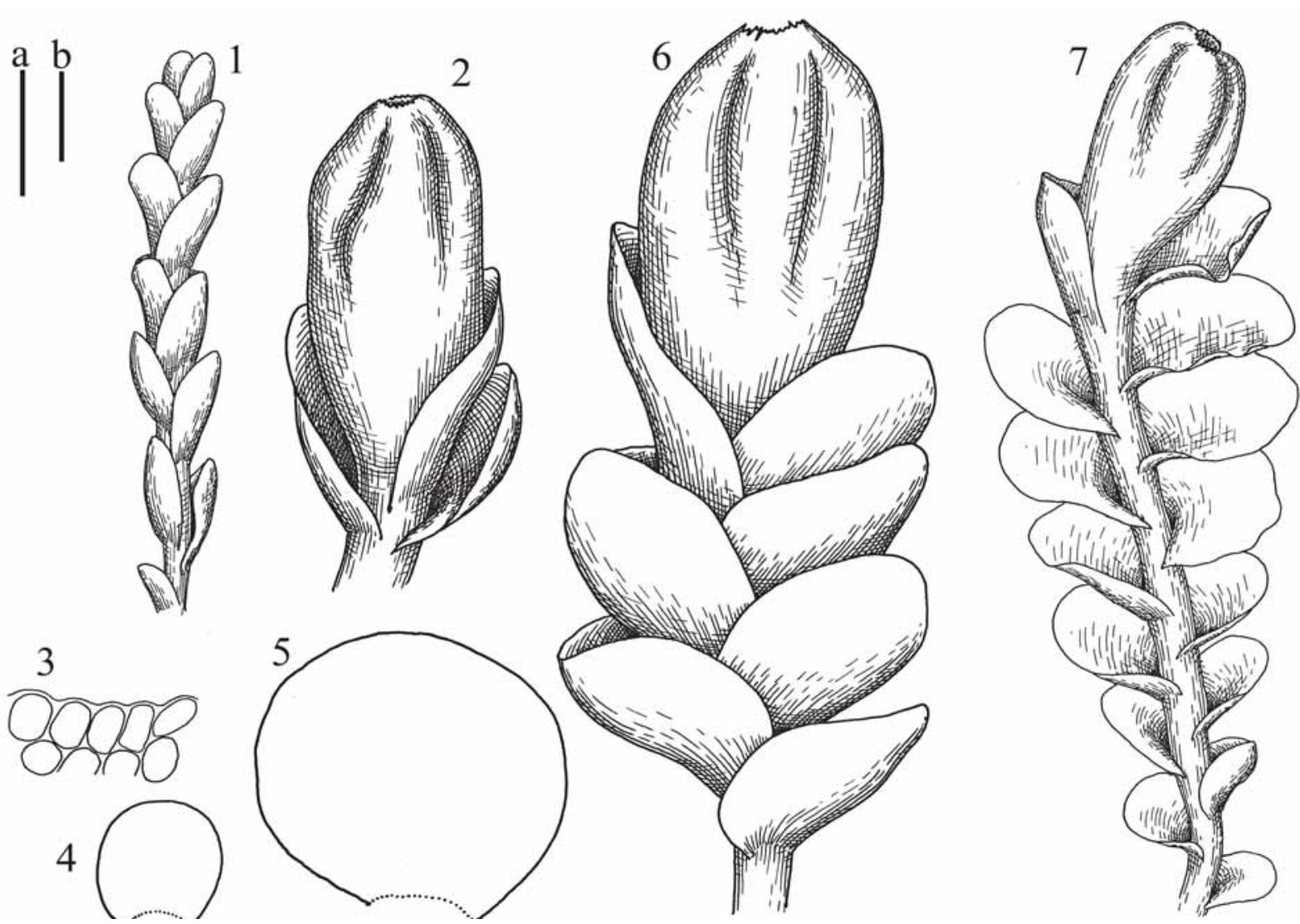

Fig. 8. Jungermannia inundata Hook. f. \& Taylor, isotype (G14447/00115362): 1 - plant habit; 2 - upper part of perianthous plant; Jungermannia macrocarpa Steph., holotype (G10924/00115185): 3 - perianth mouth; 4, 5 - leaves; 6 - perianthous plant; Jungermannia riparia Tayl. var. major Gottsche et Rabenh., lectotype (G00114367): 7 - perianthous plant. Scales: a - $1 \mathrm{~mm}$, for $4-6$; $\mathrm{b}-100 \mu \mathrm{m}$, for 3 ; $\mathrm{a}-500 \mu \mathrm{m}$, for 1,2 ; a $-590 \mu \mathrm{m}$, for 7 .

ous, grayish-brownish to brown, obliquely spreading (separated or in unclear fascicles), but commonly forming thick mat under stem and unite plants in the patches one to another. Leaves mostly strongly undulate at margin (with the exception of small sterile plants), loosely concave, dorsally decurrent for $1 / 2$ $3 / 4$ of stem width, ventrally subtransversely to arcuately inserted, not decurrent, suborbicular to obliquely transversely elliptic, $1100-2750 \times 1250-3250 \mu \mathrm{m}$, contiguous to subimbricate (then enclosed one to another), large leaves sometimes bistratose in lower $1 /$ 4. Midleaf cells oblong, $50-75 \times 25-37 \mu \mathrm{m}$, thinwalled, trigones small, concave, cuticle smooth; cells along leaf margin 25-37 $\mu \mathrm{m}$, thin-walled, trigones moderate in size, convex, external wall thickened, cuticle virtually smooth. Dioicous? Perianth ca. $4.5 \times 2.25 \mathrm{~mm}, 5-6$-plicate (plicae sometimes undulate) in upper half, suddenly contracted to not beaked mouth, exerted for $1 / 2$ of the length, cylindrical, perianth upper $1 / 3$ unistratose, middle third bistratose and lower third 3-4-stratose, cells in the perianth middle oblong, 50.0-75.0 $\times 31.2-37.5 \mu \mathrm{m}$, thinwalled, trigones small to moderate in size, concave, cells in upper part of the perianth isodiametric, trigones moderate in size, concave, perianth mouth crenulate; perigynium absent or less than $1 / 6$ of perianth length; female bracts similar to large leaves. Spores papillose, brown-rusty, $13.7-15.0 \mu \mathrm{m}$ in diameter (Fig. 8: 3-6).

Comment. My description strikingly differs from the description given by Amakawa (1967) in many traits, including plant size, color, perianth and leaves dimensions. At the other hand, original description by Stephani (1917) is well coinciding with my observations and supports the appropriateness of the epithet "macrocarpa" due to remarkably large perianth. The discrepancies with Amakawa description are therefore difficult to understand. Unfortunately Amakawa (1967) did not cite herbarium accession number for the collection he studied, although the label data provided by him are identical with my own.

25) Jungermannia marcescens Mitt., J. Proc. Linn. Soc., Bot. 5: 91.1861.

Isotypus: Nepal (“In Himalayae orient."), reg. temp. 11000 ped. J.D. Hooker (No. 1316) G 14835/00115162.

Accepted name: Solenostoma marcescens (Mitt.) Bakalin, Polish Bot. J. 58(1): 139. 2013.

Comment. a) The material is very poor, but in all ways is identical with previously studied and discussed in detail type collection from NY (Bakalin, 2013). 

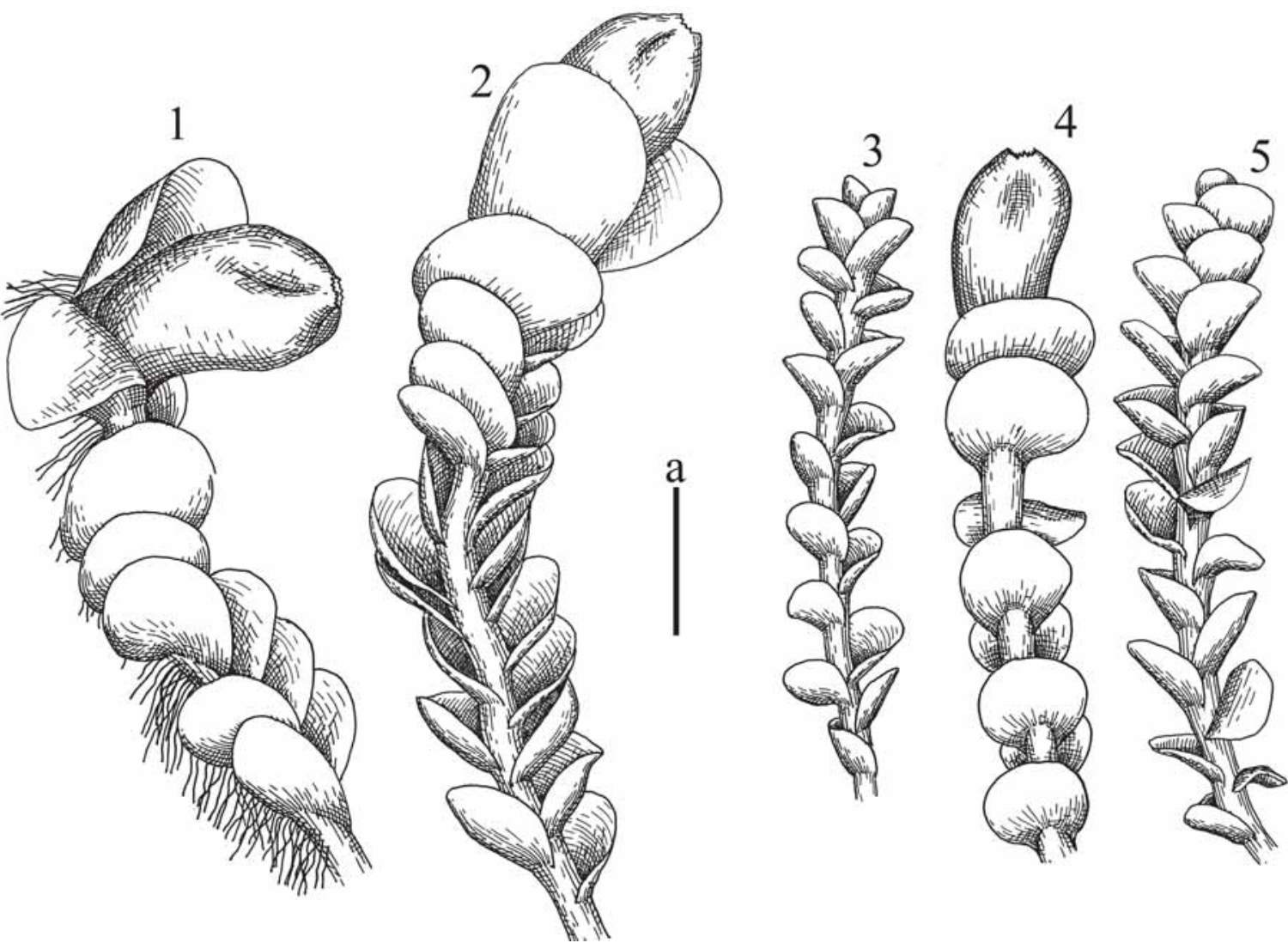

Fig. 9. Jungermannia mieheana Steph., holotype (G524/00112192): 1, 2 - perianthous plants; Jungermannia mildbraedii Steph., lectotype (G14300/00045331): 3, 5 - plant habit; 4 - perianthous plant. Scale: a - $1 \mathrm{~mm}$, for 1-5.

b) Bakalin (2013) discussed in details differences between S. marcescens and S. sanguinolentum (Griff.) Steph. and suggested to treat the former as a species distinct from S. sanguinolentum. The main differences were found in: 1) inflorescence type (paroicous in S. marcescens, but dioicous in S. sanguinolentum, 2) bistratose versus unistratose perianth at its middle part, 3) perianth size $(1.5 \mathrm{~mm}$ long versus $6 \mathrm{~mm}$ long), 4) yellowish to brownish versus light to deep pink coloration, 5) pachydermous versus leptodermous leaf cell structure. Shortly after appearance of this paper (l.c.), Váňa et al. (2013) suggested Bakalin's point of view is incorrect and two names should be regarded as synonyms, as the mentioned features are unstable. Indeed, if take each feature individually, the variability will be found in different groups (to affirm their considerations concerning inflorescence type, Váňa et al. (1.c.) involved an example of Lophoziopsis propagulifera, rather far distant genus from Solenostoma). Contrary, when I argued specific status for $S$. marcescens, I used a combination of features, not a single one. It is unclear for me how plants of supposedly the same species are able to develop only yellowish brownish pigmentation in pachydermous phenotypes, while more lax with leptodermous cells acquire a deep pink pigmentation. Also it seems strange why plants with the former combination of characters develop perianths up to 5 times longer than those of the latter. Therefore, I prefer to refrain from adopting Váňa et al. (2013) suggestion.
26) Jungermannia mieheana Steph., Sp. Hepat. 6: 88. 1917.

Holotypus: Java. Salak. 1909. Miehe G524/00112192.

Accepted name: Solenostoma bauerii (Schiffn.) Steph., Sp. Hepat. 2: 57. 1901.

Description. Plants prostrate, rarely ascending at the tips, pale greenish to brownish and pale yellowish-brownish, $1.5-2.0 \mathrm{~mm}$ wide, $10-15 \mathrm{~mm}$ long. Rhizoids numerous, colorless to grayish, erect spreading in unclear fascicles or forming mat in ventral side of stem, loosely attached plants to the substratum. Stem $300-400 \mu \mathrm{m}$ in diameter, not branched, even as subfloral innovations. Leaves lax, contiguous to subimbricate, loosely concave, sometimes undulate at margin, barely or up to $1 / 2$ of stem width decurrent dorsally, arcuate inserted ventrally, where not decurrent, obliquely spreading to loosely laterally appressed to the stem, transversely elliptic to reniform, larger leaves retuse at the apex, $1000-1500 \times 1500-2100$ $\mu \mathrm{m}$. Midleaf cells 50.0-62.5×31.0-50.0 $\mu \mathrm{m}$, thin-walled, with moderate in size, convex trigones, cuticle smooth; cells along leaf margin 31.2-50.0 $\mu \mathrm{m}$, thin-walled, with slightly thickened external wall, trigones moderate in size, convex. Dioicous? Perianth 4(5)-plicate in upper 3/4 of its length, ellipsoidal, gradually narrowed to widely and obscurely beaked mouth, exerted for $1 / 2-2 / 3$ of its length; perigynium absent. (Fig. 9: 1, 2).

Comment. Váňa (1974d) synonymyzed Jungerman- 

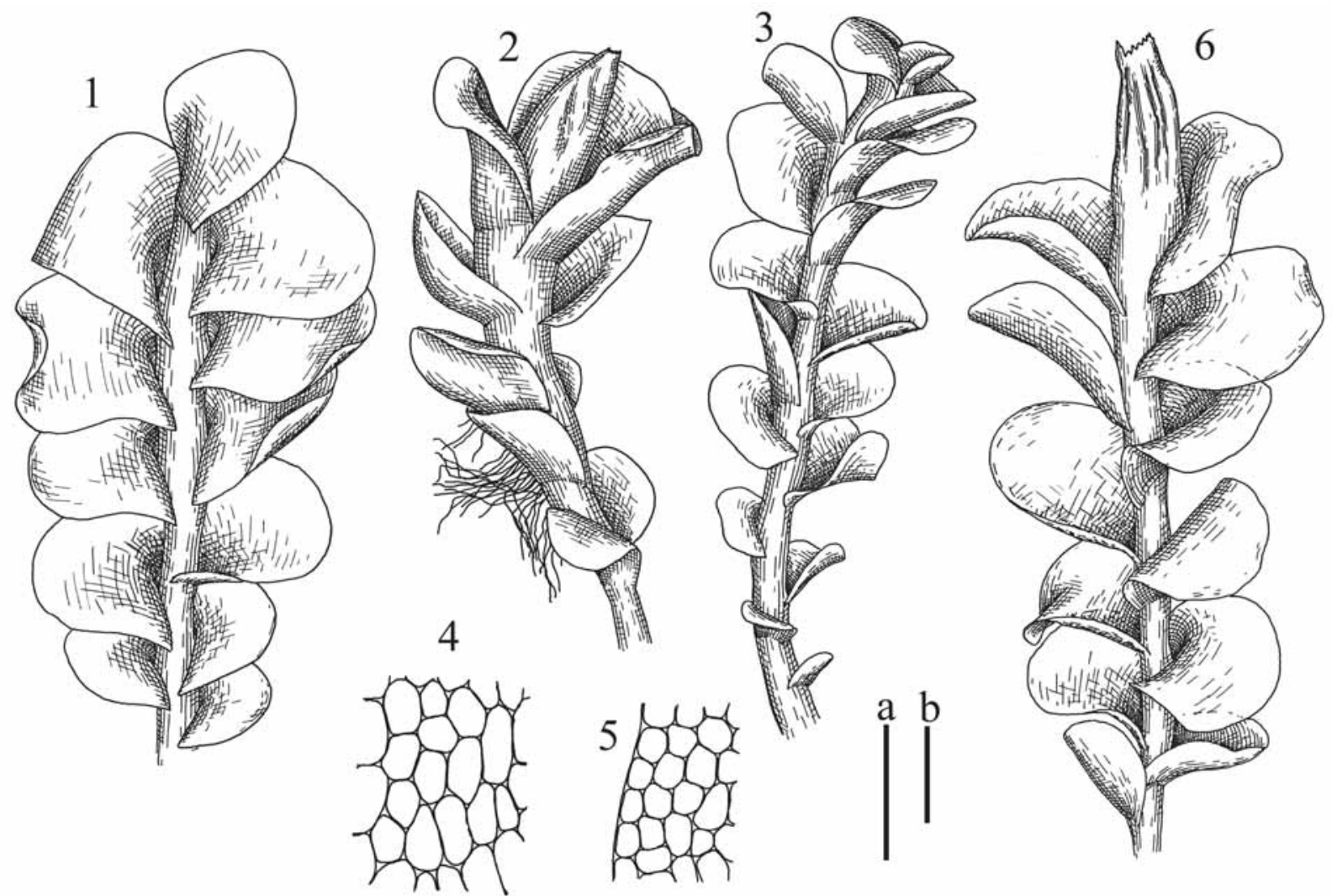

Fig. 10. Jungermannia newellana Steph., holotype (G14302/00112191): 1, 3 - plant habit; 2 - perianthous plant; 4 - midleaf cells; 5 - cells along leaf margin; Jungermannia pallida Steph., holotype (G16629/112139): 6 - perianthous plant. Scales: a - 1 $\mathrm{mm}$, for $1-3,6 ; \mathrm{b}-100 \mu \mathrm{m}$, for 4,5 .

nia mieheana Steph. with J. bauerii Schiffn.) Amak.(= Solenostoma bauerii), with which I agree.

27) Jungermannia mildbraedii Steph., Wiss. Ergebn. Deut. Zentr.-Afr. Exped., Bot. 2: 113. 1910[1911].

Lectotypus (designated by Váňa, 1974b): Congo. Kissenge [Kisenyi]. Lava Spalten des Kraters. 3400 m a.s.1. Mildbraed(?) G14300/00045331.

Accepted name: Solenostoma mildbraedii (Steph.) R.M. Schust., Nova Hedwigia Beiheft 119: 387. 2002.

Description. Plants erect, in dense patches, yellowish brownish to brown near apex, 1.0-1.25 mm wide and 5$10 \mathrm{~mm}$ long. Rhizoids sparse, isolated, obliquely spreading or decurrent down the stem, but not forming fascicle, colorless to brownish. Stem $200-250 \mu \mathrm{m}$ in diameter, not branched, even as subfloral innovations. Leaves clearly dorsally secund, concave to concave-canaliculate (in sterile branches), transversely elliptic, distant, 500$800 \times 750-1250 \mu \mathrm{m}$, dorsally decurrent for $1 / 2-2 / 2 /$ of stem width, subtransversely inserted, obliquely to erect spreading. Midleaf cells oblong, 27.5-43.0×25.0-31.5 $\mu \mathrm{m}$, thin-walled, trigones moderate in size, triangle to convex, cuticle smooth; cells along margin 12.5-18.5 $\mu \mathrm{m}$, thin- to slightly thick-walled, walls brownish, trigones moderate, concave to convex, rarely confluent in tangential wall. Paroicous. Androecia intercalary, below perianth, with 1-2 pairs of bracts that not differed in shape from sterile leaves. Perianth clavate, 3-plicate in upper
$1 / 4-1 / 3$ of the length, ca. $2.25 \times 1.0 \mathrm{~mm}$, suddenly contracted to not beaked mouth, more deeply colored in upper 1/4. (Fig. 9: 3-5). 1917.

28) Jungermannia mosenii Steph., Sp. Hepat. 6: 89.

Holotypus: Brasilia. Prov. Minas Geraes, Caldas. 1.VI.1974. H. Mosen G14482/00112142.

Accepted name: Plectocolea decolor (Schiffn.) Bakalin comb. nov. Basionym Jungermannia decolor Schiffn., Die Forschungsreise S.M.S. Gazell , IV. Teil. Botanik 10. 1889[1890].

Description. Plants olive green to greenish yellowish, erect in dense patches, $1.7-2.8 \mathrm{~mm}$ wide and 8-12 $\mathrm{mm}$ long. Rhizoids numerous, colorless to brown, originated near leaf ventral base (also from perigynium), decurrent down along the stem and forming more or less clear fascicle. Stem $280-380 \mu \mathrm{m}$ in diameter, not branched (even as subfloral innovations). Leaves obliquely to erect spreading, sometimes loosely sheathing the stem near base, concave to concave-canaliculate, 900 $1000 \times 1100-1500 \mathrm{~mm}$, widely obliquely ovate, sometimes slightly undulate at margin, ventrally arcuately inserted, dorsally shortly or up to $1 / 2$ of stem width decurrent. Midleaf cells subisodiametric, 33.5-39.0×27.5-39.0 $\mu \mathrm{m}$, thin-walled, trigones moderate in size, concave to slightly convex, cuticle smooth; cells along leaf margin 15.0 $27.5 \mu \mathrm{m}$, more or less thin-walled, with slightly thick- 
ened external wall, trigones moderate, concave. Dioicous? Perianth 4-5-plicate, conical, gradually narrowed to the mouth, exerted for $1 / 3-1 / 2$ of its length (sometimes more); perianth cells similar to leaf cells; perigynium rhizogenous, ca. $1 / 2-2 / 3$ of perianth length; female branches similar to leaves, but wider and sheathing the perianth at 2/3-3/4 of their length and obliquely spreading above. Spores spherical, finely papillose, $13.5-15.0 \mu \mathrm{m}$ in diameter. Elaters bispiral, without homogenous ends. (Fig. 4: 4-6)

Comment. Váňa (1974b) synonymyzed Jungermannia mosenii Steph. with J. decolor Schiffn. (= Solenostoma decolor (Schiffn.) Bakalin). I did not see the type material of $J$. decolor, but based on Váňa (1974a) description, there is a difference in the size of perigynium, and only tentatively I agre with Ván̆a's conclusion; further study is needed. 1917.

29) Jungermannia newellana Steph., Sp. Hep. 6: 89.

Holotypus: Hawaii. 1911. Newell(?) G14302/ 00112191.

Accepted name: Plectocolea newellana (Steph.) Bakalin comb. nov. Basionym: Jungermannia newellana Steph., Sp. Hep. 6: 89. 1917.

Description. Plants ascending among other hepatics (mostly Riccardia), yellowish brownish, sometimes pallid, 1.75-3.5 mm wide and 10-15 $\mathrm{mm}$ long, rather rigid, sometimes dorsiventrally flattened. Stem 200-275 $\mu \mathrm{m}$ in diameter, sometimes slightly flexuous, not branched (even as subfloral innovations). Rhizoids numerous, deep purple to purple brown, originated in ventral side of stem, decurrent in thick, sometimes loose fascicle down the stem, in some plants erect spreading and not forming the fascicle, in lower part commonly obliquely to erect spreading and forming mat, rigid. Leaves obliquely inserted and obliquely spreading, mostly concave-canaliculate, but in dorsal half of the leaf sometimes slightly convex (giving 'plagiochiloid' appearance), dorsally for 1/4-4/4 decurrent, ventrally mostly arcuately inserted, not decurrent, contiguous to subimbricate, sometimes undulate at margin (especially in large leaves), obliquely lingulate, $1100-1750 \times 1000-1400 \mu \mathrm{m}$. Midleaf cells subisodiametric to oblong, $33.5-62.5 \times 23.5-37.5 \mu \mathrm{m}$, trigones moderate in size, concave, cuticle virtually smooth; cells along leaf margin25.0-37.5 $\mu \mathrm{m}$, thin-walled, with slightly thickened external wall, trigones moderate to small, concave, cuticle smooth. Dioicous? Perianth conical, 4-pluriplicate, evidently, but not strongly turbinate at upper third, ca. $2000 \times 900 \mu \mathrm{m}$, exerted for $1 / 2$ or less of its length; perigynium ca. $1 / 2-2 / 3$ of perianth length, with 1 pair of bracts; female bracts similar to leaves, but larger, undulate and shallowly crispate at margin, sheathing perianth in lower half and recurved away of the perianth in upper 1/3-1/2. (Fig. 10: 1-5).

Comment. Jungermania newellana, along with $J$. mauii Aust. (=Plectocolea mauii (Aust.) Mill. Ark. Bot.
Ser. $2(5 / 2): 513$. 1963.) were synonymyzed under $J$. micrantha (Mitt.) Steph. (= Plectocolea micrantha Mitt.) by Váňa (1975b). Recently I studied the type of $J$. micrantha in NY (Bakalin 2013) and found it to be paroicous. Contrary, plants in the type of $J$. newellana seem to be dioicous. Despite careful search I did not find any antheridia or their remnants in leaves below female bracts. Plants in two types also strongly differ in size and colors. I have not studied the type of $P$. mauii and cannot conclude if it is identical with $P$. newellana, $P$. micrantha or represents the third species of its own.

30) Jungermannia obtusiflora Steph., Sp. Hepat. 2: 69. 1901. (= Jungermannia obtusiflora Gottshe, in litt.).

Holotypus: Guadeloupe. l'Herminier G14487/115155. Accepted name: Solenostoma linguifolium (Gottsche) R.M. Schust., Nova Hedwigia Beiheft 119: 381. 2002.

Description. Plants prostrate, dorsiventrally flattened, more or less rigid (leaves even fragile when detaching them), brownish green to brownish, 3.0-3.5 mm wide and 10-15 mm long. Rhizoids brownish to brown, rarely with purplish tint, rigid, originated mostly near ventral leaf base, but not only there, decurrent down the stem, but not forming fascicle. Stem 320-380 $\mu \mathrm{m}$ in diameter, not branched, brown. Leaves contiguous, concave-canaliculate, laterally spreading, rigid, ovate to obliquely ovate, 1500$2000 \times 1250-1500 \mathrm{~mm}$, obliquely inserted, dorsally barely decurrent, ventrally transversely to arcuately inserted, not or barely decurrent. Midleaf cells oblong, 37.5-56.5×31.0 $37.5 \mu \mathrm{m}$, thin-walled, trigones large, convex, cuticle smooth; cells along leaf margin 31.0-37.5 $\mu \mathrm{m}$, thin-walled, external wall strongly thickened, trigones large, convex, cuticle virtually smooth. (Fig. 11: 1-7).

Comment. Váňa (1974a) treats J. obtusiflora as a modification of $J$. linguifolia with ascending stem.

31) Jungermannia pallida Steph., Sp. Hepat. 6: 90. 1917.

Holotypus: Japan. 1907. U. Jishiba (no. 79) G16629/ 112139 .

Accepted name: Plectocolea grossitexta (Steph.) S. Hatt. Bull. Tokyo Sci. Mus. 11: 38. 1944.

Description. Plants pallid, prostrate, whitish to pale brownish, commonly tinged with purple near shoot apices (in exposed places), 1.5-3.0 mm wide and 7-10 $\mathrm{mm}$ long, dorsiventrally flattened, soft. Rhizoids numerous, colorless to grayish, loosely attached plant to the substratum, originated from the stem. Stem $175-300 \mu \mathrm{m}$ in diameter, not branched. Leaves ovate to obliquely ovate, 1050-1500×950-1500 $\mu \mathrm{m}$, lax, contiguous, laterally spreading, undulate at margin, loosely sheathing the stem near base, dorsally decurrent for $1 / 3-3 / 3$ of stem width, ventrally arcuately inserted, not or shortly decurrent. Midleaf cells oblong, 37.5-62.5×18.5-31.5 $\mu \mathrm{m}$, very thinwalled, trigones wanting to very small, triangle, cuticle smooth; cells along leaf margin $25.0-47.5 \mu \mathrm{m}$, thinwalled, with thickened external wall, trigones small, con- 


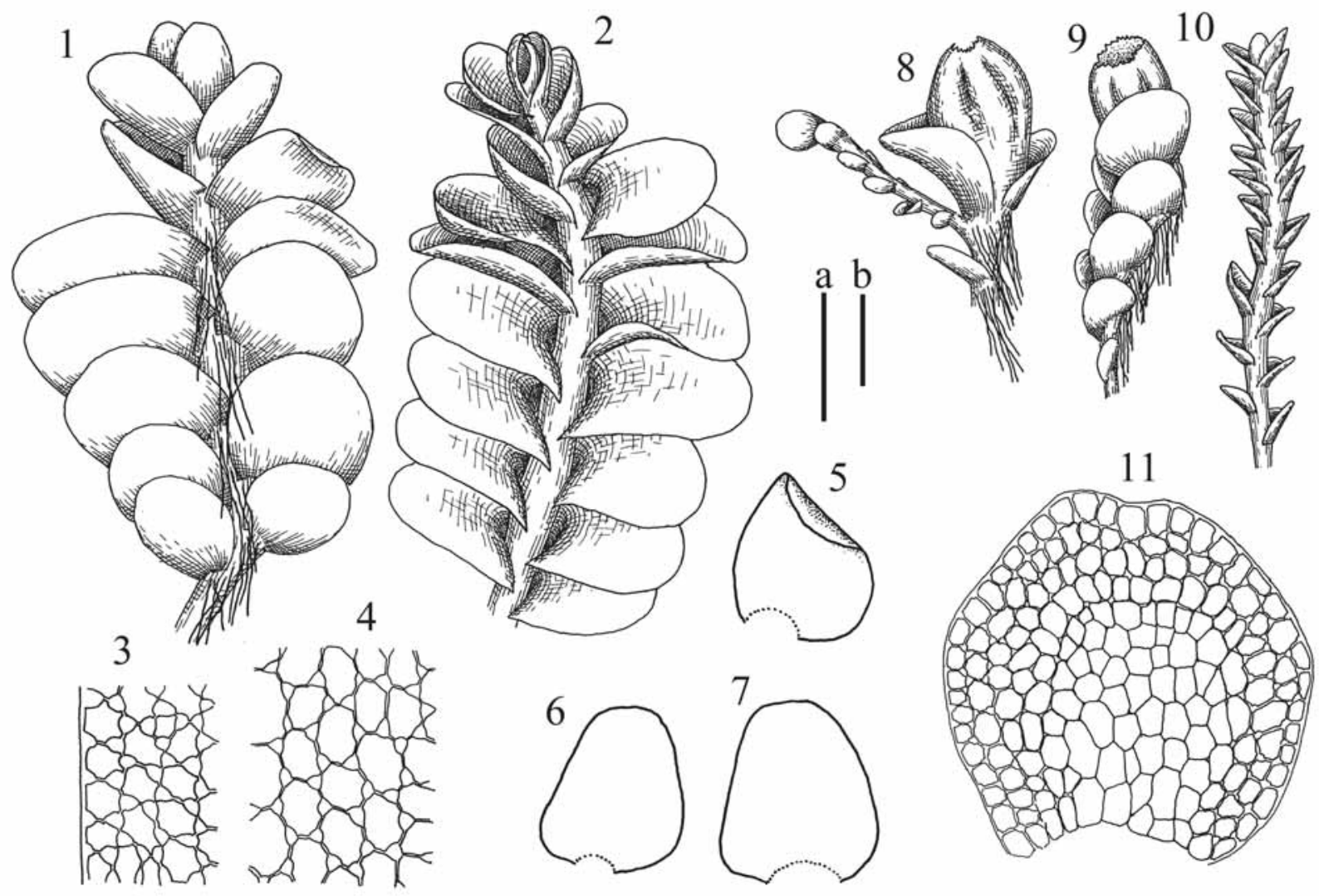

Fig. 11. Jungermannia obtusiflora Steph., holotype (G14487/115155): 1 - plant habit, ventral view; 2 - plant habit; 3 - cells along leaf margin; 4 - midleaf cells; 5-7 - leaves; Jungermannia papulosa Steph., holotype (G14471/00112138): 8, 9-perianthous plants; 10 - plant habit; 11 - leaf. Scales: a $-1 \mathrm{~mm}$, for $1,2,5-7$; b - $100 \mu \mathrm{m}$, for 3, 4, 11; a - $590 \mu \mathrm{m}$, for 8-10.

cave, cuticle smooth. Dioicous? Perianth pluriplicate, but commonly with 3 main plicae, long-conical, 1750-550 $\mu \mathrm{m}$, gradually narrowed to the mouth, exerted for $2 / 3$ of the length; perigynium ca. $1 / 3-1 / 2$ of perianth length; female bracts similar to leaves, but larger and sometimes crispate along margin. (Fig. 10: 6).

Comment. This name was synonymyzed with Jungermannia thermarum Steph. by Amakawa (1960). Later Ván̆a (1974d) placed Jungermannia pallida (as syn. nov.) into synonym of Jungermannia vulcanicola (Schiffn.) Steph (= Plectocolea vulcanicola (Schiffn.) Bakalin). However one year later Váňa (1975c) transferred J. pallida into synonym of $J$. torticalyx Steph. (= Plectocolea torticalyx (Steph.) S. Hatt.), as the latter was found by him as a species with great variability. However, based on a combination of prostrate growth form, pallid color, colorless rhizoids, leaves commonly longer than wide, perianth exerted for $2 / 3$ of its length, and not turbinate mouth I suggest $J$. pallida is synonymous with Plectocolea grossitexta (Steph.) S. Hatt., with the latter being priority name.

32) Jungermannia papulosa Steph., Sp. Hepat. 2: 73. 1901.

Holotypus: Brasilia. Minas Gerais. Lindman (No. 23 p.p.) G14471/00112138.

Accepted name: Solenostoma papulosum (Steph.) Bakalin, Arctoa 23: 95. 2014.
Description. Plants from "flagelliform" base with scalelike leaves to normally leaved shoots, pale brownish to yellowish brown, $0.2-0.4$ (perianthous up to 0.7 ) $\mathrm{mm}$ wide and 3-5 mm long. Rhizoids colorless to grayish, erect spreading (not united into spreading fascicles). Stem 100 $125 \mu \mathrm{m}$ in diameter, not branched, with exception of lateral subfloral innovations. Leaves subtransversely inserted, not decurrent in the both sides, although leaves near perianth (just below female bracts) ventrally arcuately inserted, 225-325 $\times 175-325 \mu \mathrm{m}$, distant, concave, ovate to suborbicular. Midleaf cells subisodiametric to shortly elongate, $23.5-31.5 \times 18.5-27.5 \mu \mathrm{m}$, thin-walled, with moderate in size to small, mostly concave trigones, cuticle virtually smooth; cells along leaf margin 15.0-27.0 $\mu \mathrm{m}$, more or less thin-walled, trigones small to moderate in size, concave to convex, external wall thickened. Dioicous? Perianth 4-plicate in upper $2 / 3$, gradually narrowed to not beaked mouth; perigynium virtually absent; female bracts similar to leaves, but larger. (Fig. 11: 8-11).

Comment. Jungermannia papulosa Steph. (=Solenostoma papulosum (Steph.) Bakalin) was synonymized with Jungermannia amoena Lindenb. \& Gott. (Solenostoma amoenum (Lindenb. \& Gott.) R.M. Schust. ex Váňa, Hentschel \& J. Heinrichs) by Váňa (1974a). On the contrary, I consider Solenostoma papulosum as a 'good' species. For further explanations see comment under Jungermannia brasiliensis Steph. 
33) Jungermannia potamophila Müll.Arg. ex Moug., Nestl. \& Schimp., Stirpes Cryptogamae Vogeso-Rhenanae 15: 1418.1860.

Isotypus: Switzerland. 1856. J. Muller. (No. 167) G14571/00115172.

Accepted name: Jungermannia atrovirens Dumort., Syll. Jungerm. Europ. 51. 1831.

Comment. The name was synonymyzed with Jungermannia atrovirens Dumort. by Váňa (1973) (mod. viridis-leptoderma-laxifolia). I agree with this conclusion. Plants slightly differ from most common phenotypes of $J$. atrovirens in wider shoots and not so strongly laterally spreading leaves. (Fig. 12: 1, 2)

34) Jungermannia purpurata Mitt., J. Proc. Linn. Soc., Bot. 5: 91. 1860[1861].

Isotypus(?). “Simla. Dripping rocks. Griffith” G8180/ 115095.

Accepted name: Solenostoma purpuratum (Mitt.) Steph., Sp. Hepat. 2: 51. 1901.

Description. Plants seem to be ascending to erect, brownish-greenish to brownish-green, $1.75-2.5 \mathrm{~mm}$ wide and $10-15 \mathrm{~mm}$ long, without purple pigmentation. Stem 200-250 $\mu \mathrm{m}$ in diameter, not branched, straight, greenish brownish. Rhizoids numerous, originated in ventral side of stem, decurrent down the stem in wide (sometimes wider than stem) distinct fascicle, colorless to grayish. Leaves contiguous, obliquely to erect spreading, concave to concave-canaliculate (smaller ones), transversely to subtransversely inserted, shortly (ca. 1/4-1/2 of stem width) decurrent dorsally and arcuately inserted and decurrent for $1 / 2-2 / 2$ of stem width ventrally, commonly undulate at margin, rarely (the biggest ones) crispate, widely obliquely ovate to widely obliquely triangular, 700-1400×750-1900 $\mu \mathrm{m}$. Midleaf cells subisodiametric to shortly oblong, $25.0-37.5 \times 18.7-25.0 \mu \mathrm{m}$, thin-walled, trigones moderate in size, cuticle virtually smooth; cells along leaf margin 15.0-19.0 $\mu \mathrm{m}$, thin-walled, trigones moderate in size, convex, external wall thickened. Dioicous. Androecia intercalary (although sometimes branch become depauperate and die out after androecia), with 5-6 pairs of bracts, smaller than leaves, inflated in lower half and erect spreading in upper half. Perianth widely clavate, ca. $2000 \times 1400 \mu \mathrm{m}$, not or very loosely 4-plicate in upper $1 / 4$, suddenly contracted to obscurely beaked mouth, composed by subisodiametric cells, bistratose in lower $2 / 3$; perigynium virtually absent or very low; female bracts in one pair, similar to leaves, but larger, concave. Spores finely papillose, $15.0-16.5 \mu \mathrm{m}$ in diameter. Elaters bispiral, ca. $115 \times 10 \mu \mathrm{m}$, with homogenous ends ca. 19-20 $\mu \mathrm{m}$ long. (Fig. 12: 10, 11).

Comments. a) Other isotypes, G00115096 and G00115094, are identical with the above described, but dhe to a possibility of their non-identity, description is given for one specimen.

b) W. Mitten (1861) provides locality data as "In montis khasianae Bengaliae orient. reg. trop. alt. 2000-
4000 ped. Griffith" (No. 1327), but on the label in G only "Simla. Dripping rocks. Griffith" is mentioned (G8180/115095). The same geography is mentioned in the lectotype label in NY (NY00967458!), plants in the lectotype from NY are similar in all ways to the present specimen, although shoots are slightly narrower.

35) Jungermannia pyriflora Steph., Sp. Hepat. 6: 90. 1917.

Holotypus: Japan. Shinano, Mt. Natruzawo. 28.VII.1908. U. Jishiba (No. 205) G530/00067158.

Accepted name: Solenostoma pyriflorum Steph., Sp. Hepat. 6: 83. 1917.

Description. Plants erect, in dense patches, more or less small, 1.25-1.5 mm wide and 3-5 mm long, yellowish brownish. Rhizoids colorless, sparse to numerous, erect to obliquely spreading in unclear fascicles, rarely forming unclear fascicle decurrent down the stem. Stem 250-300 $\mu \mathrm{m}$ in diameter, not branched (even as subfloral innovations). Leaves subtransversely inserted, dorsally barely decurrent, or decurrent up to $1 / 4$ of stem width, ventrally transversely to arcuately inserted, not decurrent, 500 $800 \times 700-1175 \mu \mathrm{m}$, suborbicular to transversely elliptic, contiguous to subimbricate. Midleaf cells mostly isodiametric to shortly oblong, $25.0-37.5 \times 25.0-29.0 \mu \mathrm{m}$, thinwalled, trigones moderate in size, convex, cuticle smooth; leaf margin cells $16.0-22.5 \mu \mathrm{m}$, thin-walled, trigones convex to concave, moderate to large in size, external wall thickened, cuticle smooth. Dioicous. Perianth 3-4-plicate in upper $1 / 3-1 / 2$ of its length, 2-3-stratose in lower $2 / 3$, exerted for 2/3-3/4 of its length, subclavate, ca. $1100 \times 600$ $\mu \mathrm{m}$. Androecia intercalary, with (2)3-4 pairs of bracts, different generations divided by 1-2 pairs of sterile leaves, male bracts strongly inflated in lower half and erect spreading near bract margin. (Fig. 13: 1, 2).

Comment. Stephani (1917) used epithet "pyriflorum" twice within Jungermannia s.1. He described Solenostoma pyriflorum Steph. on page 83 and 7 pages below, on page 90, described also Jungermannia pyriflora Steph. Both names seem to be synonymous to each other, or, at least, very closely morphologically related. Small differences may be found in leaf cell size. I suggest to synonymize two names only provisionally, because further studies in this group in Japan and adjacent areas are needed.

Solenostoma pyriflorum Steph., Sp. Hepat. 6: 83. 1917. - Jungermannia pyriflora Steph. Sp. Hepat. 6: 90. 1917. syn. nov. prov.

36) Jungermannia renauldii Steph., Bull. Soc. Bot. Belgique 30: 201. 1892.

Holotypus: Reunion (Bourbon). Rodriguez (No. 276) G14303/00045333.

Accepted name: Plectocolea renauldii (Steph.) Bakalin comb. nov. Basionym: Jungermannia renauldii Steph., Bull. Soc. Bot. Belgique 30: 201. 1892.

Description. Plants prostrate to indistinctly ascending, greenish-brownish to brownish-yellowish, 1.5-2.0 

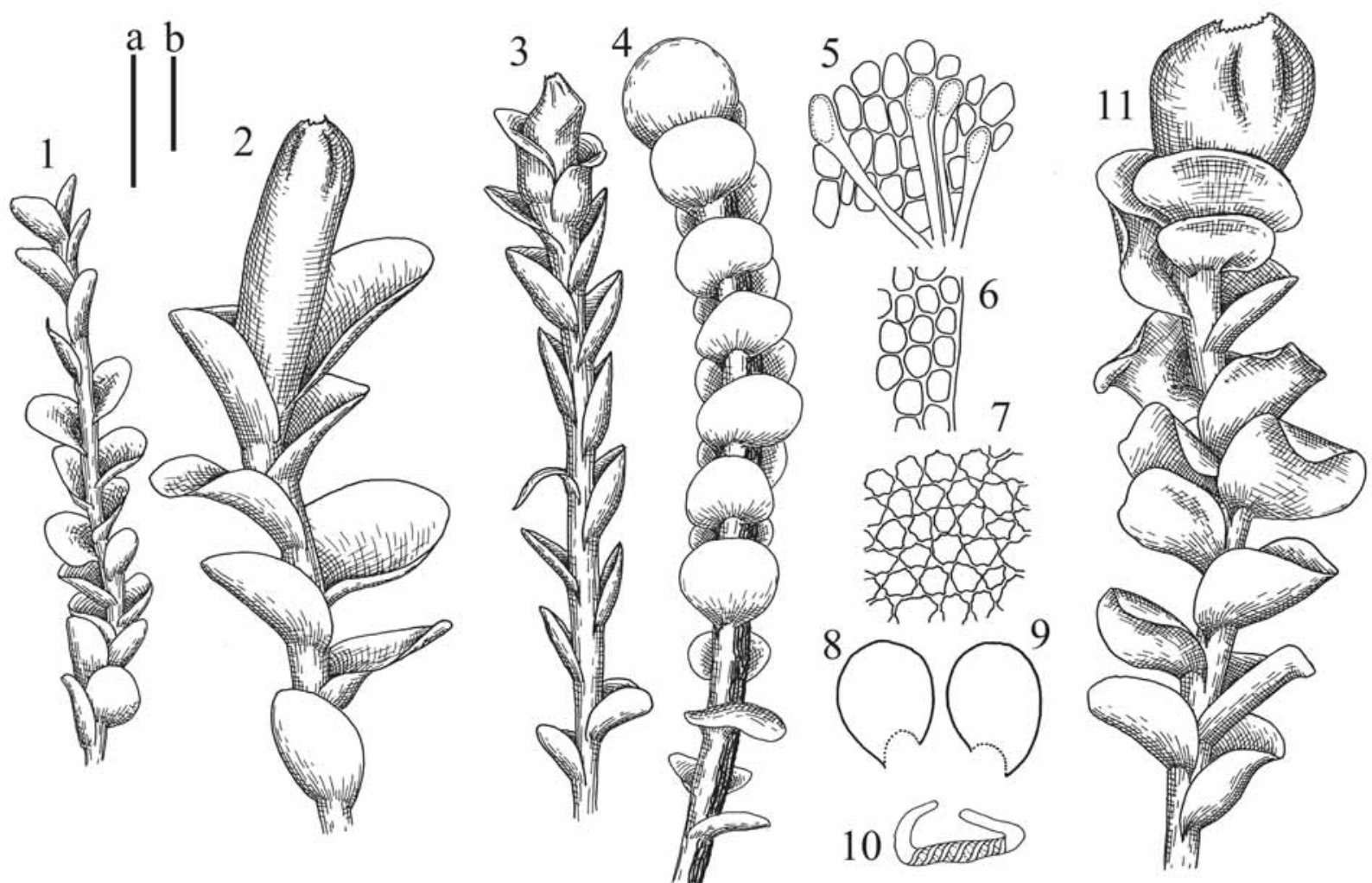

Fig. 12. Jungermannia potamophila Müll. Arg. ex Moug., Nestl. \& Schimp., isotype (G14571/00115172): 1 - plant habit; 2 perianthous plant; Nardia prostrata Steph., holotype (G516/00115364): 3 - perianthous plant; 4 - plant habit, lateral view; 5 rhizogenous cells in the leaf; 6 - cells along leaf margin; 7 - midleaf cells, 8, 9 - leaves; Jungermannia purpurata Mitt., isotype (G8180/115095 ): 10 - elater; 11 - perianthous plant. Scales: $\mathrm{a}-1 \mathrm{~mm}$, for $1-4,8,9,11 ; \mathrm{b}-100 \mu \mathrm{m}$, for $5-7$; $\mathrm{b}-50 \mu \mathrm{m}$, for 10 .

$\mathrm{mm}$ wide and 5-10 $\mathrm{mm}$ long. Rhizoids colorless to grayish and brownish, erect to obliquely spreading, in indistinct fascicles, or decurrent down the stem, but not forming fascicles, originated mostly near ventral leaf base. Stem 175 $300 \mu \mathrm{m}$ in diameter, not branched (with the exception of ventral subfloral innovations). Leaves obliquely inserted, concave-canaliculate, distant to contiguous, dorsally decurrent for (1/2)1-2 stem width, ventrally arcuately inserted, not or barely decurrent, obliquely ovate, more or less rigid, $870-1000 \times 750-1050 \mu \mathrm{m}$. Midleaf cells subisodiametric to oblong, $25.0-37.5 \times 22.5-30.0 \mu \mathrm{m}$, thin-walled, trigones moderate in size, convex, cuticle distinctly papillose; cells along leaf margin 25.0-37.5 $\mu \mathrm{m}$, subequally thickened, trigones moderate in size, concave, cuticle papillose-verrucose (rarely with large verrucae along margin). Dioicous. Perianth irregularly conical, 5-pluriplicate, gradually narrowed to the mouth, hidden within bracts or exerted for $1 / 3-1 / 2$ of its length, perianth cells moderately differ from leaf cells; perigynium ca. $1 / 2-2 / 3$ of perianth length, with 1(2) pairs of bracts; female bracts shallowly retuse at the apex, similar to leaves, but wider, long decurrent dorsally. (Fig. 13: 3-10).

37) Jungermannia riparia Tayl. var. major Gottsche et Rabenh., Hepaticae Europeae, No. 276

Lectotypus (designated by Váňa 1973): Germany. Bruggen. U. Geheeb G00114367.
Accepted name: Jungermannia atrovirens Dumort., Syll. Jungerm. Europ. 51. 1831.

Comment. Váňa (1973) synonymized it with $J$. atrovirens Dumort. s. str. mod. viridis-leptoderma-laxifolia, which I fully accept.

38) Jungermannia rupicola Amakawa, J. Hattori Bot. Lab. 22: 23. 1960.

Isotypus: Japan. Kyushu, Miyazaki Pref. 2.IV.1953. T. Amakawa (Hepaticae Japonicae Exsiccatae. Ser. 12. No. 572) G00115163.

Accepted name: Plectocolea rupicola (Amakawa) Bakalin, Arctoa 18: 26. 2009.

Description. Plants ascending to erect, in rather loose patches, brownish-purplish to brown-purple in upper parts of shoots, more or less rigid, 2.5-3.5 mm wide and 10-18 $\mathrm{mm}$ long. Stem not branched, $225-275 \mu \mathrm{m}$ in diameter, brownish. Rhizoids purple to colorless in the most cases forming clear fascicle decurrent down the stem, rarely (near branch base) erect spreading and separated (not in the fascicle). Leaves rigid, canaliculate to concave-canaliculate, obliquely (ca. 45-50? with axis) inserted, dorsally become very obliquely inserted, decurrent for $1 / 4-1 / 3$ of stem width, ventrally arcuately inserted, not or barely decurrent, sometimes (in area of shoot adjacent to the perianth) undulate at margin, obliquely ovate, $1600-1750 \times 1600-1750 \mu \mathrm{m}$ (1:1). Midleaf cells subisodiametric to oblong, (18.5)25.0 

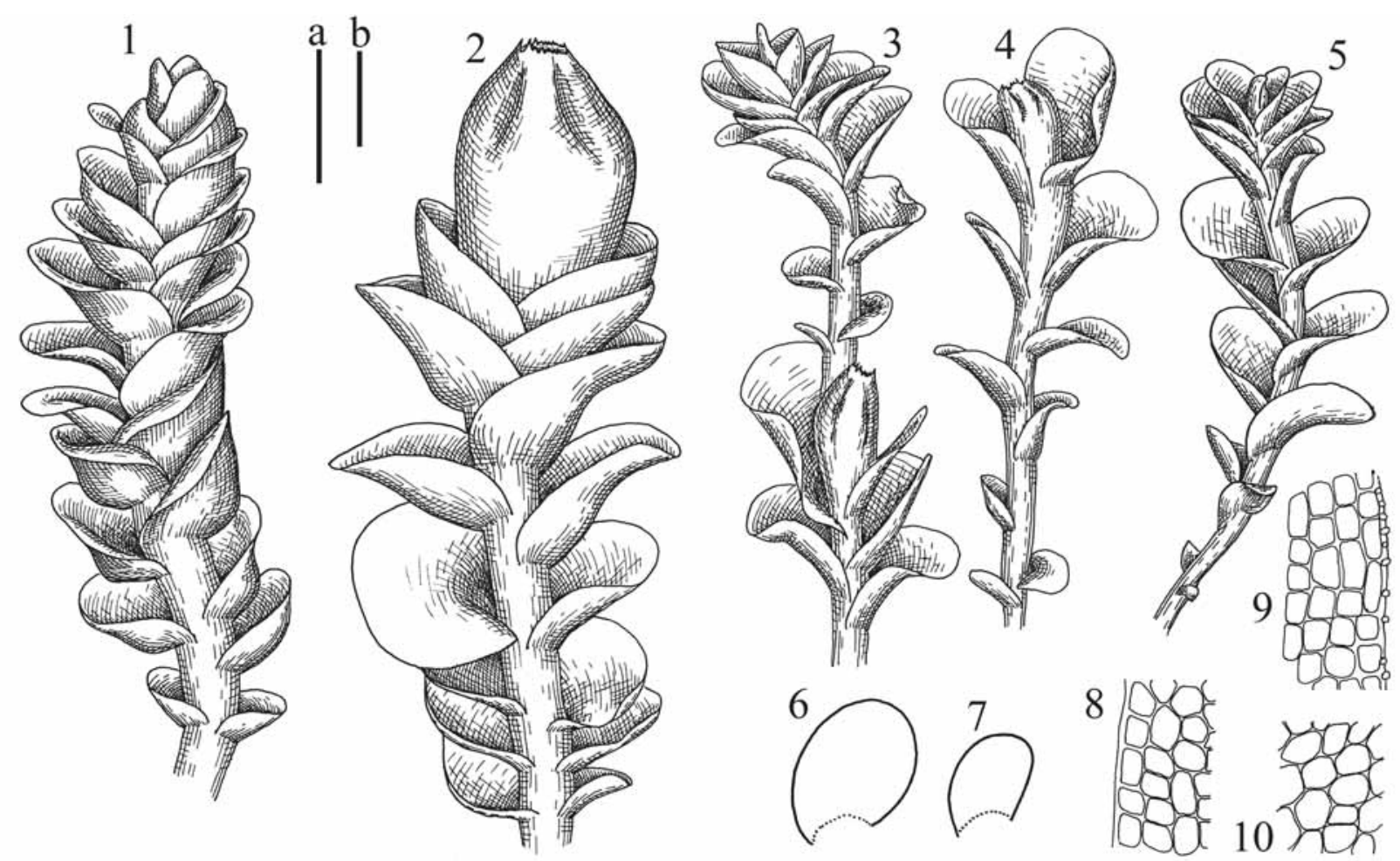

Fig. 13. Jungermannia pyriflora Steph., holotype (G530/00067158): 1 - male plant; 2 - perianthous plant; Jungermannia renauldii Steph., holotype (G14303/00045333): 3, 4 - perianthous plants; 5 - plant habit; 6, 7 - leaves; 8, 9 - cells along leaf margin; 10 - midleaf cells;. Scales: $\mathrm{a}-1 \mathrm{~mm}$, for 3-7; b-100 $\mu \mathrm{m}$, for $8-10$; a-500 $\mu \mathrm{m}$, for 1, 2 .

$37.5 \times 22.5-31.5 \mu \mathrm{m}$, thin-walled, trigones moderate, convex, cuticle smooth; cells along leaf margin $18.5-23.0 \mu \mathrm{m}$, thin-walled, with moderate to large in size, convex trigones, external wall thickened, cuticle smooth; cuticle in basal part of the leaf striolate. Dioicous. Perianth pluriplicate (mostly with 5-6 main plicae), purple in color, loosely turbinate at the mouth, exerted for $1 / 2-2 / 5$ of its length, conical, ca. $1.7 \times 0.9 \mathrm{~mm}$; perigynium ca. $1 / 3$ of perianth length or smaller; female bracts closely sheathing the perianth in lower $1 / 2-2 / 3$ of their length and erect spreading above. (Fig. 14: 1-4).

Comment. Váňa (1975c) synonymized Jungermannia rupicola (= Plectocolea rupicola (Amakawa) Bakalin) with $J$. rosulans (=Plectocolea rosulans (Steph.) S. Hatt.), however later Ván̆a \& Long (2009) treated both species separately, as Solenostoma rupicola (Amakawa) Váňa et D.G. Long and S. rosulans (Steph.) Váňa et D.G. Long respectively without discussion on their status. In my opinion two taxa are different due to the following reasons: P. rupicola is characterized by common presence of purple to purplish coloration, erect growth form and subtransversely inserted and oriented leaves, whereas $P$. rosulans nearly totally lacks purplish or reddish pigmentation, and has obliquely inserted and very obliquely oriented leaves.

39) Jungermannia rufiflora Col., Trans. Proc. New Zealand Institute 18: 237. 1886.

Isotypus: New Zealand. Waipawa Co. (No. 1361) G14441/00115161.
Accepted name: Solenostoma rufiflorum (Colenso) J. Engel, Novon 17: 312. 2007.

Description. Plants ascending to erect, in dense patches, brownish to yellowish-brownish, marked with red or purple at the tips (especially in upper half of perianth), $0.5-1.0 \mathrm{~mm}$ wide and 3-5 mm long. Rhizoids sparse to common, mostly erect spreading, sometimes in unclear fascicles, colorless to grayish. Stem $100-170 \mu \mathrm{m}$ in diameter, not branched, brownish. Leaves concave, contiguous to imbricate, subtransversely inserted, dorsally shortly decurrent, ventrally arcuately inserted, not or barely or up to $1 / 2$ of stem width decurrent, 650 $1000 \times 750-1050 \mu \mathrm{m}$, suborbicular to ovate-orbicular. Midleaf cells isodiametric to shortly oblong, 27.5$37.5 \times 22.0-31.5 \mu \mathrm{m}$, thin-walled, with moderate in size, mostly convex trigones, cuticle smooth; cells along leaf margin 21.0-27.5 $\mu \mathrm{m}$, thin-walled, with large, convex trigones, external wall noticeable thickened, cuticle smooth. Paroicous? (I did not see androecia, but 2-3 pairs of leaves below female bracts characteristically inflated near their bases) Perianth terminal, (4)5-plicate in upper $2 / 3$, gradually narrowed to the not beaked mouth, exerted for $2 / 3$ of its length; female bracts concave, sheathing the perianth in lower part. (Fig. 14: 5, 6).

Comment. The taxon was synonymyzed by Váňa (1975a) with Jungermannia inundata Hook. f. et Tayl. Engel \& Glenny (2008) did not confirm this and provided arguments in favor of treating these taxa separately (on species level) and I fully agree with them. 

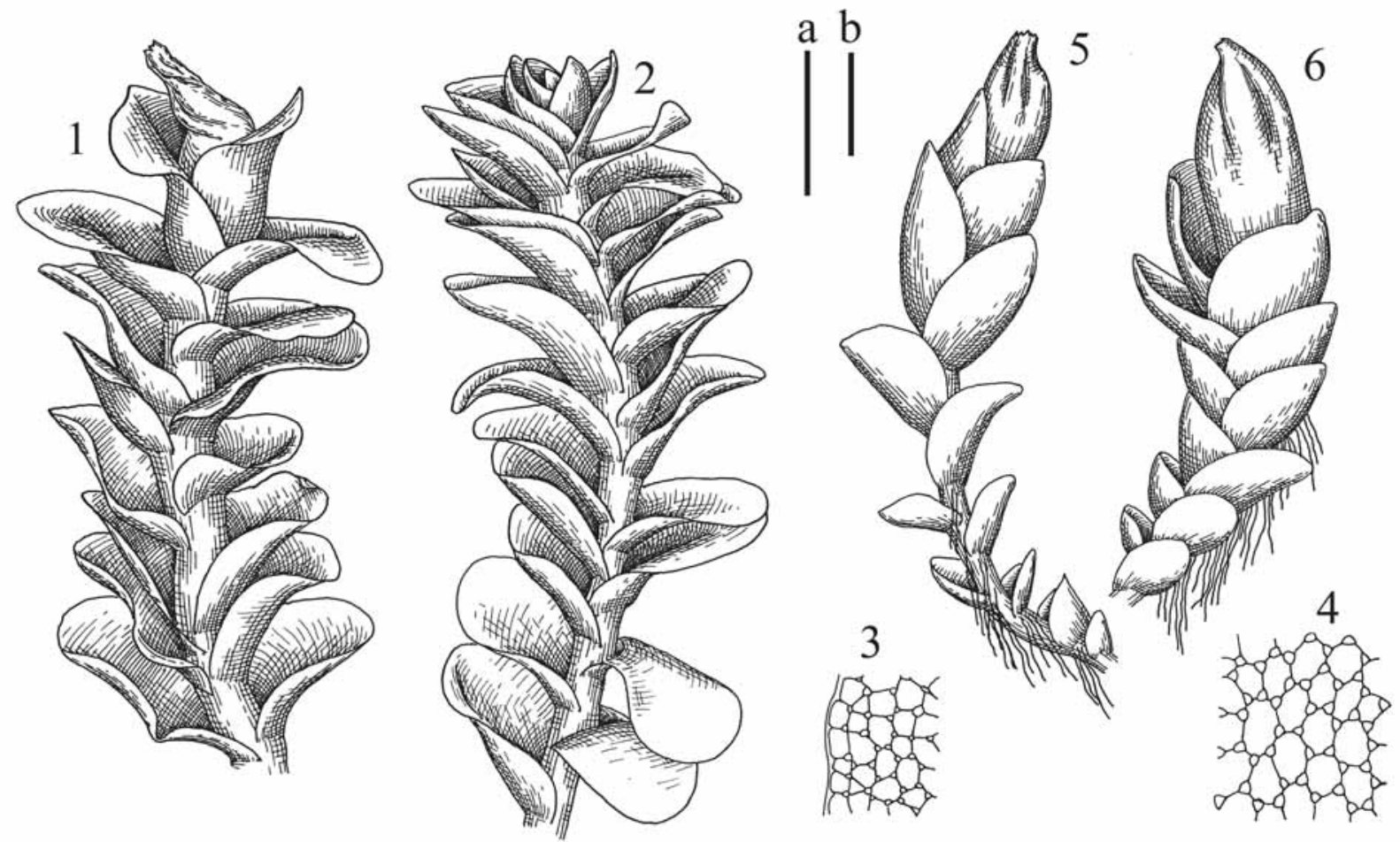

Fig. 14. Jungermannia rupicola Amakawa, isotype (G00115163): 1 - perianthous plant; 2 - plant habit; 3 - cells along leaf margin; 4 - midleaf cells; Jungermannia rufiflora Col., isotype (G14441/00115161): 5, 6 - perianthous plants. Scales: a - $1 \mathrm{~mm}$, for $1,2,5,6 ; b-100 \mu \mathrm{m}$, for 3,4 .

40) Jungermannia schauliana Steph., Sp. Hepat. 6: 90. 1917. (= Aplozia schauliana Schiffn. in litt.).

Lectotypus (selected by Amakawa, 1967): India. Sikkim. $2200 \mathrm{~m}$ a.s.1. 1.I.1900 Decoly et Schaul G674/ 00067151.

Accepted name: Solenostoma schaulianum (Steph.) Váňa \& D.G. Long, Nova Hedwigia 89: 508. 2009.

Description. Plants prostrate to obscurely ascending, greenish to greenish-brownish, loosely attached by rhizoids to the substratum, $3.0-3.5 \mathrm{~mm}$ wide and $7-12 \mathrm{~mm}$ long, forming loose patches, plants dorsiventrally flattened. Stem 200-275 $\mu \mathrm{m}$ in diameter, straight to obviously flexuous, not branched, brownish. Rhizoids common, rigid, brownish, originated mostly near ventral leaf base (but not only there), obliquely spreading, separated or united into unclear fascicles, or sometimes obliquely spreading upward to the shoot apex. Leaves contiguous (partly overlapping one to another), very obliquely inserted and oriented, dorsally decurrent for $1 / 5-1 / 3$ of stem width, ventrally subtransversely to arcuately inserted, not or barely decurrent, slightly concave to slightly canaliculate-concave, ovate to elliptic, 750-1600×700-1500 $\mu \mathrm{m}$. Midleaf cells subisodiametric to shortly oblong, 36.0$56.5 \times 26.0-44.0 \mu \mathrm{m}$, thin-walled, trigones moderate in size, convex, cuticle virtually smooth; cells along leaf margin 25.0-36.2 $\mu \mathrm{m}$, thin-walled, with thickened external wall, trigones moderate to large, convex, cuticle smooth. Dioicous? Perianth shortly fusiform to clavate, ca. $1400 \times 750 \mu \mathrm{m}, 3$-plicate (plicae not acute) in upper half, gradually narrowed in upper $2 / 5$ to not beaked mouth, composed by subisodiametric cells, bistratose in lower $1 / 3$. Spores finely papillose, $12.5-14.0 \mu \mathrm{m}$ in diameter. Elaters bispiral, ca. $113 \times 8 \mu \mathrm{m}$, with homogenous ends 19-25 $\mu \mathrm{m}$. (Fig. 15: 1-8).

Comment. Three specimens are present in $\mathrm{G}$, one of them containing more material was selected as lectotype by Amakawa (1967). Other syntypes are the following: 1) G675/00067153, only a few plants are present, some of them more deeply brownish colored along leaf margin near shoot apices; 2) G23992/00067152 contains mostly Scapania, Cephalozia, Solenostoma appressifolium and only a few plants of S. schaulianum.

41) Jungermannia sexplicata Steph., Sp. Hepat. 6: 91. 1917.

Holotypus: Hawaii. 1500 ft. Newell (No. 165). G14305/00067150.

Accepted name: Plectocolea sexplicata (Steph.) Bakalin comb. nov. (Plectocolea sexplicata (Steph.) Mill. in litt.) Basionym: Jungermannia sexplicata Steph., Sp. Hepat. 6: 91. 1917.

Description. Plants creeping to loosely ascending, in loose patches, greenish-brownish to brownish-yellowish, loosely attached by rhizoids to the substratum, 1.0 1.25(1.4) mm wide, 4-8 mm long. Stem 150-200 $\mu \mathrm{m}$ in diameter, slightly flexuous, not branched, with the exception of ventral subfloral innovations (becoming into normal branch and after 3-4 mm produce perianth again). Rhizoids numerous, originated from ventral side of stem, 

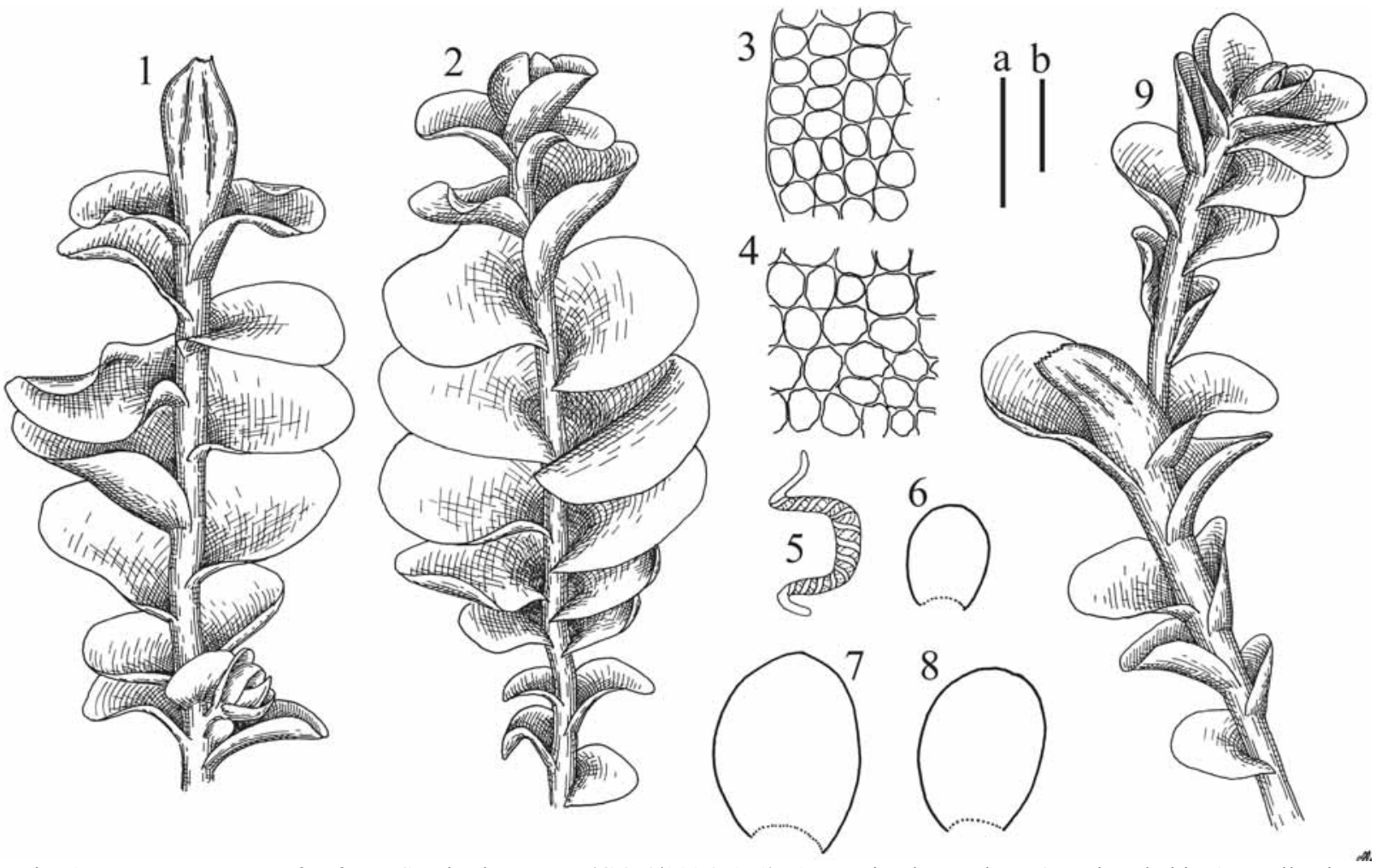

Fig. 15. Jungermannia schauliana Steph., lectotype (G674/00067151): 1 - perianthous plant; 2 - plant habit; 3 - cells along leaf margin; 4 - midleaf cells, 5 - elater; 6-8 - leaves; Jungermannia sexplicata Steph., holotype (G14305/00067150): 9 perianthous plant. Scales: $\mathrm{a}-1 \mathrm{~mm}$, for $1,2,6-8 ; \mathrm{b}-100 \mu \mathrm{m}$, for 3,4 ; $\mathrm{a}-590 \mu \mathrm{m}$, for 9 ; $\mathrm{b}-50 \mu \mathrm{m}$, for 5 .

colorless to brownish, obliquely spreading or decurrent down the stem, but not forming distinct fascicle. Leaves obliquely to very obliquely inserted, dorsally not or barely decurrent, ventrally subtransversely to arcuately inserted, not or barely decurrent, slightly concave to loosely concave-canaliculate, obliquely to (rarely) erect spreading, obliquely ovate to obliquely lingulate, rarely emarginated at apex, 500-800 $\times 475-800 \mu \mathrm{m}$. Midleaf cells subisodiametric to shortly oblong, $37.5-56.5 \times 31.0-50.0$ $\mu \mathrm{m}$, thin-walled, trigones moderate, slightly concave or slightly convex, cuticle smooth; cells along leaf margin $22.5-50.0 \mu \mathrm{m}$, thin-walled, external wall thickened, trigones moderate to large, rarely confluent in tangential wall; cuticle smooth. Gemmae rarely occur, unicellular, spherical, $20-30 \mu \mathrm{m}$ in diameter. Dioicous? Perianth conical to (rarely, probably with unfertilized archegonia only) fusiform, 3-plicate (sometimes with many additional plicae), ca. $900 \times 450 \mu \mathrm{m}$; perigynium vestigial or up to $1 /$ $4(1 / 3)$ of perianth length; female bracts similar to leaves, loosely sheathing perianth in lower $1 / 3-1 / 2$ and obliquely spreading above. (Fig. 15: 9).

Comment. Jungermannia sexplicata Steph. $(=$ Plectocolea sexplicata (Steph.) Bakalin) was synonymyzed with $J$. micrantha (Mitt.) Steph. (= Plectocolea micrantha Mitt.) by Váňa (1975b) as a probable shaded form characterized by green color, etiolate small plants with distant leaves and gemmae(!) production. I cannot agree with this statement. By appearance, even sterile plants easily differ from both Plectocolea micrantha Mitten and
Plectocolea mauii (Aust.) Mill. by creeping growth, pale color, low perigynium and absence of purplish coloration in the rhizoids. That appearance cannot be recognized as "eine Schattenform" (Váňa, 1975b: 361) due to well developed trigones in leaf lamina cells and thickened cell walls along leaf margin. Also taking into account the ability of Plectocolea sexplicata to produce gemmae (supposedly not present in well developed shoots of the same species, Váña, 1975b), I think the position of P. sexplicata should be in the group Plectocolea trunca$t a-P$. rubripunctata, but not in the group P. micranthaP. mauii characterized by purple to purplish rigid rhizoids, bright color and absence of gemmae.

42) Jungermannia sikkimensis Steph., Sp. Hepat. 6: 92. 1917. (=Nardia sikkimensis Schiffn. in litt., 1902).

Neotypus nov*: India. West Bengal, Kurseong. 610 m alt. 22.XI.1899 Decoly et Schaul G548/00115079.

* Stephani (1917) cites "Sikkim", but data on the label of the only specimen in $\mathrm{G}$ is different, Kurseong in West Bengal. The same was stressed by Vána \& Long (2009).Váňa in litt. recognized this specimen as isotype, however, the species description is based on this specimen, but not on the specimen in V. Schiffner collection in $\mathrm{FH}$, because Stephani prepared descriptions basing on material of his collection, but not on duplicates in other herbaria. Most probably, the cited specimen is the one upon which the Stephani description of Jungermannia sikkimensis has been done. The disagreement between 

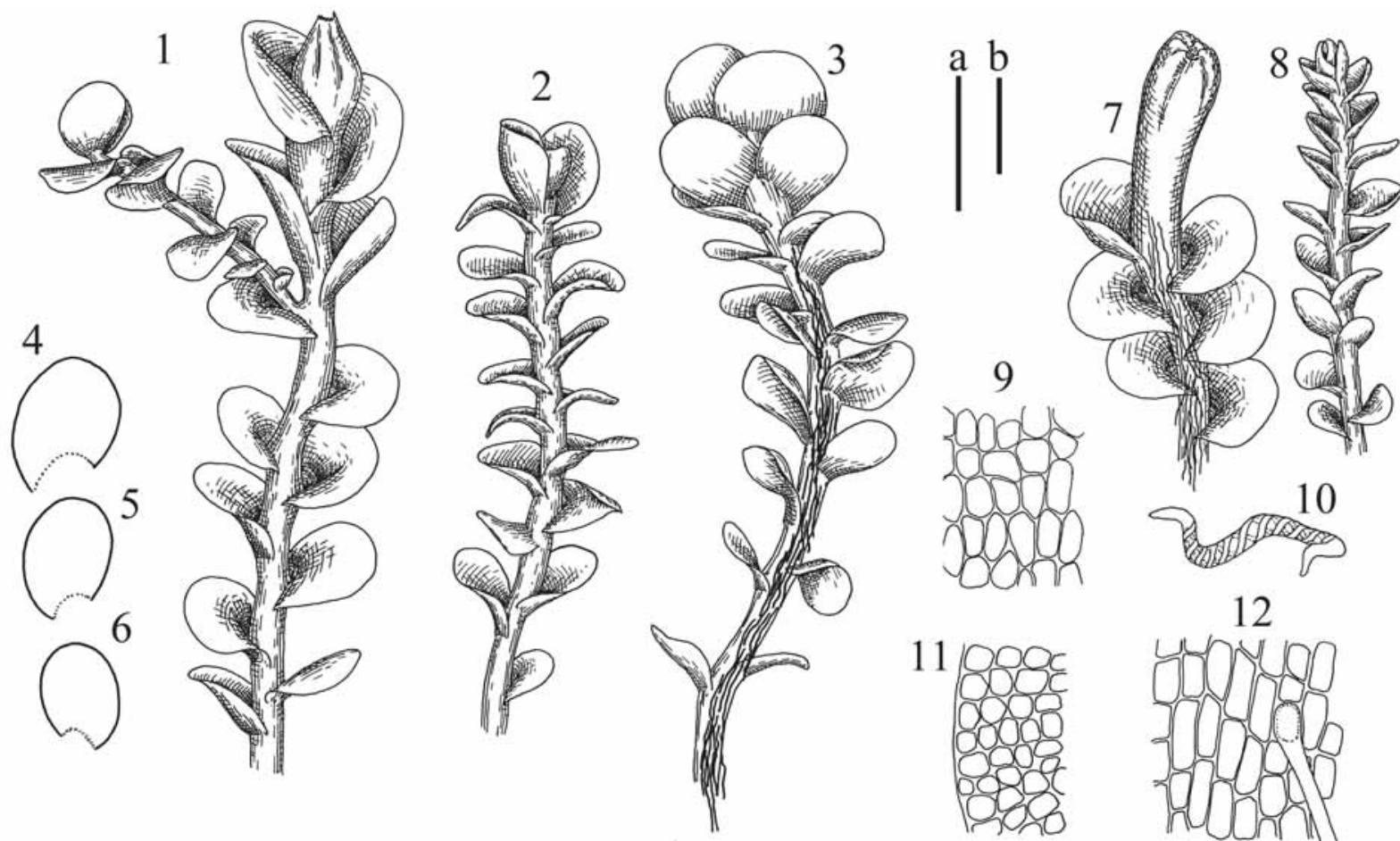

Fig. 16. Jungermannia sikkimensis Steph., neotype (G548/00115079): 1 - periathous plant; 2 - plant habit; 3 - plant habit, ventral view; 4-6 - leaves; Jungermannia simplicissima Steph., holotype (G14488/00067149): 7 - upper part of perianthous plant; 8 - plant habit; 9 - midleaf cells; 10 - elater; 11 - cells along leaf margin; 12 - rhizogenous cells in the leaf. Scales: a - 1 $\mathrm{mm}$, for $1-8 ; \mathrm{b}-100 \mu \mathrm{m}$, for $9,11,12 ; \mathrm{b}-50 \mu \mathrm{m}$, for 10 .

the label and the protologue seems to be caused by error, which, however, I cannot explain. Therefore I propose this specimen to be the neotype, not the holotype or isotype.

Accepted name: Plectocolea sikkimensis (Steph.) Bakalin comb. nov. Basionym: Jungermannia sikkimensis Steph., Sp. Hepat. 6: 92. 1917.

Description. Plants ascending to erect, in loose patches, brownish-green, without red or purple pigmentation, $1.25-2.5 \mathrm{~mm}$ wide and $10-15 \mathrm{~mm}$ long. Stem $225-375$ $\mu \mathrm{m}$ in diameter, slightly flexuous, not branched, with the exception of subfloral lateral innovations (very common, 1-2 per perianth). Rhizoids numerous, originated mostly near ventral leaf base, but not only there, decurrent down along the stem and forming distinct fascicle, colorless to grayish. Leaves obliquely to (larger plants) erect spreading, contiguous to rather distant, concave to concave-canaliculate, commonly with recurved (mostly slightly) dorsal margin, subtransversely to transversely inserted, dorsally shortly or up to $1 / 2$ of stem width decurrent, ventrally arcuately inserted, variously, but not longer that 1.0 stem width decurrent, obliquely ovate to orbicular, 700-960×750-1100 $\mu \mathrm{m}$. Midleaf cells 37.5$56.5 \times 27.5-37.5 \mu \mathrm{m}$, thin-walled, trigones moderate to large, cuticle loosely papillose; cells along leaf margin $20.0-27.5 \mu \mathrm{m}$, mostly thin-walled, rarely unequally thickened, trigones large, sometimes confluent in tangential wall, external wall thickened, cuticle slightly verrucose. Dioicous? Perianth conical, pluriplicate (mostly with 45 main plicae), ca. $1000 \times 750 \mu \mathrm{m}$, hidden within bracts or exerted for $1 / 3-1 / 2$ of its length; perigynium $2 / 2-3 / 2$ of perianth length, strongly rhizogenous (sometimes even dorsally!); female bracts similar to leaves or rarely retuse at apex. (Fig. 16: 1-6).

Comment. Váňa et al. (2013) synonymyzed recently described Plectocolea yunnanensis Bakalin (Bakalin, 2013) with P. sikkimensis, stating that the former species is fully identical with Solenostoma sikkimense (Schiffn. ex Steph.) Váňa et D.G. Long. Plectocolea yunnanensis however differs from $P$. sikkimensis in: 1) plant coloration (brownish-green versus pale greenish to greenish-yellowish, despite the fact that the type of P. sikkimensis is much older than P. yunnanensis and might be much paler colored due to age),2) short perigynium (less than $1 / 2$ of the perianth length versus higher than perianth length), 3) obliquely versus subtransversely to transversely inserted leaves, 4) obscurely thickened leaf cell walls versus uniformly thin (despite the fact trigones in the former are mostly small, but large in the latter). Differences in even part of these characters separate many species pairs in Plectocolea, e.g., Plectocolea subelliptica (Lindb ex Heeg.) A. Evans and P. obovata (Nees) Mitt., or other recognized by Váňa as discrete taxa, such pairs as Jungermannia hokkaidensis Váňa and J. subtilissima (Schiffn.) Grolle, Solenostoma ovalifolium (Amak.) Váňa and S. obscurum (A. Evans) R.M. Schust. and many others.

43) Jungermannia simplicissima Steph., Kungl. Svensk. Vetensk. Handl. 46(9): 171911. 
Holotypus: Chili. Chiloe 1908. Halle et Skottsberg G14488/00067149.

Accepted name: ?Solenostoma crassulum (Nees et Mont.) Steph.

Description. Plants erect in dense patches to ascending, greenish-yellowish to brownish-greenish, sterile $0.75-1.0 \mathrm{~mm}$ wide, female up to $2.0 \mathrm{~mm}$ wide, $4-8 \mathrm{~mm}$ long. Rhizoids rare, absent in the most of sterile plants, rarely present, obliquely spreading or decurrent down the stem in unclear fascicle, in female plants rhizoids common, brownish, decurrent down the stem in distinct fascicle in dorsal side of stem. Stem $125-175 \mu \mathrm{m}$ in diameter, not branched, with the exception of rare subfloral lateral innovations (1-2 per perianth), yellowish-brownish, straight. Leaves transversely to subtransversely inserted (obliquely in female plants), barely or up to $1 / 5$ of stem width decurrent dorsally and arcuately inserted and up to $1 / 2$ of stem width decurrent ventrally, concave to canaliculate-concave, obliquely to erect spreading, elliptic (smaller) to suborbicular (larger), 500-800 $\times 500-950$ $\mu \mathrm{m}$. Midleaf cells oblong, $25.0-45.0 \times 12.5-25.0 \mu \mathrm{m}$, thinwalled, trigones moderate in size, slightly convex, cuticle papillose; cells along leaf margin $25.0-27.5 \mu \mathrm{m}$, thin-walled, with thickened external wall, trigones moderate, convex. Dioicous. Perianth fusiform to (rarely) clavate, loosely 3-4plicate near mouth, gradually narrowed to not beaked mouth, ca. $2200 \times 500 \mathrm{~mm}$, composed by subisodiametric cells, bistratose and rhizogenous in lower $1 / 3$; perigynium virtually absent; bracts similar to larger leaves. Spores rusty brown, finely papillose, ca. $12.5 \mu \mathrm{m}$ in diameter. Elaters bispiral, ca. $125 \times 7 \mu \mathrm{m}$, with long (ca. 18-23 $\mu \mathrm{m}$ ) homogenous ends. (Fig. 16: 7-12).

Comments. a) Váňa (1974a) treated Jundermannia simplicissima as synonymous with $J$. crassula Nees et Mont (= Solenostoma crassulum (Nees et Mont.) Steph.), although noted that at the first sigh it seems an independent species due to ascending stem, distant leaves and clavate to fusiform perianth, but further studies revealed transitional forms to the typical $S$. crassula. By now and very preliminary I agree with Váňa's (1.c.) statement, but this question needs further studies involving more material.

b) Female plants are characterized by noticeable interesting rhizoid distribution, a feature rarely occurring in some species of Solenostoma. The rhizoids are decurrent down not by ventral side of stem, but along the dorsal side, that is very unique in prostrate to ascending growth form of these plants (not erect where probably "no difference for rhizoids" between ventral and dorsal sides is observed).

44) Jungermannia spongiosa Steph., Sp. Hepat. 6: 92. 1917.

Lectotypus nov.: Japan. 1907. Jishiba. G16632/ 00120740 .

Accepted name: Plectocolea spongiosa (Steph.) S. Hatt., Bull. Tokyo Sci. Mus. 11: 38. 1944.

Description. Plants prostrate to ascending, (1.5)2.0$3.5 \mu \mathrm{m}$ wide, $10-20 \mathrm{~mm}$ long, in loose patches, pallid, pale yellowish-brownish to whitish-brownish, more deeply (brownish to almost brown, rarely reddish-brownish) colored at leaf margins in upper part of shoot. Stem 250 375 (wider near perianth) $\mu \mathrm{m}$ in diameter, slightly flexuous, not branched, with the exception of ventral and lateral subfloral innovations (1-2 per perianth), becoming into normal branch. Rhizoids sparse, colorless to brownish, obliquely spreading (separated or in indistinct fascicles) or decurrent down the stem, but not forming distinct fascicle. Leaves contiguous, loosely concavecanaliculate, slightly undulate at the margin, or margin flat, obliquely spreading or loosely laterally appressed to the stem, suborbicular to widely ovate, $1500-2000 \times 1600$ $2100 \mu \mathrm{m}$, obliquely inserted, dorsally barely (smaller) or up to $1 / 2$ (larger) of stem width decurrent, ventrally arcuately inserted, not or barely decurrent. Midleaf cells oblong to subisodiametric, $62.5-94.0 \times 37.5-50.0 \mu \mathrm{m}$, thin-walled, trigones moderate to small, convex, cuticle distinctly papillose; leaf cells along margin $31.1-50.0$ $\mu \mathrm{m}$, thin-walled, trigones moderate to small, convex to concave, external wall slightly thickened, cuticle papillose. Dioicous. Perianth hidden within bracts (bracts ca. 1.5-2.0 times longer than perianth), conical, pluriplicate, not turbinate at the mouth, $1000 \times 500 \mu \mathrm{m}$, composed by elongated cells; perigynium ca. $1 / 2$ of perianth length; bracts undulate and sometimes loosely crispate at margin. (Fig. 17: 1-4).

Comments. a) There are two syntypes with the same label in G. The selected lectotype has better preserved plants and fits well the original description. The second syntype (G00120750) also belongs to the same species.

b) Amakawa (1960) treated this name as synonymous with J. torticalyx Steph. (= Plectocolea torticalyx (Steph.) S. Hatt.). I cannot agree with this. Both taxa differ in coloration (pale in P. spongiosa and deep in P. tortica$l y x$ ), rhizoid coloration (mostly purple and rigid in $P$. torticalyx and soft and colorless to brownish in P. spongiosa) and perigynium height (more than perianth length in P. torticalyx and $1 / 2$ of perianth length in $P$. spongiosa). Note that Amakawa (1960) indicated perigynium length for $J$. torticalyx as $1 / 2$ of perianth length, but the drawn perigynium (fig. 16 in 1.c.) exceeded the whole perianth length. The drawings well agreed with the type of $J$. torticalyx (see below).

c) In my opinion, $P$. spongiosa is most closely related to P. grossitexta (Steph.) S. Hatt., being different from the latter in larger leaves and leaf cells, as well as leaves wider than long. The relationships between both species need further consideration.

d) In the original description (Stephani, 1917), the perianth size is $7.5 \times 2.5 \mathrm{~mm}$, that is unimaginable, the real size is just $1.0 \times 0.5 \mathrm{~mm}$.

e) Another specimen of Jungermannia spongiosa (G16631/00120750) contains plants with olive brownish to blackish-greenish, and probably collected in water. Other parameters are similar to the lectotype. 

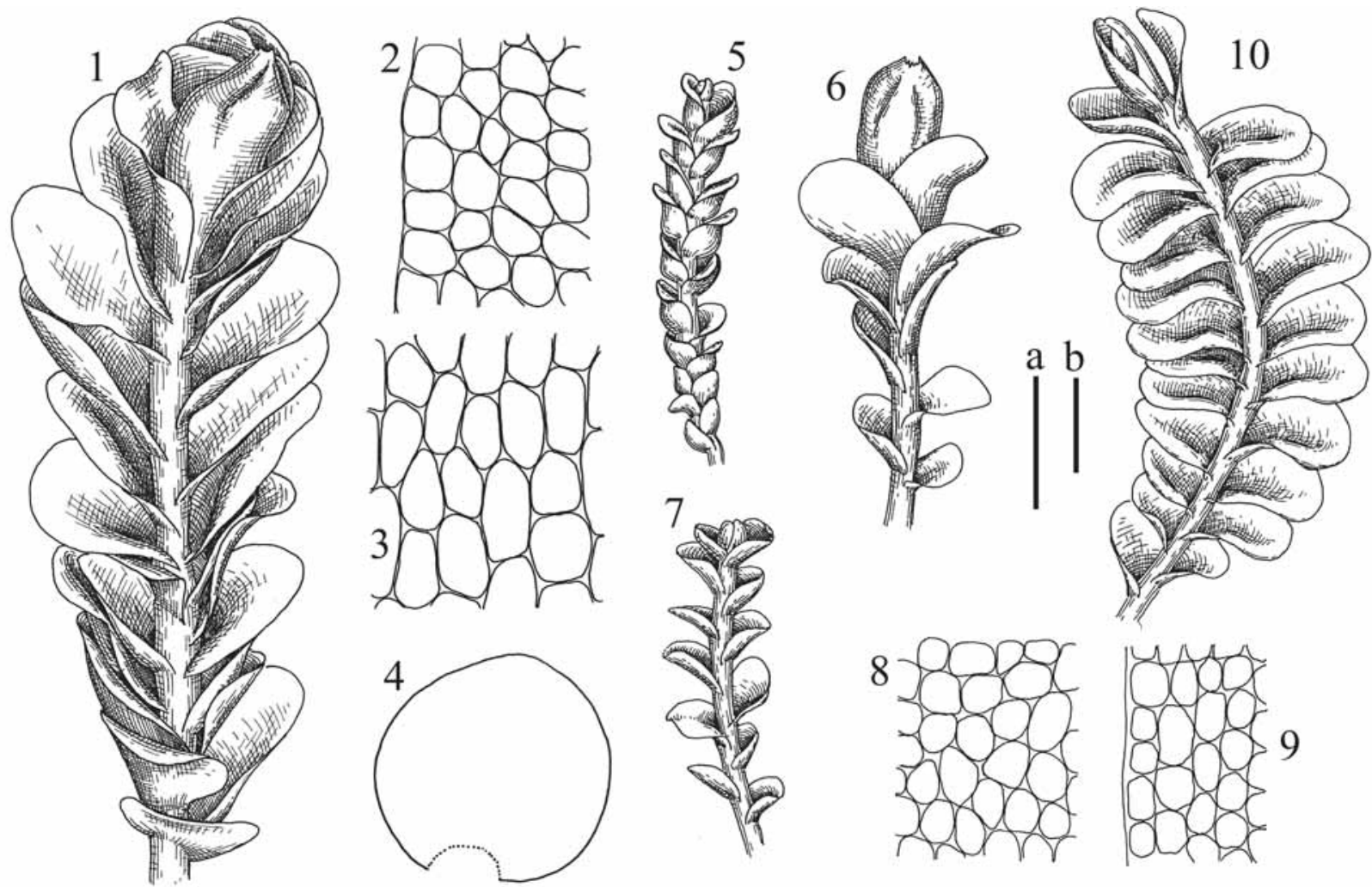

Fig. 17. Jungermannia spongiosa Steph., lectotype (G16632/00120740): 1 - perianthous plant; 2 - cells along leaf margin; 3 - midleaf cells, 4 - leaf; Jungermannia subrubra Steph., holotype (G677/115433): 5 - male plant; 6 - perianthous plant; 7 - plant habit; 8 - midleaf cells; 9 - cells along leaf margin; Jungermannia stevensiana Steph., holotype (G 644/00115332): 10 - plant habit. Scales: $\mathrm{a}-1 \mathrm{~mm}$, for $1,4-7,10 ; \mathrm{b}-100 \mu \mathrm{m}$, for $2,3,8,9$.

45) Jungermannia stevensiana Steph., Sp. Hepat. 6: 93. 1917.

Holotypus: India. Sikkim (Darjeeling) 1895. Stevens (No. 24)G 644/00115332.

Accepted name: Plectocolea comata (Nees) S. Hatt., Bull. Tokyo Sci. Museum 11: 38. 1944.

Comment. This name was synonymyzed with Jungermannia comata Nees (= Plectocolea comata (Nees) S. Hatt.) by Ván̆a (1972b), with whom I agree in full. (Fig. 17: 10)

46) Jungermannia subrubra Steph., Sp. Hepat. 6: 93. 1917. (= Nardia subrubra Schiffn. in litt.).

Holotypus: India. Sikkim. 2195 m a.s.1. 19.X.1899 Decoly et Schaul G677/115433 (In Sp. Hepat. 1917, W. Gollan mistakenly indicated as collector).

Accepted name: Solenostoma subrubrum (Stephani) Váňa \& D.G. Long, Nova Hedwigia 89: 508. 2009.

Description. Plants erect, greenish-brownish to pale brownish with purplish to violet tint near the perianth base and in its upper part (but not between these parts), 0.9-2.0 $\mu \mathrm{m}$ wide, $5-10 \mathrm{~mm}$ long. Stem 100-225 $\mu \mathrm{m}$ in diameter, brownish, not branched. Rhizoids numerous, brownish to pale purplish-brownish, decurrent down the stem and mostly forming clear fascicle, originated from ventral side of stem. Leaves obliquely to (rarer) erect spreading, concave-canaliculate, sometimes recurved away from the apex, contiguous to subimbricate, subtransversely inserted, dorsally decurrent for $1 / 2-2 / 3$ of stem width, ventrally subtransversely to arcuately inserted, not or up to $1 / 2$ of stem width decurrent, loosely undulate along margin, rounded to ovate, $550-1250 \times 600-1150 \mu \mathrm{m}$. Midleaf cells subisodiametric to oblong, 32.5-56.5 $\times 32.5-40.0 \mu \mathrm{m}$, thin-walled, trigones moderate in size, convex, cuticle smooth, cells along leaf margin $27.5-44.0 \mu \mathrm{m}$, mostly thin-walled, with slightly thickened external wall, trigones moderate in size to large, sometimes confluent in tangential walls, cuticle smooth. Dioicous. Androecia intercalary (although sometimes branch depauperate and die out after them), with 34 pairs of bracts, bracts strongly inflate in lower $1 / 3$ and recurved in upper $1 / 4$. Perianth subclavate, (3)4-plicate in upper half, gradually to suddenly contracted to not beaked mouth, composed by subisodiametric to shortly oblong cells; perigynium vestigial or up to $1 / 6$ of perianth length; female bracts similar to leaves, concave-canaliculate, recurved from the perianth in upper $1 / 3$ and sheathing perianth in lower third. (Fig. 17: 5-9).

47) Jungermannia tenerrima Steph., Sp. Hepat. 6: 93. 1917.

Holotypus: India. Missouri, Respana Valley. IX.1900 W. Gollan G645/00067148.

Accepted name: Plectocolea gollanii (Steph.) Bakalin, Arctoa 23: 101. 2014. 

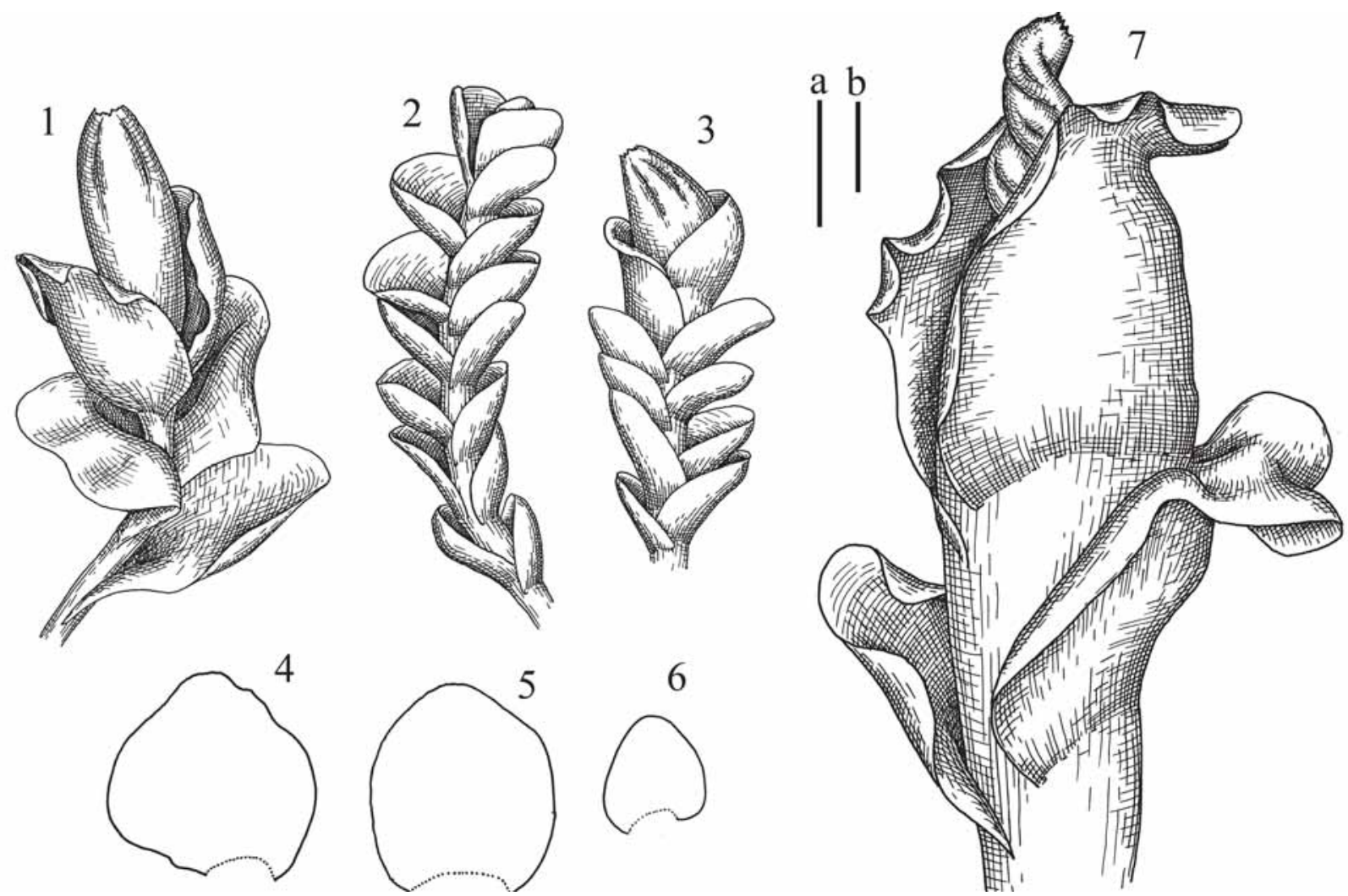

Fig. 18. Jungermannia tenerrima Steph., holotype (G645/00067148): 1 - perianthous plant; Jungermannia thermarum Steph., neotype (G00067147): 2 - plant habit, 3 - perianthous plant; Jungermannia torticalyx Steph., holotype (G16633/00067146): 4-6 leaves; 7 - upper part of perianthous plant. Scales: a $-1 \mathrm{~mm}$, for $1-6$; a $-500 \mu \mathrm{m}$, for 7 .

Comment. Váňa (1972a) synonymized J. tenerrima with $J$. gollanii Steph. (=Plectocolea gollanii (Steph.) Bakalin). I also do not see the differences from P. gollanii. Very characteristic is the perianth shape with wide mouth that is identical with $P$. gollanii and not present in other species of the genus (perianth middle cells 75.0 $112.5 \times 18.8-25.0 \mu \mathrm{m}$, thin-walled, with vestigial to wanting trigones, bistratose in lower $1 / 3(1 / 2)$ of the length). Perianth features also confirm position of the species in Plectocolea, but not in Jungermannia s. str. (see discussion under P. gollanii). (Fig. 18: 1).

48) Jungermannia thermarum Steph., Sp. Hepat. 2: 77. 1901.

Neotypus novus: Japan. Hakkoda. Eaux thermals. U. Faurie (No. 12791) G00067147.

Accepted name: Plectocolea vulcanicola (Schiffn.) Bakalin comb. nov. Basionym: Nardia vulcanicola Schiffn., Denkschr. Akad. Wiss. Wien, KI. Math.-Naturw. 67: 191. 1899.

Description. Plants blackish to brownish black, pellucid, rather erect to (rarer) ascending, in loose patches, 1.5$2.0 \mathrm{~mm}$ wide and $8-15 \mathrm{~mm}$ long, no red or purple pigmentation. Stem $250-300 \mu \mathrm{m}$ in diameter, blackish-brown, not branched. Rhizoids sparse, obliquely to erect spreading, rarely forming the mat at the ventral side of the stem, colorless to grayish. Leaves obliquely inserted (35-45? with axis), concave to canaliculate-concave, dorsally shortly or up to $1 / 4$ of stem width decurrent, ventrally arcuately inserted, not or shortly (less than $1 / 5$ of stem width) decurrent, transversely elliptic to suborbicular, ca. $1000 \times 1400$ $\mu \mathrm{m}$. Midleaf cells oblong, $50.0-87.5 \times 25.0-47.5 \mu \mathrm{m}$, thinwalled, walls brownish, trigones small, concave, cuticle smooth; leaf cells along margin 31.5-75.0 $\mu \mathrm{m}$, thin-walled, with external wall obscurely thickened, trigones small to moderate in size, convex to concave, cuticle virtually smooth. Dioicous. Perianth pluriplicate, with 5 main plicae, conical, ca. $1000 \times 700 \mu \mathrm{m}$, not turbinate at mouth, commonly with 1-2 subfloral innovations, composed by strongly elongated cells. Perigynium well-developed, 1/2-2/2 of perianth length; female bracts in 2 pairs on perigynium, similar to leaves, but wider, concave. (Fig. 18: 2, 3).

Comments. a) Original description (Stephani, 1901) cites locus classicus as "Sikayu (Faurie)", that probably means Sikayu Hot Spring in Akita Prefecture. That specimens could not be located in G, but only one from Hakkoda (Aomori Prefecture of Japan), also collected by U. Faurie was found. Since the specimen fits well into original description of Jungermannia thermarum, I suggest to designate it as neotype. It is worth noting that Amakawa (1960) cites locus classicus also as Hakkoda Mt. in Aomori Prefercture, despite the discrepancy with original description of collecting place in Stephani (1901).

b) Váňa (1974d) argued the synonymy of $J$. thermarum with $J$. vulcanicola (Schiffn.) Steph., with which I agree. 

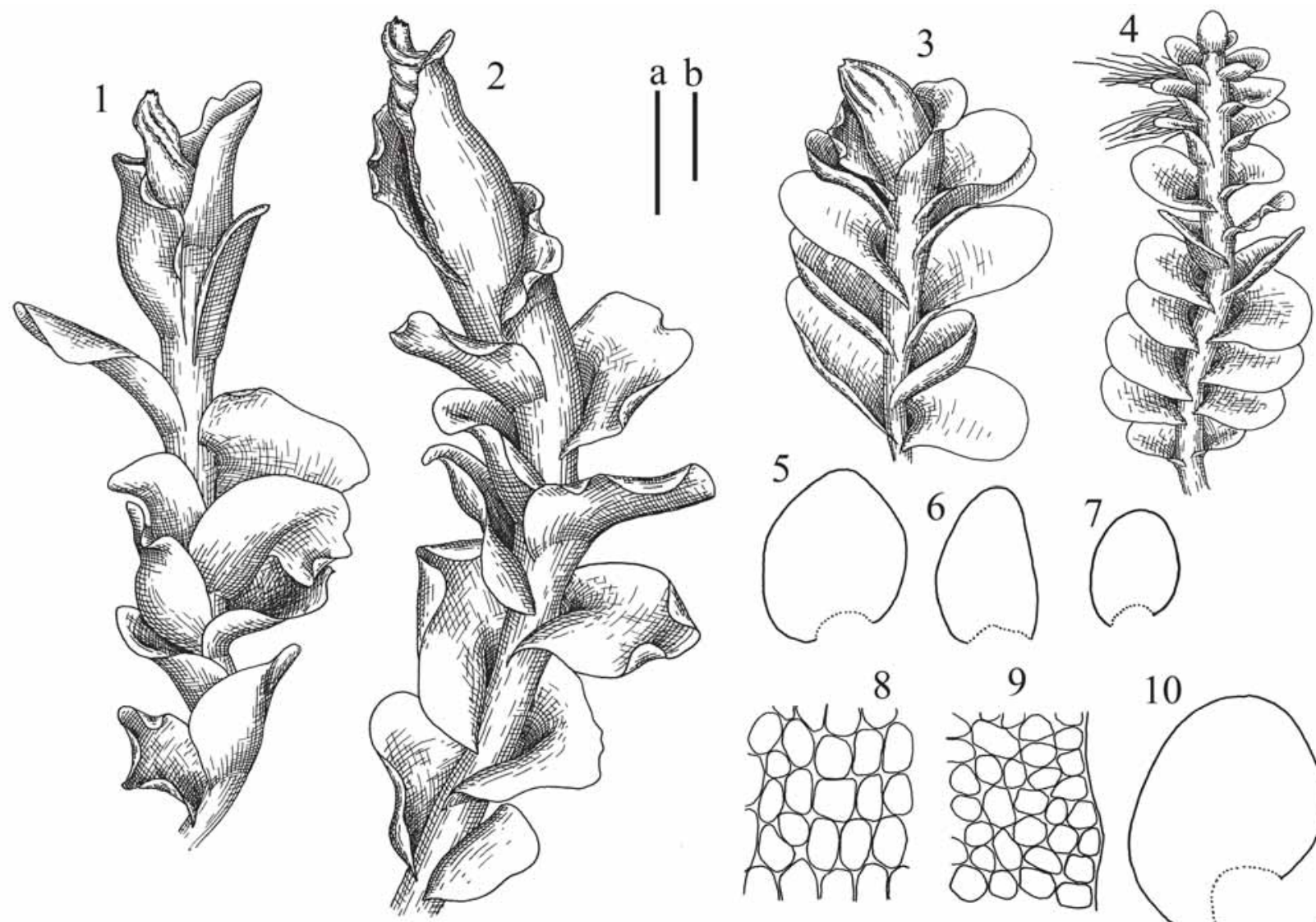

Fig. 19. Jungermannia torticalyx Steph., holotype (G16633/00067146): 1, 2 - perianthous plants; Jungermannia vaginans Steph., holotype (G16634/00067145): 3 - perianthous plant; 4 - plant habit; 5-7 - leaves; Nardia obliquifolia Schiffn., isotype (G14667/00115154): 8 - midleaf cells; 9 - cells along leaf margin; 10 - leaf. Scales: a - $1 \mathrm{~mm}$, for 1-7; b - 125 $\mu \mathrm{m}$, for 8, 9; a $1250 \mu \mathrm{m}$, for 10 .

c) The name "Plectocolea vulcanicola Schiffn." was used many times in the Russian literature (Konstantinova et al., 1992; Konstantinova et al., 2009, etc.), but it seems that has never been validated (Schiffner never published or mentioned this name in herbarium labelling); the necessity of validation is explained by the new combination above. 1917.

49) Jungermannia torticalyx Steph., Sp. Hepat. 6:94.

Holotypus: Japan. Hirafu. 1907. U. Faurie (No. 1923) G16633/00067146.

Accepted name: Plectocolea torticalyx (Steph.) S. Hatt., Bull. Tokyo Sci. Museum 11: 38. 1944.

Description. Plants large, erect, to ascending in loose patches, $2.0-4.0 \mathrm{~mm}$ wide and $8-20 \mathrm{~mm}$ long, greenishbrownish to brown in upper leaves margin and perianth tip, rigid. Stem brownish, $250-450 \mu \mathrm{m}$ in diameter (wider near perianth), loosely flexuous or straight, not branched. Rhizoids sparse to common, obliquely to erect spreading, not forming the fascicle, but sometimes united into mat, rigid, mostly purple, but some isolated colorless (mixed with purple ones). Leaves contiguous, obliquely to erect spreading, concave, commonly undulate at mar- gin, dorsally decurrent for $1 / 4-1 / 2$ of stem width, ventrally arcuately inserted, not or barely decurrent, widely ovate to widely triangular, $1000-1750 \times 1000-2000 \mu \mathrm{m}$ (1:0.9-1.0), concave to concave-canaliculate. Midleaf cells shortly oblong, $37.5-62.5 \times 22.5-37.5 \mu \mathrm{m}$, thinwalled, walls brownish to brownish-yellowish, trigones moderate, mostly concave, but sometimes slightly convex, cuticle smooth; cells along leaf margin 25.0-31.0 $\mu \mathrm{m}$, thin-walled, walls brownish yellowish or sometimes discolored, trigones moderate, convex, external wall thickened, cuticle virtually smooth. Dioicous. Perianth conical, pluriplicate (plicae more deeply, commonly brown, colored), mostly with 4-6 main plicae, distinctly turbinate at the mouth, $1250 \times 1000 \mu \mathrm{m}$; perigynium well developed, 3/2-4/2 of perianth length, with 2 pairs of bracts; female bracts similar to leaves, but wider, sheathing perianth and recurved in upper $1 / 3$, strongly undulate and shallowly crispate along margin. (Fig. 18: 4-7; 19: 1,2)

50) Jungermannia vaginans Steph., Sp. Hepat. 6: 95. 1917.

Holotypus: Japan. Sendai. 27.X.1907. E. Uematsu G16634/00067145. 
Accepted name: Plectocolea infusca Mitt., Trans. Linn. Soc. London, Bot. 3: 196. 1981. var. infusca

Description. Plants prostrate to ascending, closely to loosely attached plants to the substratum by rhizoids, greenish-brownish to brownish-green, 1.75-3.0 mm wide (male smaller, female larger), 5-7 mm long. Rhizoids numerous, brownish to purplish, erect to obliquely spreading in indistinct fascicles, or decurrent down the stem, but not forming distinct fascicle. Stem $225-275 \mu \mathrm{m}$ in diameter, sometimes slightly flexuous, not branched (even as subfloral innovations). Leaves contiguous, obliquely inserted, decurrent ca. 1/2-3/2 of stem width dorsally and arcuately inserted ventrally, where not or shortly (up to $1 / 4$ of stem width) decurrent, concave-canaliculate, at middle part sometimes (larger ones) convex, obliquely ovate to obliquely ovate and obliquely lingulate, 1000$1400 \times 850-1450 \mu \mathrm{m}(1: 0.8-1.1)$. Midleaf cells oblong, $35.0-62.5 \times 25.0-37.5 \mu \mathrm{m}$, thin-walled, trigones moderate, convex, cuticle papillose; leaf cells along margin 21.0-35.0 $\mu \mathrm{m}$, thin-walled, trigones moderate, convex, external walls thickened, cuticle virtually smooth. Dioicous. Perianth conical, pluriplicate, loosely turbinate at the mouth, composed by shortly elongated cells, $1250 \times 750 \mu \mathrm{m}$, exerted for $1 / 3-1 / 2$ of its length; perigynium ca. $1 / 3$ of perianth length; female bracts similar to leaves, sheathing perianth near the base and obliquely spreading above. Androecia intercalary (although sometimes branch become depauperate or die out after androecia), with 2-3 pairs of bracts, bracts similar to leaves, but strongly inflated at lower half and with recurved margin. (Fig. 19: 3-7)

Comment. The plants in holotype are fully identical with $P$. infusca. The synonymyzation of two names was made before by Ván̆a (1975c), with whom I agree.

51) Jungermannia wattsiana Steph., Sp. Hepat. 6: 99. 1917.

Lectotypus (selected by Váňa, 1975a): Australia. NS. Wales. 24.VI.1901 R. Watts (No. 303) G14307/ 00067143.

Accepted name: Plectocolea montana (Steph.) Bakalin, Arctoa 23: 102. 2014.

Description. Plants prostrate, pallid, pellucid, pale brownish green to brownish, loosely attached to the substratum, 1.25-2.0 (up 2.5 near perianth) $\mathrm{mm}$ wide and 5-8 mm long, dorsiventrally flattened. Rhizoids sparse, erect spreading, colorless to purplish and purplish-brownish, originated from the stem. Stem brownish, sometimes slightly flexuous, $125-225 \mu \mathrm{m}$ in diameter, not branched (even as subfloral innovations). Leaves contiguous to distant, very obliquely inserted, dorsally decurrent for $1 /$ $2-2 / 2$ of stem width, ventrally transversely to arcuately inserted, not or barely decurrent, flattened to slightly convex (concave near the perianth), soft, undulate at margin, obliquely ovate, 750-1400×750-1300 $\mu \mathrm{m}$. Midleaf cells subisodiametric to shortly oblong, 35.0$62.5 \times 31.2-40.0 \mu \mathrm{m}$, thin-walled, trigones small, concave, cuticle distinctly papillose; cells along leaf margin 25.0 $34.0 \mu \mathrm{m}$, more or less thin-walled, with obscurely thickened external wall, trigones small, concave; cuticle obscurely verrucose-papillose. Dioicous? Perianth conical, loosely 3-pluriplicate, gradually narrowed to the mouth, composed by oblong cells, ca. $625 \times 375 \mu \mathrm{m}$, exerted for $1 / 2-2 / 3$ of its length; perigynium $1 / 2-2 / 3$ of the perianth length, with 1 pair of bracts; female bracts similar to large leaves, but wider, loosely sheathing perianth near base and recurved in upper $1 / 3$ of dorsal side, ventrally obliquely spreading. (Fig. 20: 1, 2)

Comments. a) Váňa (1975a) stated that among sympatric species the most closely related one is Jungermannia hirticalyx Steph. (= Plectocolea hirticalyx (Steph.) Bakalin), but the latter is larger in size, often ascending in growth form, with mostly larger and wider leaves, and larger leaf cells (1.c., 295: "Sie unterscheidet sich durch grossere, oft aufsteigende Pflanzen mit grosseren, moistens auch breiteren Blattern, grosserem Blattzellnetz u.a.m."). In fact, plants in the type specimens (cf. Jungermannia hirticalyx above) are only slightly different and plant size, leaf size as well as cell size are slightly larger in Jungermannia wattsiana (!) type (35.0-62.5×31.2-40.0 $\mu \mathrm{m}$ ), but not in $J$. hirticalyx type (where $25.0-44.0 \times 25.0$ $34.0 \mu \mathrm{m}$. This observation differs drastically from Váňa's (1975a) assertions. Superficially both taxa are very similar as well and I do not see any reasons to keep both taxa separately. Two more taxa synonymyzed with Jungermannia wattsiana Steph. (Ván̆a, 1975a) before are Nardia montana Steph. and Solenostoma australe Steph. I agree in full with the latter synonymyzing and thus need to note:

Plectocolea montana (Steph.) Bakalin, Arctoa 23: 102. $2014=$ Jungermannia wattsiana Steph. Sp. Hepat. 6: 99. 1917. syn. nov.

b) The plants in another examined specimen (not type, “Australia New South Wales. 11.VI.1901 R. Watts (No. 303)", G14311/00112016) named as Jungermannia wattsiana by Stephani are similar to lectotypus, but more deeply colored (brownish), not so pallid and have dense rhizoids, which are commonly purple, erect spreading and forming mat under stem.

52) Nardia dusenii Steph., Hedwigia 30: 209. 1891.

Holotypus: Congo (Bomana). On rocks and stones. 2.XII.1890 P. Dusen (No. 48) G14453/00115344.

Accepted name: Plectocolea dusenii (Steph.) Bakalin comb. nov. Basionym: Nardia dusenii Steph., Hedwigia 30: 209. 1891.

Description. Plants prostrate, slightly pellucid, forming loose mats, soft, $1.25-2.15 \mathrm{~mm}$ wide and 8-15 mm long, greenish-brownish, dorsiventrally flattened. Stem $175-250 \mu \mathrm{m}$ in diameter, not branched, with the exception of subfloral innovations. Rhizoids brown to purplishbrown and purplish-brownish, rather common, originated mostly near ventral leaf base, but not only there, decurrent down the stem and forming loose fascicle, or sep- 


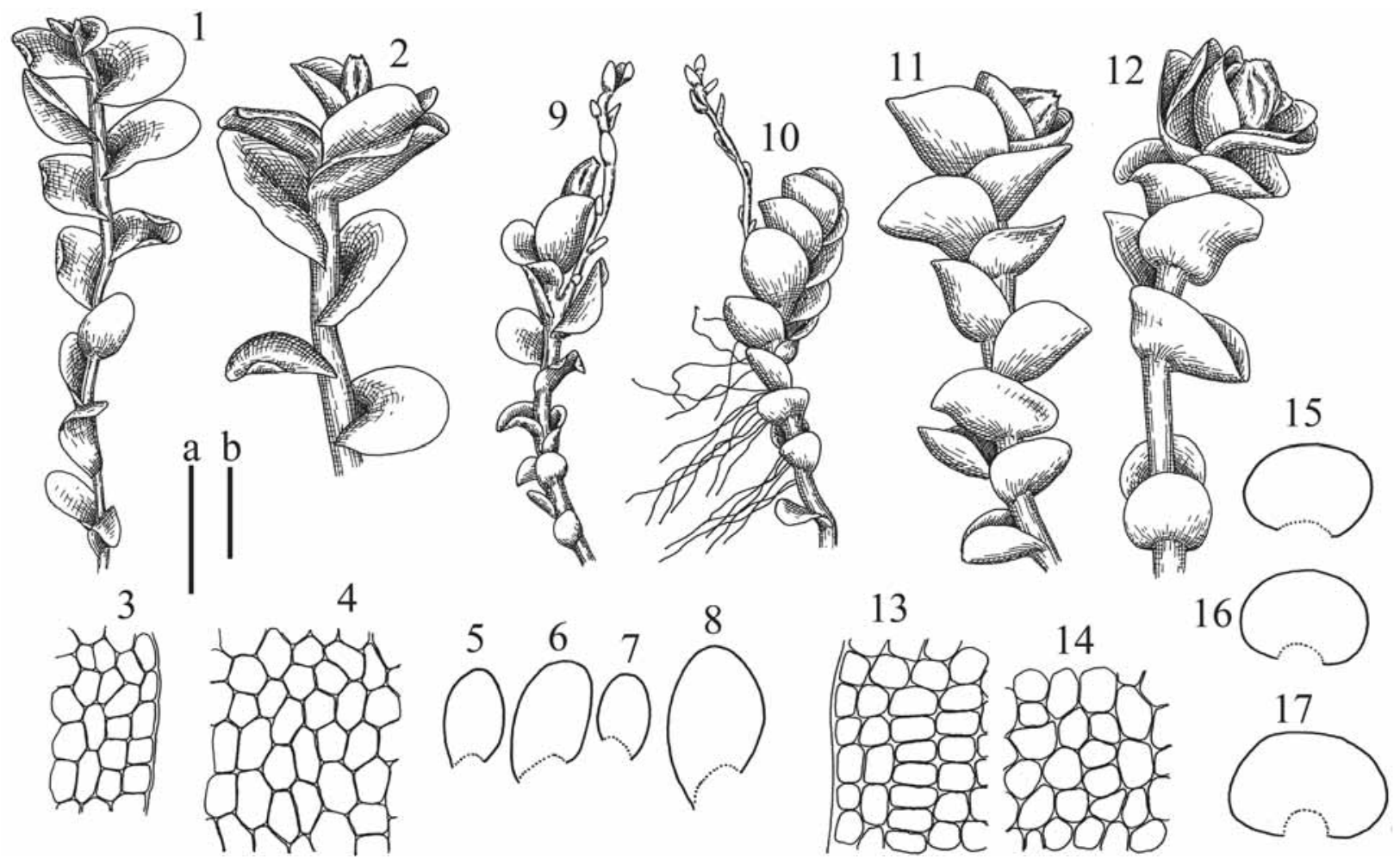

Fig. 20. Jungermannia wattsiana Steph., lectotype (G14307/00067143): 1 - plant habit; 2 - perianthous plant; Nardia dusenii Steph., holtype (G14453/00115344): 3 - cells along leaf margin; 4 - midleaf cells; 5-8 - leaves; Jungermannia coniflora Schiffn., isotype (G14494/00115333): 9 - perianthous plant; 10 - plant habit; Nardia levieri Steph., holotype (G11673/00067154): 11, 12 - perianthous plants; 13 - cells along leaf margin; 14 - midleaf cells; $15-17$ - leaves. Scales: a - $1 \mathrm{~mm}$, for 1, 2, 5-12, 15-17; b $-100 \mu \mathrm{m}$, for $3,4,13,14$.

arated and obliquely spreading. Leaves very obliquely inserted, laterally spreading, dorsally barely or up to $1 / 3$ of stem width decurrent, ventrally subtransversely to loosely arcuately inserted, not or barely decurrent, flattened to slightly convex, distant to contiguous, obliquely ovate, $600-1000 \times 450-800 \mu \mathrm{m}$. Midleaf cells shortly oblong, 31.0-56.0 $0 \times 22.5-32.5 \mu \mathrm{m}$, thin-walled, trigones vestigial to very small, concave, cuticle distinctly papillose; cells along leaf margin $25.0-37.5 \mu \mathrm{m}$, thin-walled, trigones very small, concave, cuticle distinctly papillose, leaf margin crenulate due to protrudent cells. Dioicous. Androecia seems to be intercalary, but not more than one generation was observed, with 10 and more pairs of bracts, 2-3-androus, male bracts similar to leaves, but inflated in lower $1 / 3$, concave-canaliculate, commonly with recurved dorsal leaf margin. Perianth conical to narrowly trapezoidal in projection, ca. $1900 \times 750 \mu \mathrm{m}$, shallowly pluriplicate, not turbinate, gradually narrowed to the narrow or wide (up to $600 \mu \mathrm{m}$ ) mouth, exerted for 2/5-3/ 5 of its length, composed by elongate, pellucid, thinwalled cells; perigynium ca. 1/5-1/3 of perianth length, with 1 pair of bracts, rhizogenous ventrally; female bracts similar to leaves, undulate at margin, sheathing perianth in lower $1 / 2$ and obliquely spreading above, commonly with dorsal margin recurved away of the perianth. (Fig. 20: 3-8; 21: 1-3).
Comment. The species is closely morphologically related to Plectocolea comata (Nees) S Hatt., but differs mainly in rhizoid coloration and leaf cell features.

53) Nardia levieri Steph., Bot. Zentralblatt 13(50): 70. 1892 .

Holotypus: Svanetia occidentalis, ad rivulos alpinos jugi Utbiri. $2400 \mathrm{~m}$ a.s.1. 19.VIII.1890 Levier (No. 60) G11673/00067154.

Accepted name: Solenostoma levieri (Steph.) Steph., Sp. Hepat. 2: 50. 1901.

Description. Plants yellowish-brownish, erect in rather dense patches, $1.25-2.0 \mu \mathrm{m}$ wide and $8-12 \mathrm{~mm}$ long, lax, soft. Stem $225-300 \mu \mathrm{m}$ in diameter, not branched, even as subfloral innovations, yellowish brownish. Rhizoids nearly colorless to brownish, originated both from ventral side of stem and from lower half of the leaf lamina, decurved down along the stem and forming fascicle (sometimes unclear). Leaves loosely concave to concave-canaliculate, soft, sometimes undulate at margin, subtransversely inserted, shortly or up to $1 / 2$ of stem width decurrent dorsally and arcuately inserted and barely or up to $3 / 4$ of stem width decurrent ventrally, distant to contiguous, rarer subimbricate (in perianthous plants only), mostly erect spreading, transversely elliptic, 700-900×1200-1450 $\mu \mathrm{m}$. Midleaf cells subisodiametric to shortly oblong, 31.0- 
$44.0 \times 31.0-40.0 \mu \mathrm{m}$, thin-walled, trigones moderate in size, triangle to concave; cells along leaf margin 20.0$37.0 \mu \mathrm{m}$, thin-walled, with thickened external wall, trigones moderate in size, mostly concave, rarely slightly convex, cuticle smooth. Paroicous. Androecia with 2-3 pairs of bracts situated just below female bracts, similar to large leaves, loosely inflated in lower $1 / 3$. Perianth 4-5-plicate in upper $1 / 3-1 / 2$ of its length, gradually or (more frequently) suddenly contracted to the not or obscurely beaked mouth, exerted for $1 / 3-1 / 2$ of its length, obovate, $1000-1100 \times 900-1000 \mu \mathrm{m}$; perigynium virtually absent or up to $1 / 5$ of perianth length; female bracts similar to leaves, in one pair, loosely sheathing perianth and not or slightly obliquely spreading in upper 1/3-1/4. (Fig. 20: 11-17).

Comment. At the time of description Stephani (1892a) believed Nardia levieri Steph. (= Solenostoma levieri (Steph.) Steph.) is closely morphologically allied to Jungermannia lanigera Mitt. (= Solenostoma lanigerum (Mitt.) Váňa et D.G. Long) due to rhizogenous leaf cells. Later Nardia levieri was synonymyzed by Váňa (1974c) as "häufigste Modifikation" (1.c.: 376) under Jungermannia confertissima Nees (= Solenostoma confertissimum (Nees) Schljakov). I think that although Solenostoma levieri and S. confertissimum are related, they differ. The main differentiating features are absence of red or purplish coloration in $S$. levieri and shortly exerted perianth. The differences of $S$. levieri from $S$. confertissimum are of the same value as the differences of Lophozia wenzelii (Nees) Steph. var. wenzelii from var. massularioides Bakalin. The question whether S. levieri should be regarded as a variety within $S$. confertissimum, needs further investigation.

54) Nardia obliquifolia Schiffn., Denkschr. Akad. Wiss. Wien, KI. Math.-Naturw. 67: 191. 1899.

Isotypus: Sumatra occidentalis. In monte Singalang, in silvis primaevis ad decli. orient. Regio nubium. 2000 m a.s.1. 24.VII.1894 Schiffner (481) G14667/00115154.

Accepted name: Plectocolea obliquifolia (Schiffn.) Bakalin comb. nov. Basionym: Nardia obliquifolia Schiffn., Denkschr. Akad. Wiss. Wien, KI. Math.-Naturw. 67: 191. 1899.

Description. Plants erect, in dense patches, 1.6-2.75 $\mathrm{mm}$ wide and 12-20 mm long, yellowish-brownish, rigid. Stem $250-325 \mu \mathrm{m}$ in diameter, not branched, yellowish-brownish. Rhizoids numerous, purple to brownishpurple, originated mostly near ventral leaf base, but not only there, decurrent down in distinct fascicle, that is little bit smaller than stem. Leaves obliquely spreading, concave-canaliculate, transversely to subtransversely inserted, dorsally decurrent for $1 / 2-2 / 2$ of stem width, ventrally arcuately inserted, decurrent for $1 / 2$ of stem width, distant to contiguous, in larger shoots enclosed one to another; in shape rounded to transversely elliptic in smaller shoots and widely obliquely ovate to obliquely elliptic in larger ones, $750-1650 \times 1000-1750 \mu \mathrm{m}$, large leaves sometimes crispate at margin. Midleaf cells oblong, 37.5 $64.0 \times 21.0-37.5 \mu \mathrm{m}$, thin-walled, trigones moderate in size, concave to convex, cuticle distinctly striolate-papillose; cells along leaf margin 25.0-31.0 $\mu \mathrm{m}$, thin-walled, with thickened external wall, cuticle distinctly papillose, trigones moderate in size, mostly convex. Dioicous? Androecia looks intercalary (but no sequence of generations was observed) in 3-5 pairs of bracts, 2-3-androus, male bracts similar to leaves, but wider, evidently inflated in lower half, purplish in inflated area and nearby. (Fig. 19: 8-10; 21: 4-9).

Comment. Another isotype of Nardia obliquifolia Schiffn. (G00115153) is identical to the above descibed in all features.

55) Nardia prostrata Steph., Bull. Herb. Boissier 5: 101. 1897. (= Jungermannia prostrata (Steph.) Steph. Bull. Herb. Boissier, sér. 2, 1: 504. 1901, replaced by Jungermannia inouensis Beauverd in Steph. Sp. Hepat. 6: 569. 1924., non Jungermannia prostrata Sw. Nova Genera et Species Plantarum seu Prodromus 143. 1788.).

Holotypus: Japan. Yezo, Hakodate 1.V.1886 U. Faurie (No. 222) G516/00115364.

Accepted name: Plectocolea prostrata (Steph.) S. Hatt., Bull. Tokyo Sci. Mus. 11: 38. 1944.

Description. Plants erect, yellowish-brownish, in dense patches, $1.0-1.25 \mathrm{~mm}$ wide (rarely up $1.5 \mathrm{~mm}$ wide near perianth), $10-15 \mathrm{~mm}$ long. Stem $250-300 \mu \mathrm{m}$ in diameter, slightly wider near the perianth, not branched, even as subfloral innovations, yellowish-brownish (darker colored than leaves). Rhizoids numerous, originated from stem near ventral leaf base and 1-3 lowest rows of cells in the leaf, deep purple. Leaves distant to (in younger parts and near perianth) contiguous, obliquely spreading to loosely laterally appressed to the stem, slightly concave to nearly flattened or convex (in lower part of branch), in the latter case commonly with leaf apex recurved to stem base, subtransversely (rarely obliquely) inserted, dorsally decurrent for $1 / 2-3 / 2$ of stem width, ventrally shortly or up to $1 / 2$ of stem width decurrent, widely obliquely ovate, $700-800 \times 850-1000 \mu \mathrm{m}$. Midleaf cells $22.5-31.0 \times 22.5-25.0 \mu \mathrm{m}$, subisodiametric, walls unequally thickened (sometimes also thin), trigones moderate in size to large, convex, cuticle smooth; cells along leaf margin 27.5-31.0 $\mu \mathrm{m}$, unequally thickened, trigones large, sometimes confluent, external wall noticeable thickened, cuticle at the edge distinctly verrucose or not so. Dioicous? Perianth conical, slightly laterally compressed, ca. $650-1000 \times 1000-1100 \mu \mathrm{m}$, with 4 main plicae, composed by elongate and pellucid cells; perigynium 4/5-7/5 of perianth length, rhizogenous, with 2 pairs of bracts; female bracts similar to leaves, but undulate at margin, also sometimes emarginated at apex. (Fig. 12: 3-9).

Comment. This name was synonymyzed with $J$. virgata (Mitt.) Steph. (= Plectocolea virgata Mitt.) by Amakawa (1960). However, according to my observations, Nardia prostrata is different from Plectocolea vir- 

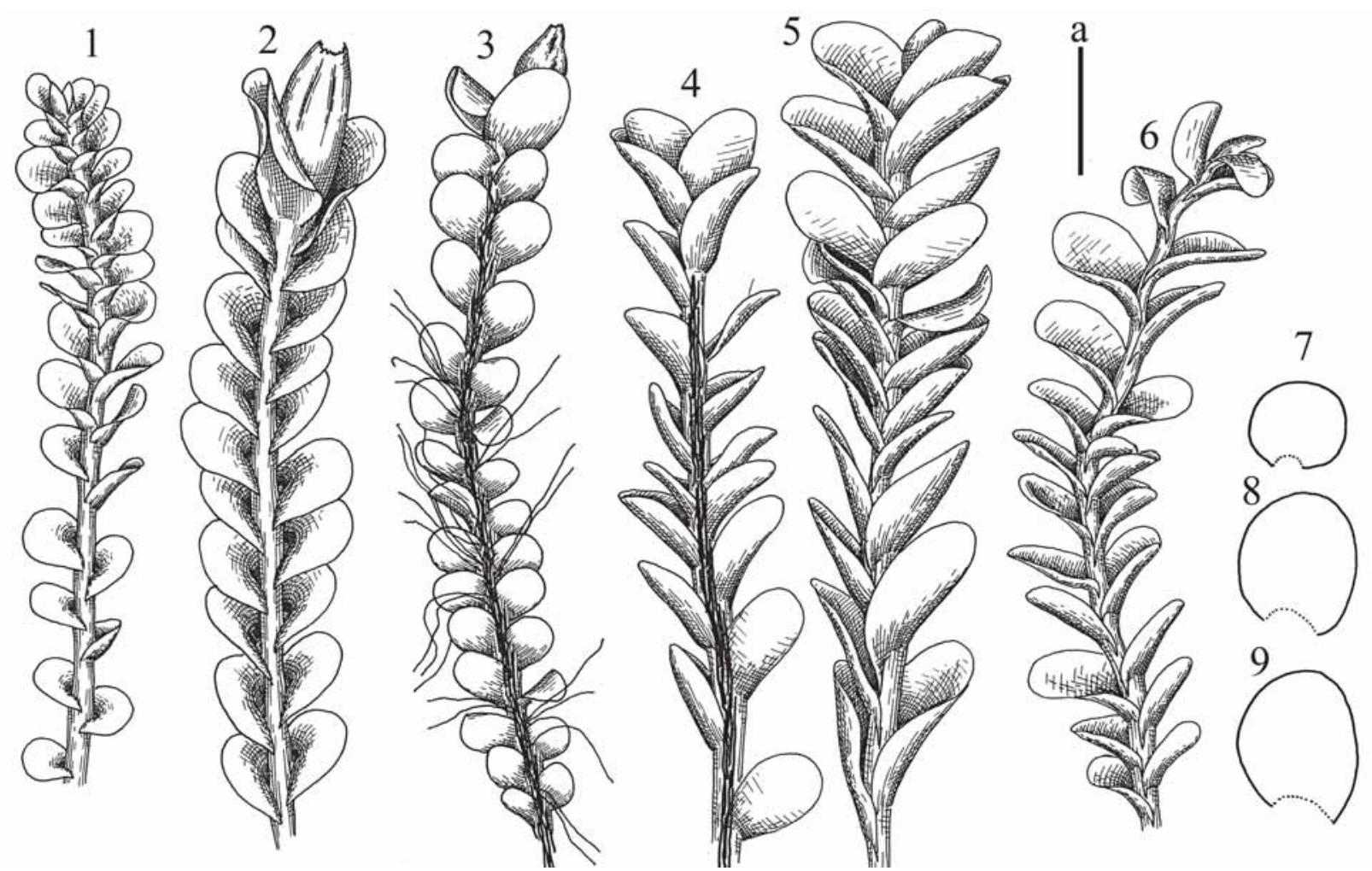

Fig. 21. Nardia dusenii Steph. Hedwigia 30: 209. 1891., holotype (G14453/00115344): 1 - plant habit; 2 - perianthous plant; 3 - perianthous plant, ventral view; Nardia obliquifolia Schiffn., isotype (G14667/00115154): 4 - plant habit, ventral view; 5, 6 - plant habit; 7-9 - leaves. Scale: a - 1,25 mm, for 1-9.

gata in leaf cell size (much larger in N. prostrata), size of trigones (large and convex in N. prostrata versus small and mostly concave in $P$. virgata). Due to features in the description based on the type material, $P$. erecta may be synonymized with $N$. prostrata, another species of "virgata" group, but now I refrain from this conclusion because of rhizoids in $N$. prostrata which originate from the limited area near ventral leaf base and from some lower cells in the basal part of the leaf. This feature should set $N$. prostrata aside of the pair $P$. virgata $-P$. erecta, and then $N$. prostrata may be treated as a separate species from them.

56) Nardia rosulans Steph., Bull. Herb. Boissier 5: 101. 1897.

Holotypus: Japan. Tosa. 1895 T. Inoue G16630/ 00067156.

Accepted name: Plectocolea rosulans (Steph.) S. Hatt., Bull. Tokyo Sci. Mus. 11: 38. 1944.

Description. Plants prostrate to rather ascending, dorsiventrally flattened, $2.5-2.8 \mathrm{~mm}$ wide, $15-20 \mathrm{~mm}$ long, in loose patches, green to brownish and yellowishgreenish. Rhizoids common, purple to purplish and purplish-brown, decurrent down the stem and forming distinct narrow fascicle, originated commonly near ventral leaf base. Stem 250-300 $\mu \mathrm{m}$ in diameter, brownish, not branched. Leaves obliquely inserted, dorsally shortly (up $1 / 4$ of stem width) decurrent, ventrally subtransversely to arcuately inserted, not or barely decurrent, leaves some- times (larger ones) undulate at margin, distant to contiguous, obliquely laterally spreading, concave-canaliculate, obliquely ovate, $1100-1500 \times 900-1400 \mu \mathrm{m}$. Midleaf cells subisodiametric to oblong, $27.5-50.0 \times 25.0-35.0 \mu \mathrm{m}$, thin-walled, cuticle smooth, trigones moderate in size, convex; cells along margin $12.5-26.5 \mu \mathrm{m}$, thin-walled, with moderate in size to large convex trigones, external wall thickened, cuticle smooth. (Fig. 22: 1, 2).

57) Nardia stolonifera Steph., Hedwigia 31: 128. 1892.

Lectotypus (selected by Váňa, 1974b): Transvaal. In jugo Mahali Mt., ad terra. Mac Lea (229) G14473/ 00112143.

Accepted name: Solenostoma stoloniferum (Steph.) S.W. Arnell, Hepaticae of South Africa, 316. 1963.

Description. Plants prostrate to ascending, pallid, pale greenish-brownish to whitish-brownish, more or less pellucid, forming rather dense mats, $0.4-0.6 \mathrm{~mm}$ wide (perianthous up to $1.6 \mathrm{~mm}$ wide) and $3-5 \mathrm{~mm}$ long, sometimes margins of upper leaves more dark colored. Stem $125-175 \mu \mathrm{m}$ in diameter, whitish to pale brownish, not branched, but commonly with ventral stolon-like rhizogenous scale-leaved branches that not become to normal branch. Rhizoids sparse to numerous, colorless to purplish, rarely purple, obliquely spreading. Leaves contiguous, concave to concave-canaliculate, obliquely spreading, large leaves undulate at margin, obliquely inserted, shortly (up to $1 / 2$ of stem width) decurrent dorsally, sub- 

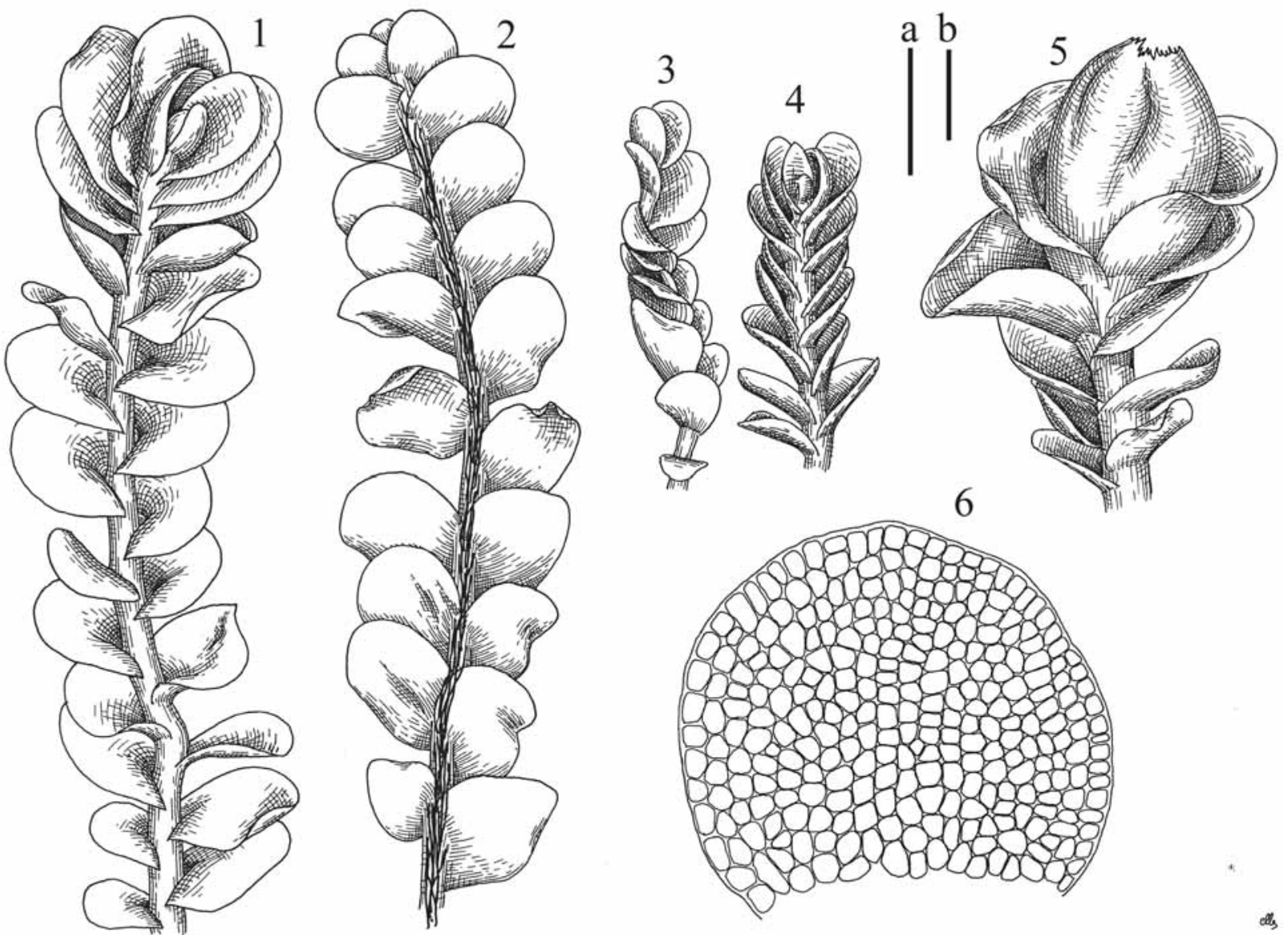

Fig. 22. Nardia rosulans Steph., holotype (G16630/00067156): 1 - plant habit; 2 - plant habit, ventral view; Nardia stolonifera Steph., lectotype (G14473/00112143): 3, 4 - plant habit; 5 - upper part of perianthous plant; 6 - leaf. Scales: a - 1, $25 \mathrm{~mm}$, for 1, 2 ; $\mathrm{b}-100 \mu \mathrm{m}$, for 6 ; $\mathrm{a}-500 \mu \mathrm{m}$, for $3-5$.

transversely to loosely arcuately inserted ventrally, where not or barely decurrent, suborbicular to transversely elliptic, 300-400×375-500 $\mu \mathrm{m}$. Midleaf cells 13.5$27.5 \times 15.0-22.5 \mu \mathrm{m}$, thin-walled, trigones moderate in size to small, concave, cuticle smooth; cells along leaf margin $12.5-29.0 \mu \mathrm{m}$, thin- to obscurely and unequally thick-walled, trigones moderate in size, concave, external wall thin, cuticle smooth. Dioicous. Perianth comparatively large (in comparison with sterile plants), ca. $1.5 \times 0.9 \mathrm{~mm}$, ellipsoidal to obovate, loosely 3 -plicate in upper half, gradually narrowed to not beaked mouth, exerted for $1 / 2-3 / 5$ of the length, composed by subisodiametric cells; perigynium ca. $1 / 4-1 / 5$ of perianth length, with one pair of bracts; female bracts undulate at margin, sometimes loosely crispate, sheathing perianth in lower half and obliquely spreading above, ca. $1000 \times 1150$ $\mu \mathrm{m}$. (Fig. 22: 3-6).

Comments. a) Nardia stolonifera Steph. (= Solenostoma stoloniferum (Steph.) S.W. Arnell) was synonymyzed with Jungermannia borgenii Gott. (=Solenostoma borgenii (Gott.) Steph.) by Váňa (1974b). However, the type of Nardia stolonifera differs considerably both from the description of Jungermannia borgenii provided by Váňa (1.c.) and from the original description of Nar- dia stolonifera (Stephani, 1892b). Size of plants is much smaller, with shoots being only $600 \mu \mathrm{m}$ wide (but become much wider near perianth where attain $1600 \mu \mathrm{m})$ and leaf cells are smaller $(13.5-27.5 \times 15.0-22.5 \mu \mathrm{m}$, versus $30-35 \mu \mathrm{m}$ in Solenostoma borgenii). Solenostoma stoloniferum was described one year earlier than Jungermannia borgenii, thus the correct name for this taxon should be the former one, regardless of whatever the taxa are synonymous or not.

b) The plants in the second specimen (syntype) found in $\mathrm{G}$ collection (G00112144) are rather similar with lectotype, but differ in presence of light rusty pigmentation of shoots.

58) Nardia verrucosa Steph., Hedwigia $31: 172.1892$.

Holotypus: Camerun. Prope Elundu pagus in rupicis basalticis adesis. 17.X.1980. Dusen (126B) G14478/ 00115343.

Accepted name: Plectocolea dusenii (Steph.) Bakalin comb. nov. Basionym: Nardia dusenii Steph., Hedwigia 30: 209. 1891.

Description. Plants prostrate, dorsiventrally flattened, $1.25-2.25 \mathrm{~mm}$ wide and 10-20 $\mu \mathrm{m}$ long, yellowishbrown, without red or purple pigmentation, forming loose 

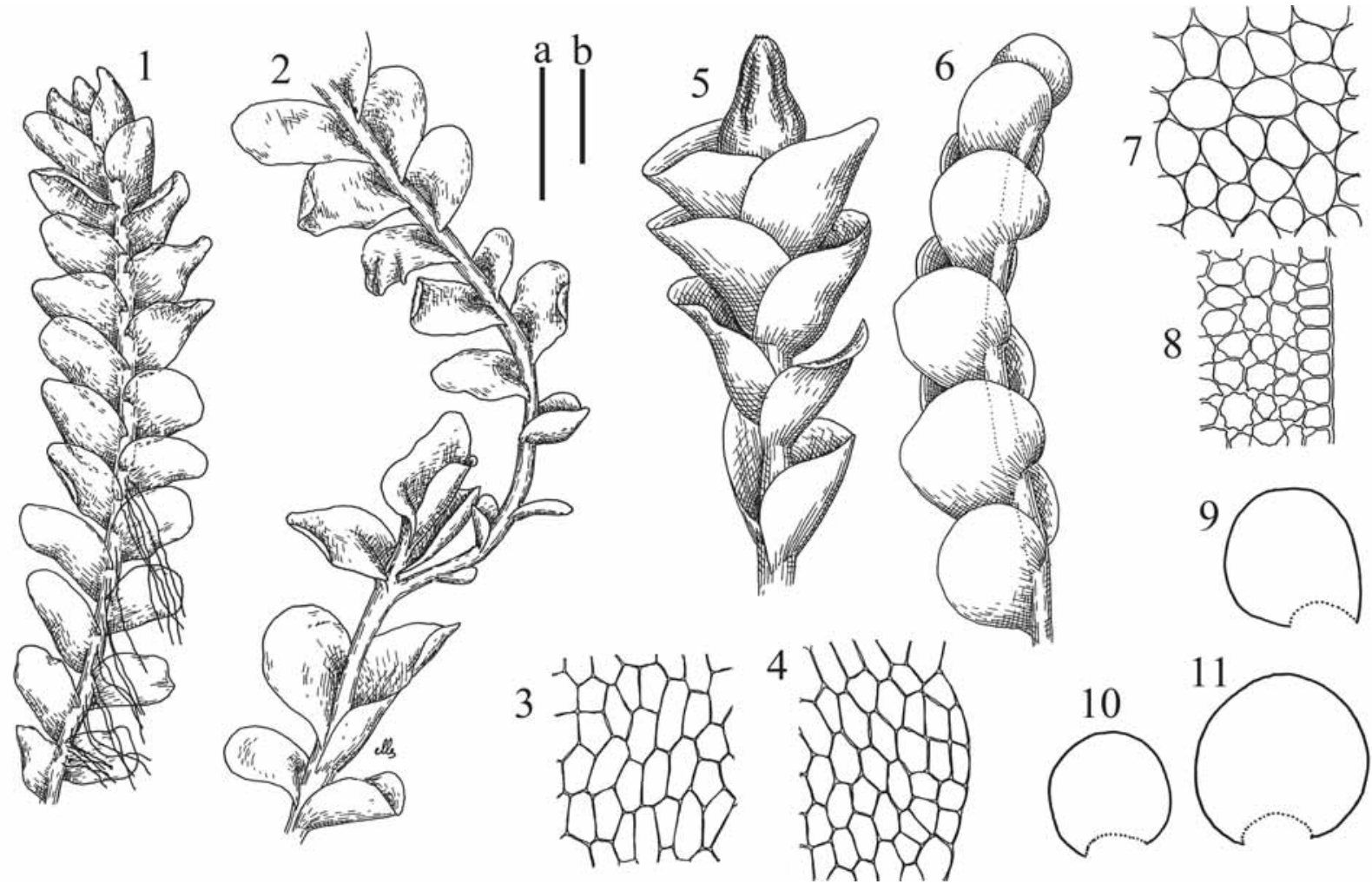

Fig. 23. Nardia verrucosa Steph., holotype (G14478/00115343): 1 - plant habit, ventral view; 2 - plant habit; 3 - midleaf cells; 4 - cells along leaf margin; Nardia vulcanicola Schiffn., holotype (G00121010): 5 - perianthous plant; 6 - plant habit - lateral view; 7 - midleaf cells; 8 - cells along leaf margin; 9-11 - leaves. Scales: a - $1 \mathrm{~mm}$, for 1, 2, 5, 6, 9-11; b - $100 \mu \mathrm{m}$, for 3, 4, 7, 8.

patches, soft. Stem $125-150 \mu \mathrm{m}$ in diameter, sparsely laterally branched, as well as lateral subfloral innovations (1 per perianth). Rhizoids brownish-purplish, originated from ventral side of stem (mostly concentrated near ventral leaf base), separated, obliquely spreading or decurrent down the stem, but not forming clear fascicle. Leaves horizontally spreading, very obliquely inserted, not or shortly decurrent dorsally, subtransversely to loosely arcuately inserted ventrally, where not or barely decurrent, flattened to slightly convex, contiguous or (rarely) distant, obliquely lingulate, $900-1100 \times 500-600 \mu \mathrm{m}$. Midleaf cells mostly oblong, 37.5-71.0×25.0-31.5 $\mu \mathrm{m}$, very thin-walled, trigones vestigial, concave, cuticle distinctly papillose-verrucose; cells along leaf margin 26.0 $38.5 \mu \mathrm{m}$, thin-walled, external wall very slightly thickened, trigones small, concave, cuticle distinctly papillose verrucose. Dioicous. Only unfertilized archegonia (with mature subfloral innovations before them) were found. (Fig. 23: 1-4).

Comment. Váňa (1974b) regards Nardia verrucosa as fully identical with Jungermannia dusenii (Steph.) Steph. (= Plectocolea dusenii (Steph.) Bakalin) with the exception of clearly verrucose cuticle. In the present study I found cuticle clearly verrucose in the type of Nardia dusenii Steph., too. The only difference I found is rhizoid coloration, which is deeper in Plectocolea dusenii.

59) Nardia vulcanicola Schiffn., Denkschr. Akad. Wiss. Wien, KI. Math.-Naturw. 67: 191. 1899.
Holotypus: Java. Prov. Praenger, ad lacum vulcanum "Telega Bodas". Regio Nubium. 1660 m a.s.l. 15.II.1894 (482) G00121010.

Accepted name: Plectocolea vulcanicola (Schiffn.) Bakalin, Arctoa 23: 117. 2014.

Description. Plants pellucid, rather erect in dense patches, pale yellowish-brownish, pallid, $1.25-2.25 \mathrm{~mm}$ wide and $12-20 \mathrm{~mm}$ long, rather soft. Stem $150-300 \mu \mathrm{m}$ in diameter, not branched (even as subfloral innovations), yellowish-brownish to brownish. Rhizoids sparse, grayish to brownish, originated mostly near ventral leaf bases, but not only there, erect to obliquely spreading. Leaves obliquely to very obliquely inserted, dorsally decurrent for $1 /$ $3-2 / 3$ of stem width, ventrally transversely to arcuately inserted, shortly (up to $1 / 3$ of stem width) decurrent, contiguous to subimbricate, loosely laterally appressed to the stem or obliquely spreading, more or less flattened to slightly concave or concave-canaliculate near perianth (3-5 pairs below perianth), obliquely lingulate to reniform, commonly emarginated at apex, 1000-1300×1000-1550 $\mu \mathrm{m}$, leaf margin commonly more deeply colored (looks as rim). Midleaf cells subisodiametric to shortly oblong, 37.5$70.0 \times 37.5-62.5 \mu \mathrm{m}$, thin-walled, trigones moderate in size, slightly concave to slightly convex, cuticle smooth; cells along leaf margin $18.7-25.0 \mu \mathrm{m}$, walls thin to moderately unequally thickened, trigones moderate in size, triangle to slightly concave or convex, external wall thickened. Dioicous? Perianth conical, pluriplicate (mostly with 4 


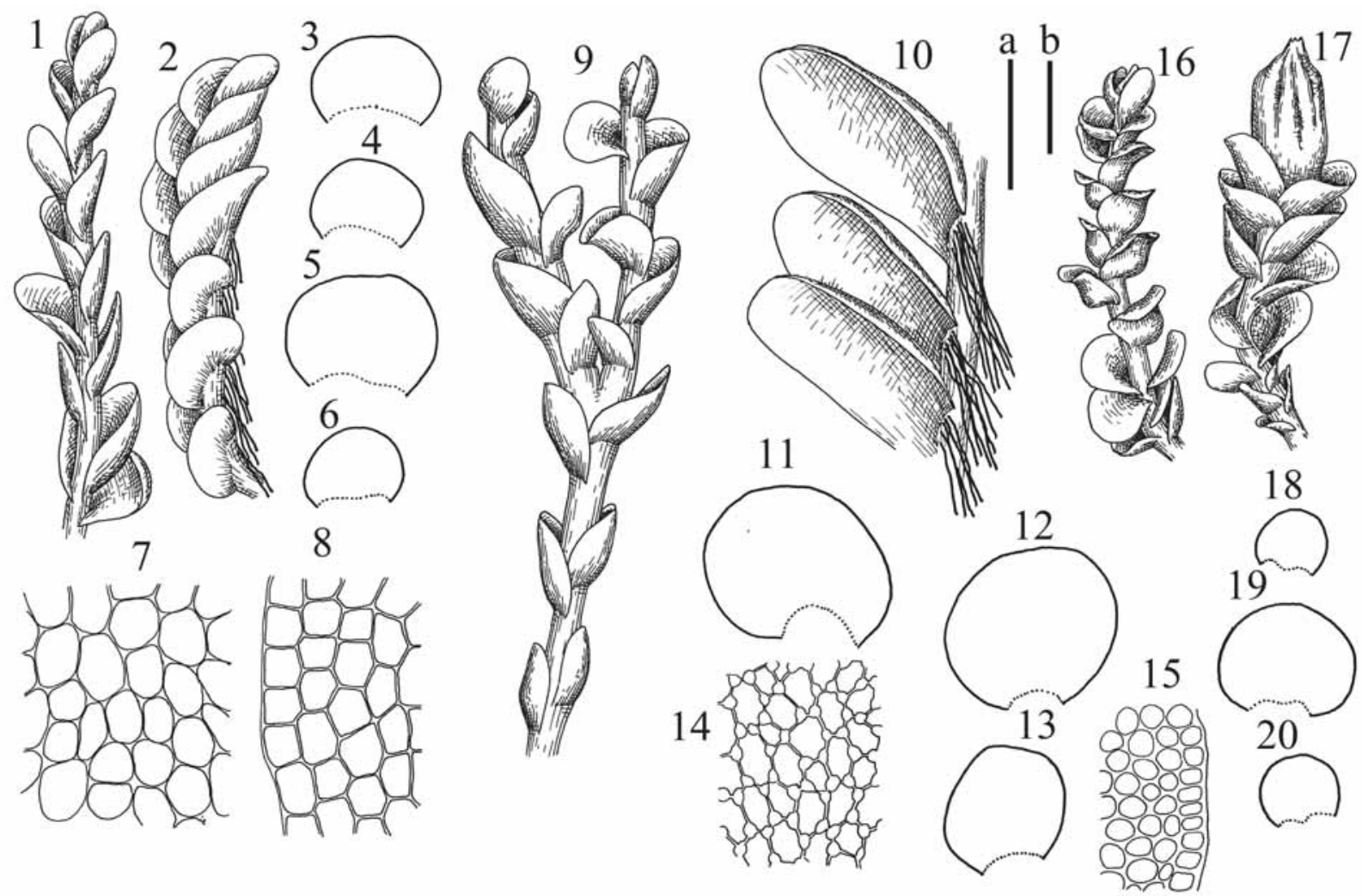

Fig. 24. Nardia vulcanicola Schiffn. var. tenuiretis Schiffn., syntype (G00120998): 1, 2 - plant habit; 3-6 - leaves; 7 - midleaf cells, 8 - cells along leaf margin; Nardia vulcanicola var. tenuiretis f. cavifolia Schiffn., holotype (G00120999): 9 - plant habit; Solenostoma radicellosum Mitt., isotype (G531/265243): 10 - ventral view of the plant, fragment; 11-13 - leaves; 14 - midleaf cells, 15 - cells along leaf margin; Solenostoma rostratum Steph., holotype (G11666/00112195): 16 - male plant; 17 - perianthous plant; $18-20$ - leaves. Scales: a $-1 \mathrm{~mm}$, for $1-6,9,11-13$; b - $100 \mu \mathrm{m}$, for 7, 8, 14, 15; a - $800 \mu \mathrm{m}$, for 16-20; a - 500 $\mu \mathrm{m}$, for 10 .

main plicae), gradually narrowed to the mouth, not turbinate in upper part, ca. $2000 \times 750 \mu \mathrm{m}$, composed by elongated pellucid cells; perigynium ca. 1/4 of perianth length, with 1 pair of bracts; bracts similar to large leaves but wider, undulate at margin and commonly slightly crispate. (Fig. 23: 5-11).

60) Nardia vulcanicola Schiffn. var. tenuiretis Schiffn., Denkschr. Akad. Wiss. Wien, KI. Math.-Naturw. 67: 191. 1899.

Syntypus: Prov. Praenger, ad lacum vulcanum "Telega Bodas". Regio Nubium. 1660 m a.s.1. 15.II.1894 (483) G00120998.

Accepted name: Plectocolea vulcanicola (Schiffn.) Bakalin var. tenuiretis (Schiffn.) Bakalin comb. nov. Basionym: Nardia vulcanicola Schiffn. var. tenuiretis Schiffn., Denkschr. Akad. Wiss. Wien, KI. Math.-Naturw. 67: 191. 1899.

Description. Plants prostrate, pale yellowish-brownish, forming loose mats, $0.6-1.25 \mathrm{~mm}$ wide and 10-15 $\mathrm{mm}$ long, more or less soft. Stem 200-250 $\mu \mathrm{m}$, not branched, pale yellowish-brownish. Rhizoids numerous, colorless to grayish, erect spreading, forming loose mat in ventral side of stem, originated mostly near ventral leaf base, but not only there. Leaves very to moderately obliquely inserted, ventrally decurrent for 1/4-3/4 of stem width, dorsally subtransversely to arcuately inserted, not or barely decurrent, reniform to transversely elliptic, truncate to shallowly emarginate at apex, 550-850×950-1400 $\mu \mathrm{m}$, contiguous, rarely distant, mostly slightly laterally appressed to the stem or obliquely spreading, slightly concave to almost flat. Midleaf cells subquadrate to rectangular and oblong, 37.5-62.5×25.0-45.0 $\mu \mathrm{m}$, thinwalled, trigones small to very small, concave, cuticle smooth; cells along leaf margin 25.0-42.0 $\mu \mathrm{m}$, thinwalled, with moderate in size, triangle to slightly concave or convex trigones, external wall noticeable thickened, cuticle smooth. (Fig. 24: 1-8).

Comment. Plants represent a lax form of Plectocolea vulcanicola with leaf margin cells larger than in the type variety.

61) Nardia vulcanicola var. tenuiretis f. cavifolia Schiffn., Denkschr. Akad. Wiss. Wien, KI. Math.-Naturw. 67: 192. 1899.

Holotypus: In monte ignivomo Papandian, ad fontes calidos in cratere. 14.II.1894. V. Schiffner (495) G00120999.

Accepted name: ?Plectocolea vulcanicola (Schiffn.) Bakalin var. tenuiretis (Schiffn.) Bakalin f. cavifolia (Schiffn.) Bakalin comb. nov. Basionym: Nardia vulcanicola Schiffn. var. tenuiretis Schiffn. f. cavifolia Schiffn., 

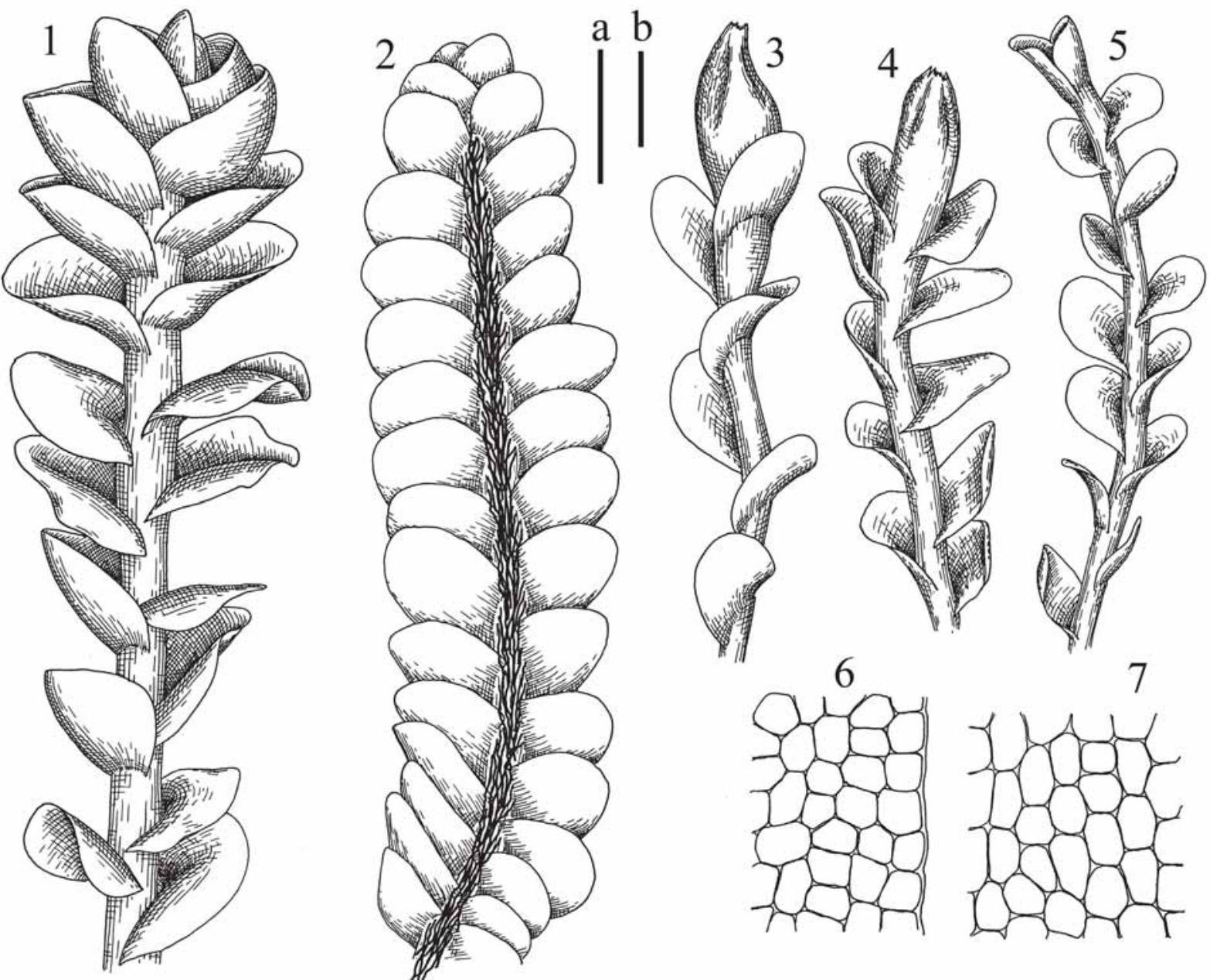

6

7
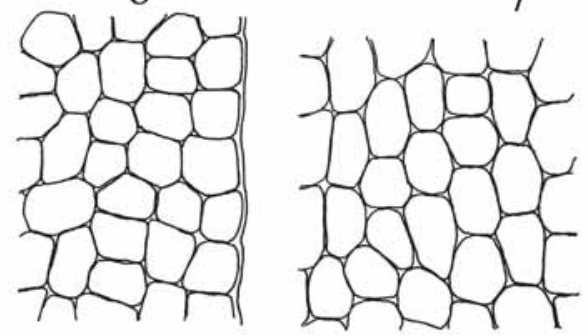

Fig. 25. Solenostoma radicellosum Mitt., isotype (G531/265243): 1 - plant habit; 2 - plant habit, ventral view; Solenostoma aomorense Steph., holotype (G00112198): 3, 4-perianthous plants, 5 - plant habit; 6 - cells along leaf margin; 7 - midleaf cells. Scales: $\mathrm{a}-1 \mathrm{~mm}$, for $1-5 ; \mathrm{b}-100 \mu \mathrm{m}$, for 6,7 .

Denkschr. Akad. Wiss. Wien, KI. Math.-Naturw. 67: 192. 1899.

Comment. By habit the plant are similar to Solenostoma fusiforme (Steph.) R. M. Schust. due to concave leaves sheathing the stem. Unfortunately, no perianths were found to check this suggestion (Fig. 24: 9).

62) Solenostoma aomorense Steph., Sp. Hepat. 6: 79. 1917.

Holotypus: Japan. Aomori. 1902. U. Faurie (1260) $\mathrm{G} / 00112198$.

Accepted name: Solenostoma fusiforme (Steph.) R. M. Schust., Hepat. Anth. North Amer. 2: 944. 1969.

Description. Plants pallid, yellowish-greenish to greenish-brownish, prostrate to loosely ascending, forming loose mat, $0.7-2.0 \mu \mathrm{m}$ wide, $5-10 \mathrm{~mm}$ long, purplish pigmentation present, but limited to perigynium and adjacent areas. Stem $175-250 \mu \mathrm{m}$ in diameter, yellowish-brownish, not branched. Rhizoids colorless to grayish and brownish, originated from ventral side of stem, perigynium and lower $1 / 4$ of perianth, obliquely spreading, to sometimes forming loose mat in ventral side of stem or decurrent down, but not forming the fas- cicle. Leaves obliquely inserted, rather distant, obliquely spreading, loosely concave, dorsally not or barely decurrent, ventrally subtransversely to arcuately inserted, not or barely decurrent, nearly suborbicular to reniform, 550$875 \times 700-1150 \mu \mathrm{m}$. Midleaf cells subisodiametric to oblong, $27.5-52.5 \times 26.0-42.5 \mu \mathrm{m}$, thin-walled, trigones small, concave, cuticle virtually smooth. Dioicous? Perianth fusiform, slightly 3-plicate in upper $1 / 3-1 / 2$ of its length, gradually narrowed to the not beaked mouth, $1600-2100 \times 750-800 \mu \mathrm{m}$, exerted for $4 / 5$ of its length, bistratose in lower $1 / 4$, composed by rectangular to elongate cells, at middle part 56.0-90.0×33.5-44.0 $\mu \mathrm{m}$, thinwalled, with small, concave trigones; perigynium ca. $1 / 4$ of perianth length, with 1 pair of bracts, commonly purple or pale violet colored; female bracts similar to large leaves, rarely emarginated at the apex, loosely sheathing the perianth in lower $1 / 3$ and obliquely spreading above. (Fig. 25: 3-7).

Comment. Amakawa (1960) synonymyzed Solenostoma aomorense Steph. with Jungermannia fusiformis (Steph.) Steph. (= Solenostoma fusiforme (Steph.) R.M. Schust.). Due to the presence of purplish pigmentation 
and the presence of short perigynium it is rather identical with the type of Solenostoma koreanum Steph., regarded here as a modification of S. fusiforme as well, but treated as separate species in Amakawa (1.c.).

63) Solenostoma appalachianum R.M. Schust. ex Bakalin sp. nov.

Holotypus: U.S.A. North Carolina, Jackson Co. 1.IX.1953 R.M. Schuster (No. 29379) G 25914/ 00067159

Accepted name: Solenostoma appalachianum R.M. Schust. ex Bakalin.

Description. Plants yellowish-green to yellowish-light green, ascending in loose patches, with markedly purple pigmented perianth tip, $1.5-2.25 \mathrm{~mm}$ wide and 3-5 mm long, no purplish pigmentation in other areas. Stem 200 $300 \mu \mathrm{m}$ in diameter, not branched, pale greenish to pale yellowish-greenish, not or slightly flexuous. Rhizoids colorless to brownish, sparse to numerous, erect to obliquely spreading or decurrent down the stem, but not forming the fascicle. Leaves subtransversely (ca. $70-80^{\circ}$ with axis) inserted, concave to concave-canaliculate, mostly erect spreading, dorsally decurrent for $1 / 3-1 / 2$ of stem width, ventrally transversely to obscurely arcuately inserted, not or shortly (up to $1 / 3$ of stem width) decurrent, 750$900 \times 900-1150 \mu \mathrm{m}$, suborbicular to transversely elliptic, contiguous to subimbricate and enclosed one to another. Midleaf cells subisodiametric to shortly oblong, 25.0$37.5 \times 18.5-27.5 \mu \mathrm{m}$, thin-walled, trigones moderate, triangle to slightly convex, cuticle virtually smooth; cells along leaf margin 15.0-22.5 $\mu \mathrm{m}$, thin-walled, with thickened external wall, trigones moderate, convex, cuticle smooth. Dioicous? Perianth 1000-1300×600-800 $\mu \mathrm{m}, 3-$ 4-plicate in upper half, gradually narrowed to indistinctly beaked mouth, upper part of perianth markedly purple colored, mouth crenulate, perianth composed by subisodiametric cells. (Fig. 26: 1-8).

Comment. Solenostoma appalachiana has never been validly published by Schuster, and later he referred this specimen to S. pyriflorum Steph. (Schuster, 1969). The plants in the described specimens agreed well with the $S$. pyriflorum type, with the exception of much larger size and slightly larger leaf cells, and also with the exception of purple colored perianth tip (in the absence of purple coloration in other parts of the shoot). The mentioned features, as well as strong geographic isolation between Japan and Eastern North America allow to treat S. appalachianum at the species level.

64) Solenostoma atrovirens Steph., Sp. Hepat. 2: 55. 1901.

Holotypus: Reunion 25.V.1875. G. de l'Isle (201) G14313/00045603.

Accepted name: Solenostoma atrovirens Steph., Sp. Hepat. 2: 55. 1901.

Description. Plants rather erect, brownish-green to greenish-brownish, no red pigmentation, ca. 1.5-2.0 mm wide and 10-20 mm long. Stem 200-250 $\mu \mathrm{m}$ in diameter, flexuous in sterile shoots, not branched. Rhizoids of two types: 1) decurrent down the stem and forming fascicle, brownish in color, 2) erect spreading and forming mat under stem, purple-brown, rarely purplish in color. Leaves subtransversely inserted, obliquely to erect spreading, concave-canaliculate, sometimes with recurved apex, dorsally decurrent for $1 / 2-3 / 4$ of stem width, distant to contiguous (most commonly latter) and subimbricate, commonly (especially larger ones) undulate at margin, suborbicular to transversely elliptic, $750-1000 \times 900-1400$ $\mu \mathrm{m}$. Midleaf cells oblong, 25.0-31.5×12.5-20.0 $\mu \mathrm{m}$, thinwalled, trigones moderate, concave, cuticle smooth. Dioicous. Perianth clavate, 3(4)-plicate in upper $1 / 5$, suddenly contracted to the beaked mouth, exerted for $3 / 4$ of its length, bistratose in lower half, cells in upper part of perianth subisodiametric, thin-walled, trigones moderate in size, concave to slightly convex, cells in lower part of perianth (lower third) elongate, 31.0-42.0×10.0-18.0 $\mu \mathrm{m}$, with thickened walls, trigones moderate in size to small, concave; perigynium virtually absent; female bracts similar to leaves, but wider, undulate at margin and loosely sheathing the perianth. (Fig. 26: 9-15).

Comments. a) The species has been synonymyzed by Váňa (1973, 1974b) with Jungermannia perloi (Gola) Váňa (= Solenostoma perloi Gola Memor. Reale Accad. Sci. Torino, ser. 2 65: 4. 1914.), described from Kenia (Gola, 1914). At that time Váňa (1974b) regarded Jungermannia in a broad sense (as including Solenostoma and Plectocolea) and used for the species the name Jungermannia perloi (Gola) Váňa because although Solenostoma atrovirens had been described 13 years before than $S$. perloi, a combination "Jundermannia atrovirens" was blocked by the presence of the earlier homonym Jungermannia atrovirens Dumort. Here Solenostoma is treated as a genus clearly separate from Jungermannia and it is possible to use the earliest name Solenostoma atrovirens.

b) I have not studied the type of Solenostoma perloi, probably the statement on their identity needs further consideration.

65) Solenostoma australe Steph., Sp. Hepat. 6: 79. 1917.

Holotypus: N-E. Australia. Bellender Ker Montes. Karsten G14314/00067144.

Accepted name: Plectocolea montana (Steph.) Bakalin, Arctoa 23: 102. 2014.

Description. Plants prostrate, greenish-brownish to brownish-greenish, in loose patches, 1.25-2.0 $\mu \mathrm{m}$ wide, 5-7 mm long. Stem 125-200 $\mu \mathrm{m}$ in diameter, wider near perianth, sparsely branched as ventral geotropic scaleleaved 'stolons', rarely as lateral subfloral innovations. Rhizoids sparse or sometimes numerous, originated from ventral side of stem, obliquely to erect spreading, or decurrent down the stem, but not forming distinct fascicle, purple, purple-brown and (rarer) brownish in color. Leaves obliquely inserted, not decurrent dorsally, subtransversely 

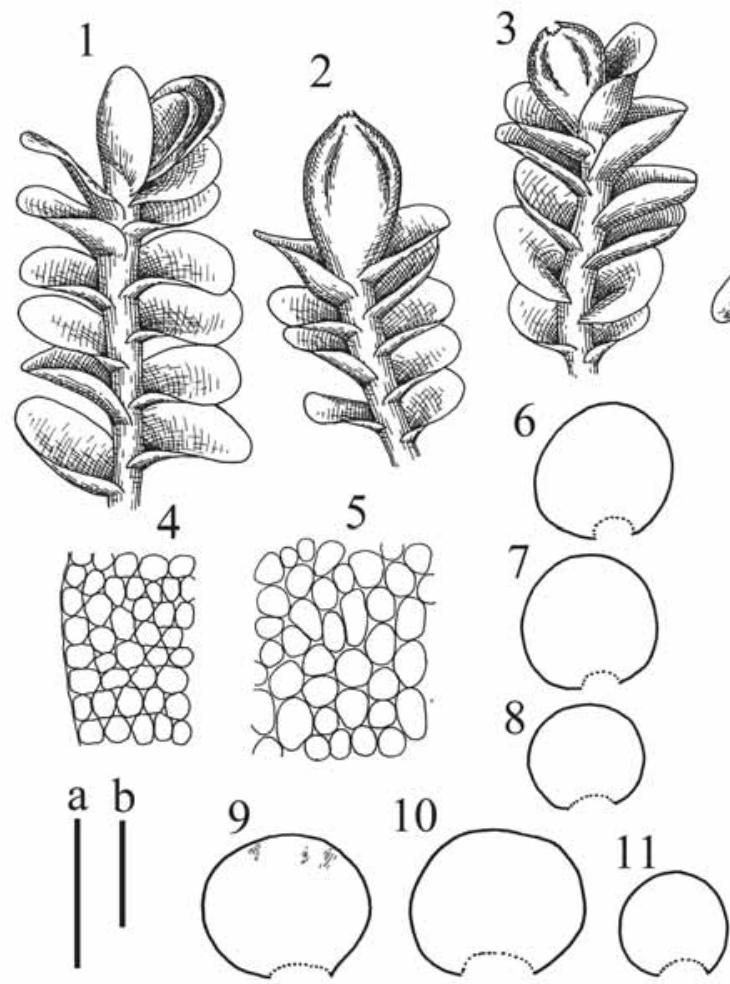
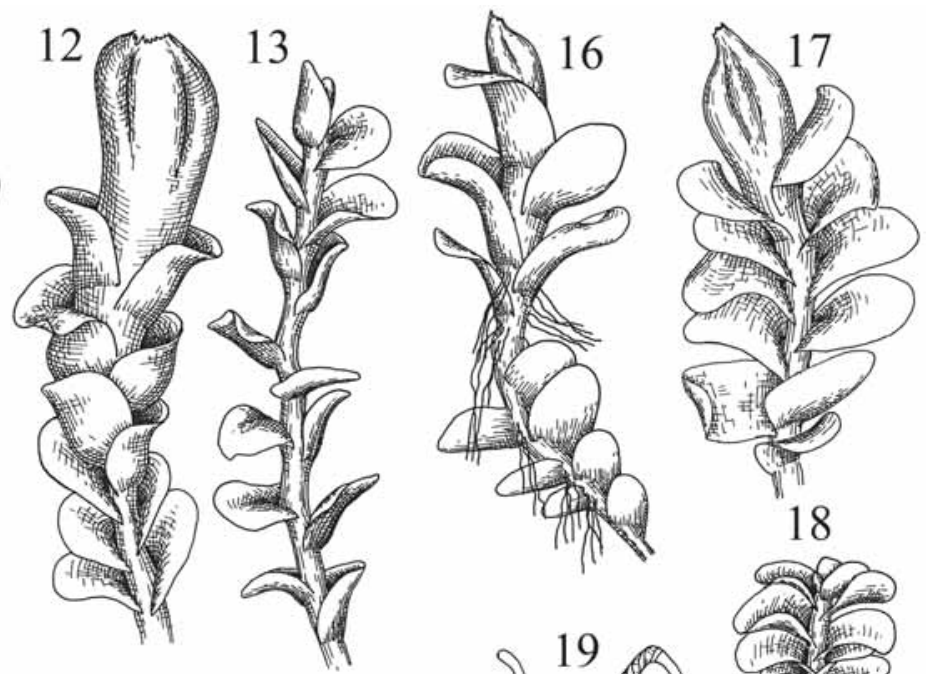

18

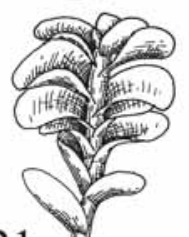

14

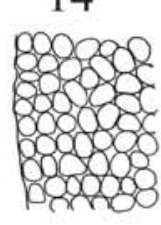

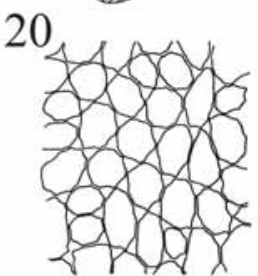

Fig. 26. Solenostoma appalachianum R.M. Schust. ex Bakalin, holotype (G25914/00067159): 1 - plant habit; 2, 3 - perianthous plants, 4 - cells alng leaf margin, 5 - midleaf cells, 6-8 - leaves; Solenostoma atrovirens Steph., holotype (G14313/00045603): 9-11 - leaves, 12 - perianthous plant; 13 - plant habit; 14 - cells along leaf margin; 15 - midleaf cells; Solenostoma australe Steph., holotype (G14314/00067144): 16 - perianthous plant - ventral view; 17, 18 - perianthous plants; 19 - elater; 20 - midleaf cells; 21 - cells along leaf margin. Scales: $\mathrm{a}-1 \mathrm{~mm}$, for $1-3,6-13,16-18 ; \mathrm{b}-100 \mu \mathrm{m}$, for 4, 5, 14, 15, 20, $21 ; \mathrm{b}-50 \mu \mathrm{m}$, for 19 .

to loosely arcuately inserted ventrally, where not decurrent, loosely sheathing the stem near base and obliquely to erect spreading above, in general outline slightly convex, but sheathing stem near base, mostly contiguous, ovate to obliquely ovate, $750-1600 \times 500-1350 \mu \mathrm{m}$. Midleaf cells subisodiametric to shortly oblong, 33.5-43.0×27.5-37.5 $\mu \mathrm{m}$, thin-walled, trigones moderate in size, convex, cuticle virtually smooth; cells along leaf margin 18.5-32.5 $\mu \mathrm{m}$, thin-walled to slightly thickened, trigones moderate, convex, external wall thickened. Dioicous? Perianth fusiform to subclavate, with 3 main plicae in upper half, gradually narrowed to the mouth, composed by elongated cells, ca. $1400-1500 \times 600-750 \mu \mathrm{m}$, exerted for $3 / 4$ of its length, bistratose in lower $1 / 3$; perigynium distinct, ca. $1 / 3-2 / 5$ of perianth length, with two pairs of bracts; female bracts similar to large leaves, but wider, sheathing perianth near base and erect spreading above. Spores papillose, 18.5$22.0 \mu \mathrm{m}$ in diameter, brown. Elaters bispiral, ca. $100 \times 7.5$ $\mu \mathrm{m}$, with homogenous ends ca. 15-20 $\mu \mathrm{m}$ long. (Fig. 26: 16-21).

Comments. a) Váňa added the notice to the herbarium sheet (G14314/00067144) "=Jungermannia karsteniana Beauverd". The latter species was described as Nardia montana Steph., but due to an earlier homonym (Jungermannia montana Mart. Fl. Crypt. Erlangensis 155. 1817) was substituted by this new name. The description of Solenostoma australe is based on the same(!) specimen, which was also stressed by Ván̆a (1975a).

b) Both Nardia montana Steph. and Solenostoma australe Steph. were regarded as synonymous with Jungermannia wattsiana Steph. by Ván̆a (1975a), with whom I fully agree. The types of J. hirticalyx Steph., J. wattsiana Steph. and Solenostoma australe Steph./Nardia montana Steph. represent one species, and its name should be Plectocolea montana due to priority principle.

66) Solenostoma cinerea Mitt. in Steph., Sp. Hepat. 2: 49. 1901 .

Lectotypus (selected by Amakawa 1969): Java. In monte Pangerango Motley G12928/115353.

Accepted name: ?Solenostoma strictum (Schiffn.) Váňa, Hentschel \& J. Heinrichs, Crypt. Bryol. 31(2): 138. 2010.

Description. Plants ascending to erect, in loose patches (mixed with Riccardia), 1.0-1.25 mm wide (in perianthous plants up $2.75 \mathrm{~mm}$ wide), 8-13 mm long, yellowish-brownish, with purplish tint to brownish-purple in perianth base and adjacent area. Rhizoids numerous, originated from ventral side of stem, forming distinct fascicle decurrent along the stem (similar in diameter to stem), brownish. Leaves concave, obliquely spreading, distant to contiguous, transversely inserted, dorsally decurrent for ca 1.0 of stem width, ventrally decurrent for ca. 1.0 1.5 of stem width, suborbicular to transversely elliptic, 


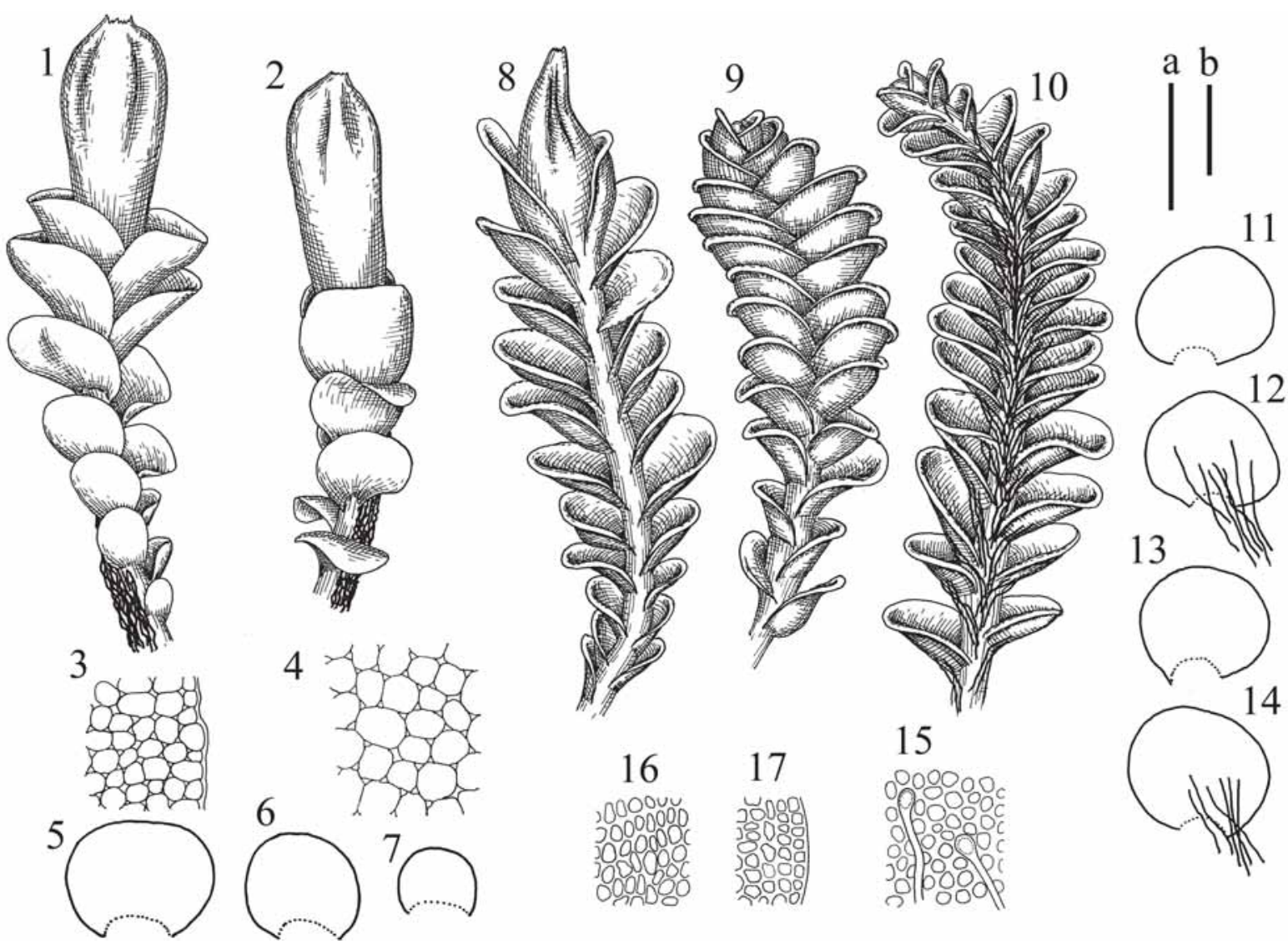

Fig. 27. Solenostoma cinereum Mitt., lectotype (G12928/115353): 1, 2 - perianthous plants; 3 - cells along leaf margin; 4 midleaf cells; 5-7 - leaves; Jungermannia flavorevoluta Váňa, isotype (G11168/00115180): 8 - perianthous plant; 9, 10 - plant habits; 11-14 - leaves; 15, 16 - midleaf cells; 17 - cells along leaf margin. Scales: a - $1 \mathrm{~mm}$, for 1, 2, 5-14; b - $100 \mu \mathrm{m}$, for 3, 4, $15-17$.

625-700×825-1375 $\mu \mathrm{m}$. Midleaf cells nearly isodiametric, $25-40 \times 25-40 \mu \mathrm{m}$, thin-walled, trigones moderate in size to large, convex, cuticle smooth; cells along leaf margin $12.5-19.0 \mu \mathrm{m}$, walls thin to unequally thickened, trigones large, convex, sometimes confluent, cuticle smooth. Dioicous. Androecia intercalary, with 2-3 pairs of bracts, inflated in lower half and concave above (data on androecia based on very bad material). Perianth 2500 $3000 \times 900-1000 \mu \mathrm{m}$, clavate, 4-5-plicate in upper 1/ $4(1 / 3)$, gradually narrowed to not beaked mouth, exerted for 4/5-6/7 of the length, perianth middle part composed by isodiametric to shortly oblong cells, thin-walled, with moderate in size, convex trigones, bistratose in lower half (where it composed by elongate cells); perigynium absent or up to $1 / 5$ of perianth length; female bracts similar to large leaves, obliquely spreading, concave-canaliculate. (Fig. 27: 1-7).

Comments. a) Solenostoma cinereum Mitt. in Steph. was synonymyzed with Jungermannia stricta (Schiffn.) Steph. (= Solenostoma strictum (Schiffn.) Váňa, Hentschel \& J. Heinrichs) by Ván̆a (1972b), although earlier Ván̆a had indicated in the label in G Jungermannia herzogiana Váňa. The plants of $S$. cinereum and $S$. strictum are strikingly different in color: purplish in $S$. cirenerum, while totally lacking this pigmentation in $S$. strictum. Other slight differences are in perianth size $1750 \times 750 \mu \mathrm{m}$ in $S$. strictum versus $2500-3000 \times 900-1000$ $\mu \mathrm{m}$ in $S$. cinereum. Whether these differences are sufficient to recognize these taxa at the species level is unclear for me.

b) In Mitten herbarium in NY there is no type material, thus Amakawa selected this specimen in $G$ as the lectotype.

67) Solenostoma gollanii Steph., Sp. Hepat. 6: 81. 1917.

Holotypus: India. Sikkim. 7000 ped. Hartless G12929/ 00043700.

Accepted name: Solenostoma purpuratum (Mitt.) Steph. var. gollanii (Steph.) Bakalin comb. nov. Basionym: Solenostoma gollanii Steph., Sp. Hepat. 6: 81. 1917; = Solenostoma purpuratum (Mitt.) Steph. var. koponenii Bakalin et Li Wei Arctoa 22: 135. 2013. syn. nov.

Description. Plants greenish-brownish, erect, among Riccardia, $0.75-1.0 \mathrm{~mm}$ wide and 5-15 $\mathrm{mm}$ long. Stem $175-250 \mu \mathrm{m}$ in diameter, not branched, brownish. Rhizoids numerous, forming distinct fascicle decurrent down the stem, fascicle the same size or wider than stem, colorless to brownish. Leaves subtransversely to transversely inserted, dorsally decurrent for 1-2 of stem widths, ven- 


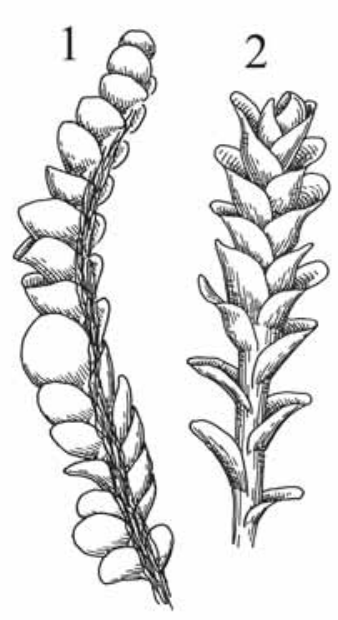

4

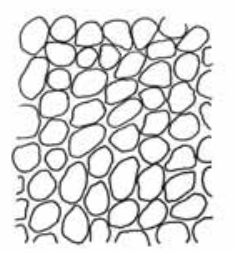

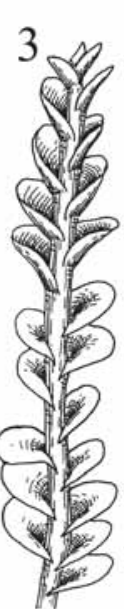

5

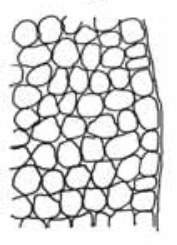

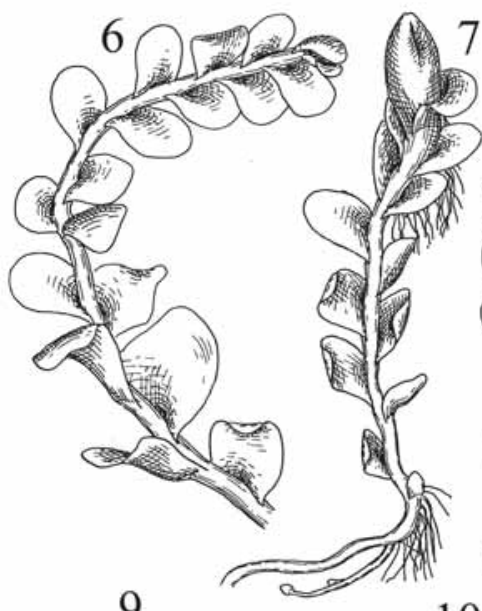

9

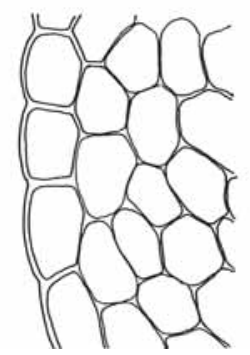

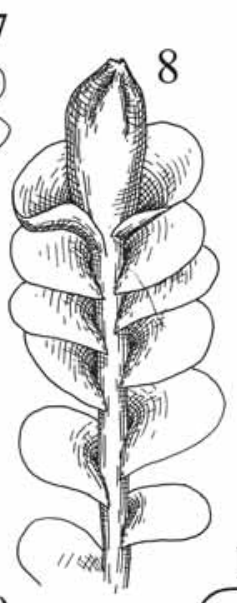

10

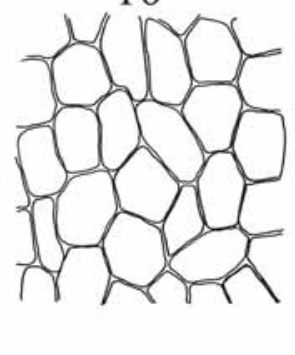

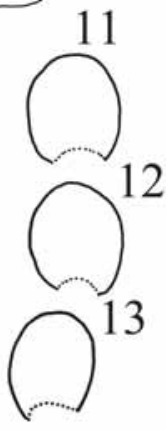

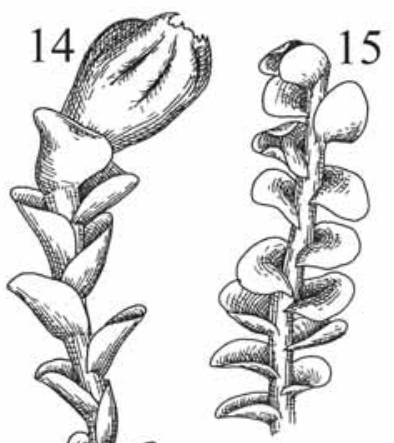

15
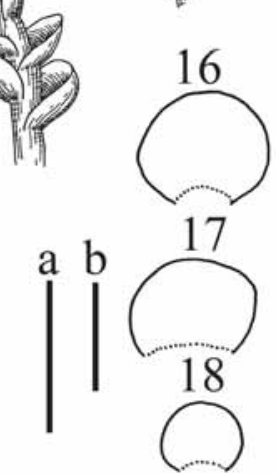

Fig. 28. Solenostoma gollanii Steph., holotype (G12929/00043700): 1 - plant habit, ventral view; 2, 3 - lant habit; 4 - midleaf cells; 5 - cells along leaf margin; Solenostoma koreanum Steph., holotype (G16635/00112199): 6 - plant habit; 7, 8 - perianthous plants; 9 - cells along leaf margin; 10 - midleaf cells; 11-13 - leaves; Solenostoma obtusiflorum Steph., holotype (G11677/00112187): 14 - perianthous plant; 15 - plant habit; $16-18$ - leaves. Scales: a - $1 \mathrm{~mm}$, for $1-3,6-8,11-18$; b - $100 \mu \mathrm{m}$, for 4, 5, 9, 10 .

trally decurrent for 3/4-5/4 of stem width, concave to concave-canaliculate, obliquely spreading, suborbicular, 600 $625 \times 750-775 \mu \mathrm{m}$. Midleaf cells subisodiametric to shortly oblong, 18.5-25.0×18.5-25.0 $\mu \mathrm{m}$, thin-walled, trigones moderate to large, convex, cuticle smooth; cells along leaf margin 12.5-19.0 $\mu \mathrm{m}$, thin-walled, trigones moderate to large, convex, sometimes confluent, cuticle smooth. Androecia spicate, intercalary, with 2-5 or more pairs of bracts, strongly inflated in lower half and recurved to erect spreading above. (Fig. 28: 1-5).

Comment. Solenostoma gollanii Steph. was synonymized with Jungermannia appressifolia Mitt. by Ván̆a (1972b). The plants in the type of Solenostoma gollanii differ from Solenostoma appressifolium (Mitt.) Váňa \& D.G. Long in (based on comparison with holotype in NY, 00944021 !) in: 1) size of shoots $(0.75-1.0 \mathrm{~mm}$ wide in $S$. gollanii, versus 1.32-1.76 mm wide in S. appressifolium); 2) color (greenish-brownish versus yellowish-brown, with rusty to red tint); 3) leaf position (obliquely spreading versus appressed to the stem). Recently described $S$. purpuratum var. koponenii Bakalin et Li Wei does not differ from the type of Solenostoma gollanii, thus it is synonymized with $S$. purpuratum var. gollanii

68) Solenostoma koreanum Steph., Sp. Hepat. 6: 81. 1917.

Holotypus: Korea. Quelpart (Jeju Island) 1906 U. Faurie (No. 236) G16635/00112199.
Accepted name: ?Solenostoma fusiforme (Steph.) R. M. Schust., Hepat. Anth. North Amer. 2: 944. 1969.

Description. Plants prostrate, loosely ascending near the perianth, pellucid, pallid, pale yellowish-greenish to greenish-brownish, area near base of perianth, perigynium and adjacent parts of leaves and stem purplish colored, $1.0-1.5 \mathrm{~mm}$ wide (hardly wider in large perianthous plants), forming loose patches, more or less closely attached to the substratum by rhizoids, dorsiventrally flattened. Stem $100-150 \mu \mathrm{m}$ in diameter, slightly wider near the perianth, flexuous, especially in smaller plants, not branched, or with stolon-like ventral leafless branches, that sometimes become to normal branches. Rhizoids sparse, purple to colorless, originated from ventral side of stem, distributed not evenly, but in some areas of ventral side (commonly where stem curving). Leaves very obliquely inserted, horizontally spreading, distant to contiguous, dorsally shortly or up to $1 / 2$ of stem width decurrent, ventrally obliquely to subtransversely, rarely arcuately inserted, not or barely decurrent, more or less flattened to loosely concave-canaliculate, obliquely ovate to obliquely lingulate, $550-725 \times 575-875 \mu \mathrm{m}$. Midleaf cells mostly penta- to hexagonal, oblong, 50.0-750×37.5$50.0 \mu \mathrm{m}$, thin-walled, trigones small to vestigial, concave, cuticle smooth; cells along leaf margin 50.0-62.5 $\mu \mathrm{m}$, subequally thickened, trigones small, concave, cuticle virtually smooth. Dioicous? Perianth 3(4)-plicate in 

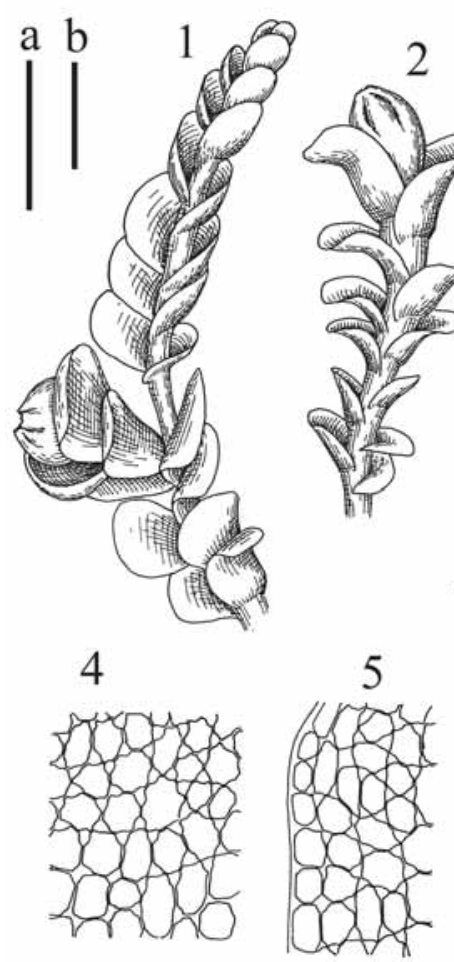
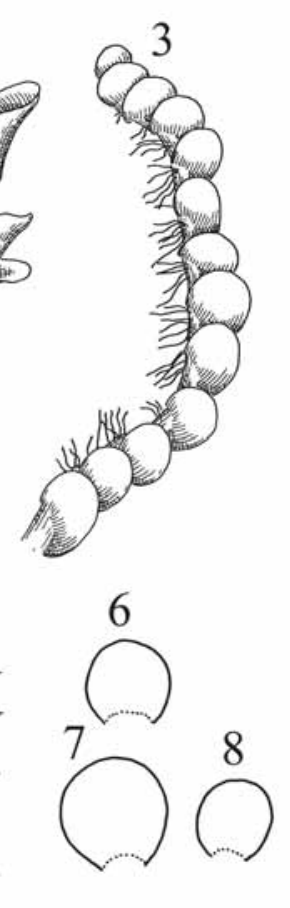
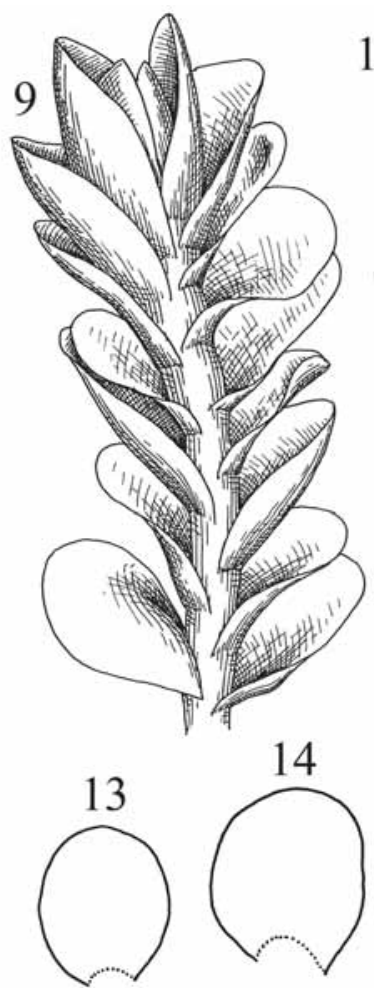

11

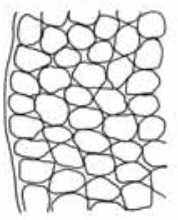

12

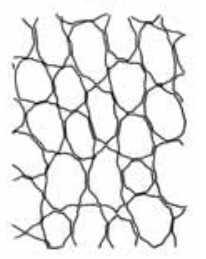

Fig. 29. Solenostoma lacouturei Steph., holotype (G14318/00045606): 1, 2 - perianthous plants; 3 - plant habit, lateral view; 4 - midleaf cells; 5 - cells along leaf margin; 6-8 - leaves; Solenostoma ovicalyx Steph., holotype (G16636/00067157): 9 - plant habit; 10 - male plant; 11 - cells along leaf margin; 12 - midleaf cells; 13-16 - leaves. Scales: a - $1 \mathrm{~mm}$, for 1-3, 6-10, 13-16; $\mathrm{b}-100 \mu \mathrm{m}$, for $4,5,11,12$.

almost whole extent or almost free of plicae, fusiform to clavate, mostly gradually narrowed to distinctly or indistinctly beaked mouth, $1250-1500 \times 400-650 \mu \mathrm{m}$, exerted for $2 / 3-3 / 4$ of its length, composed by elongated cells, virtually unistratose; perigynium present, ca. $1 / 5-1 / 4$ of perianth length, with 1 pair of bracts; female bracts similar to leaves, sheathing the perianth near base (in lower half) and obliquely spreading above, where canaliculate. (Fig. 28: 6-13).

Comment. Solenostoma koreanum Steph. was synonymyzed with Jungermannia fusiformis (Steph.) Steph. (= Solenostoma fusiforme (Steph.) R.M. Schust.) by Váňa (1975c) and H. Inoue (1975). This is contrasting to Amakawa (1960) who believed two names correspond to different species. Common phases(?) of "Solenotoma koreanum" differ from a typical $S$. fusiforme in presence of purplish pigmentation in some parts of shoot and commonly purplish rhizoids. Whether these distinctions merit a species level is the question of further study. Currently I accept (with some doubts) the concept of synonymy of both epithets, with $S$. fusiforme as a priority name. 1917.

69) Solenostoma lacouturei Steph., Sp. Hepat. 6: 81.

Holotypus: Madagascar. 1907 Camboue G14318/ 00045606.

Accepted name: Solenostoma lacouturei Steph., Sp. Hepat. 6: 81. 1917.
Description. Plants ascending to erect, in dense to loose patches, yellowish-brownish, $0.75-1.5 \mathrm{~mm}$ wide and 5-8 $\mathrm{mm}$ long, more or less rigid. Stem 100-250 $\mu \mathrm{m}$ in diameter, wider near the perianth, not branched, with the exception of lateral subfloral innovations (1 per perianth, rarely 1 ventral and 1-lateral), that becoming into normal branch, but remain sterile. Rhizoids sparse, brownish to colorless, originated mostly near ventral leaf base, but not only there, obliquely to erect spreading, separated. Leaves concave (small sterile branches) to concave-canaliculate (bigger, mostly fertile branches), contiguous to subimbricate, obliquely spreading or loosely laterally appressed to the stem and overlapping one to another, suborbicular to transversely elliptic, 550-800×550-960 $\mu \mathrm{m}$, obliquely inserted (subtransversely to transversely near the perianth), dorsally not or barely decurrent, ventrally subtransversely to arcuately inserted, not or barely decurrent. Midleaf cells isodiametric to oblong, $25.0-50.0 \times 25.0-37.5 \mu \mathrm{m}$, slightly thickwalled, trigones moderate in size, convex, sometimes bulging, cuticle distinctly papillose; cells along leaf margin $22.5-37.5 \mu \mathrm{m}$, thin- to slightly thick-walled, external wall thickened, cuticle virtually smooth, trigones moderate in size, convex to bulging. Dioicous? Perianth clavate, 850 $1100 \times 500-850 \mu \mathrm{m}, 4(5)$-plicate in upper $1 / 3$, suddenly contracted to the not beaked mouth, exerted for $1 / 2-2 / 3$ of the length, composed by subisodiametric cells, slightly rhizogenous and bistratose in lower $1 / 3$, perigynium virtually absent. (Fig. 29: 1-8). 
Comment. Solenostoma lacouturei Steph. was synonymyzed with Jungermannia borgenii Gott. (= Solenostoma stoloniferum (Steph.) S.W. Arnell) by Váňa (1974b). In contrast, I found two taxa different in size of shoots $(0.75-1.5 \mathrm{~mm}$ wide in $S$. lacoturei versus 1.5-2.0 $\mathrm{mm}$ wide in $S$. borgenii), midleaf cells measurements (25.0-37.5 $\mu \mathrm{m}$ wide versus $15.0-19.0 \mu \mathrm{m}$ wide), size of perianthium $(850-1100 \times 500-850 \mu \mathrm{m}$ versus 1500 $2000 \times 1000-1500 \mu \mathrm{m})$. For this reason I cannot follow Váňa (1974b) arguments and prefer to treat $S$. lacouturei as a species separate from $S$. stoloniferum.

70) Solenostoma obtusiflorum Steph., Kungl. Svensk. Vetensk. Handl. 46(9): 161911.

Holotypus: Juan Fernandez. Masafuera. 1908. Skottsberg (No. 105) G11677/00112187.

Accepted name: Solenostoma crassulum (Nees et Mont.) Steph., Sp. Hepat. 2: 59. 1901.

Description. Plants soft, prostrate to ascending, in loose patches, $0.5-1.2 \mathrm{~mm}$ wide and 3-7 mm long, yellowish-greenish to greenish-brownish, marked with red or purple in the branch base and perianth tips, dorsiventrally flattened. Stem $125-200 \mu \mathrm{m}$ in diameter, not branched, even as subfloral innovations, brownish to brownish-yellowish. Rhizoids sparse, colorless to grayish, erect spreading and not forming fascicles. Leaves obliquely inserted, not or rarely (rarely up to $1 / 4$ of stem width) decurrent dorsally, arcuately inserted, not or barely decurrent ventrally, loosely concave (sterile branches) to concave-canaliculate (fertile branches), contiguous to distant, orbicular to reniform and transversely elliptic, sometimes undulate and loosely crispate at margin, 450$750 \times 400-1050 \mu \mathrm{m}$. Midleaf cells subisodiametric to shortly oblong, 18.5-29.0(35.0)x18,5-27.5 $\mu \mathrm{m}$, thinwalled, trigones moderate, triangle to slightly concave or convex, cuticle virtually smooth; cells along leaf margin $12.5-24.0 \mu \mathrm{m}$, thin-walled, external wall not thickened, trigones moderate in size, concave, cuticle smooth. Dioicous? Perianth rhizogenous in lower $1 / 4-1 / 3$ if the length, obovate, $1250-1500 \times 800-1200 \mu \mathrm{m}$, with $4-5$ main plicae in upper half, gradually or more or less suddenly contracted to the not beaked mouth, exerted for $3 /$ 4-4/4 of its length; perigynium virtually absent; female bracts similar to large leaves, obliquely spreading, concave-canaliculate to concave. (Fig. 28: 14-18).

Comments. a)Váňa (1974a, p. 191) synonymized "Solenostoma obtusiflos Steph. K. Svenska-Vet. Akad. Hndl. 46(9): 16, 1911" with Jungermannia crassula Nees et Mont. (=Solenostoma crassulum (Nees et Mont.) Steph.). Váňa refers to page 16 in paper of Stephani (1911), where only three species of Solenostoma are listed: "S. crassulum Mont.", "S. obtusiflorum n. sp." and "S. rostratum n. sp.". Thus it is rather obvious that "obtusiflos" is a misprinting of $S$. obtusiflorum.

b) In comparison with the description of Jungermannia crassula Nees et Mont. provided by Váňa (1974a) plants in the type of $S$. obtusiflorum differ in leaf cell size. However, since I have not studied the type of Jungermannia crassula, I tentatively accept Váňa’s (1.c.) decision.

71) Solenostoma ovicalyx Steph., Sp. Hepat. 6: 82. 1917.

Holotypus: Japan. Mt. Komagadake. VIII.1903. K. Tamura (37) G16636/00067157.

Accepted name: Plectocolea infusca Mitt., Trans. Linn. Soc. London, Botany 3(3): 196. 1891.

Description. Plants prostrate to ascending, $1.75-3.0 \mathrm{~mm}$ wide and 10-15 mm long, in loose patches, yellowish-brownish. Stem $200-450 \mu \mathrm{m}$ in diameter, not branched, with the exception of lateral subfloral innovations that becoming into normal branch and easily fertilized again. Rhizoids numerous, brownish, obliquely spreading in unclear fascicles or decurrent down the stem, sometimes forming unclear fascicle. Leaves obliquely inserted, contiguous to subimbricate (then enclosed one to another), concave-canaliculate to canaliculate, obliquely spreading, dorsally decurrent for $2 / 3-3 / 3$ of stem width, ventrally arcuately inserted, barely or up to $1 / 2$ of stem width decurrent, larger leaves undulate at margin, rarely loosely crispate (in area adjacent to female branch), suborbicular (smaller) to obliquely ovate, 1000 $1500 \times 1100-1750 \mu \mathrm{m}$. Midleaf cells subisodiametric to oblong, 27.5-44.0 $\times 25.0-37.5 \mu \mathrm{m}$, thin-walled, trigones moderate to large, bulging; cells along leaf margin 18.5-25.0 $\mu \mathrm{m}$, thin-walled, trigones moderate to large in size, convex, rarely confluent in tangential wall, external wall thickened. Dioicous. Androecia intercalary, with 2-3 pairs of bracts, bracts smaller than leaves, strongly inflated in lower half and recurved (sometimes revolute at margin) above. Perianth conical, pluriplicate, with 5-6 main plicae, gradually narrowed to the mouth, not turbinate, ca. $1250-1400 \times 850$ $\mu \mathrm{m}$, exerted for $1 / 4-3 / 4$ of the length; perigynium well developed, ca. 1/3-1/2 of perianth length; female bracts similar to leaves, but wider, sometimes crispate, undulate at margin, sheathing the perianth in lower $1 / 3$ and concavecanaliculate ad obliquely spreading above. (Fig. 29: 9-16).

Comment. Solenostoma ovicalyx Steph. was treated as Jungermannia (Plectocolea) infusca (Mitt.) Steph. var. ovicalyx (Steph.) Amakawa. The differences suggested by Amakawa (1960: 33) are that "leaves are nearly circular and not so imbricate as in the latter [in var. infusca - VB] and the oil-bodies are fewer in number so that they do not seem to fill the cell lumen". I (as well as Amakawa) could not compare oil-body characteristics in the type material. Other differences are strongly variable, even in the type collections of the both species (holotype of Plectocolea infusca Mitt., NY00967542 was studied by me as well), thus I prefer to treat Solenostoma ovicalyx as a synonym of Plectocolea infusca.

72) Solenostoma purpurascens Steph., Sp. Hepat. 6: 82. 1917.

Holotypus: Java. Goenoeng. 1909. Miehe G537/ 00112201. 

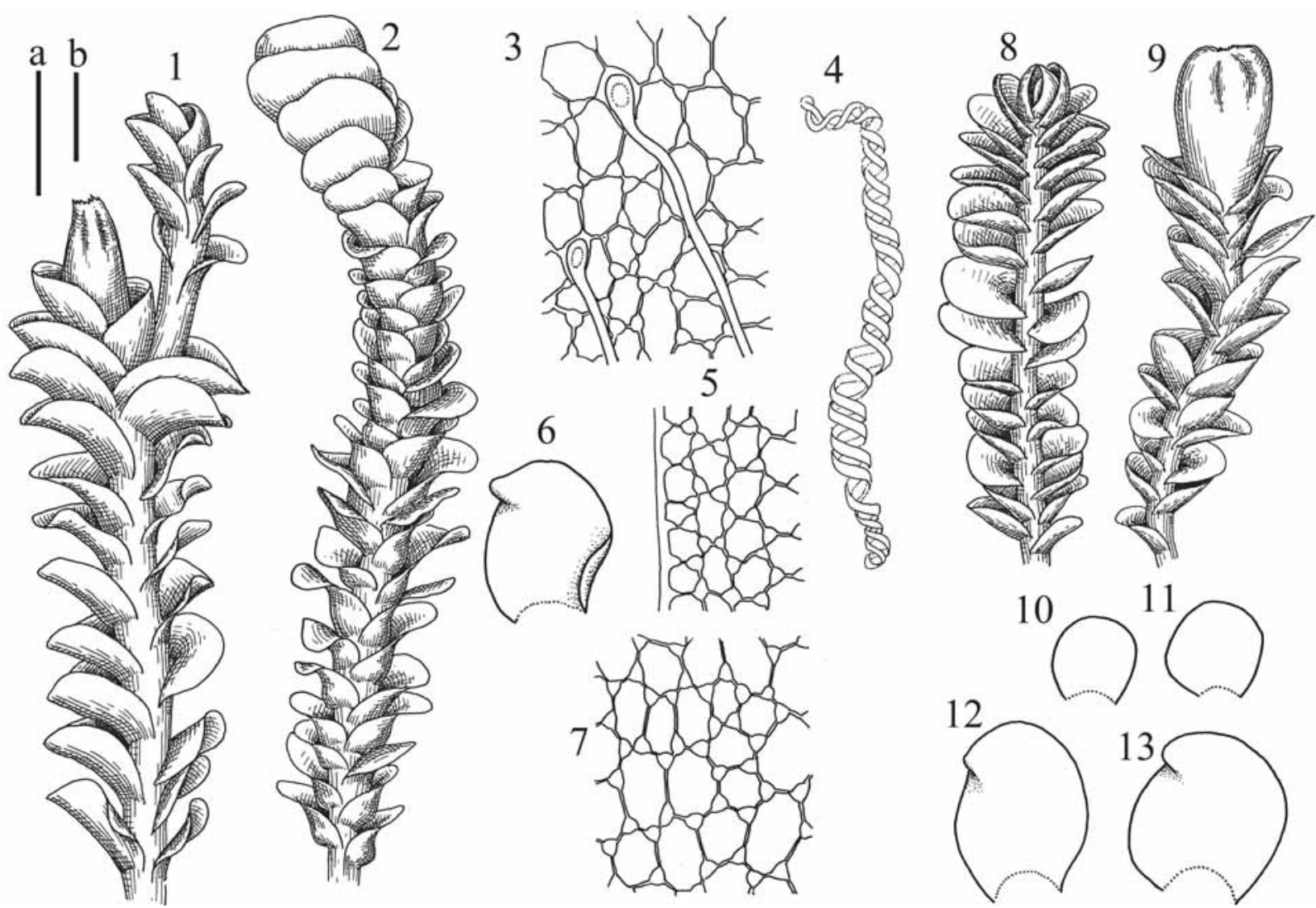

Fig. 30. Solenostoma purpurascens Steph., holotype (G537/00112201): 1 - perianthous plant; 2 - male plant; 3 - rhizogenous cells in the midleaf; 4 - elater; 5 - cells along leaf margin; 6 - leaf; 7 - midleaf cells; Solenostoma pyriflorum Steph., holotype (G668/00067160): 8 - plant habit; 9 - perianthous plant; 10-13 - leaves. Scales: a - $1.25 \mathrm{~mm}$, for 1, 2, 6; b - 100 $\mu \mathrm{m}$, for 5, 7; a $-1 \mathrm{~mm}$, for $8-13$; b $-50 \mu \mathrm{m}$, for 4 .

Accepted name: Plectocolea hasskarliana (Nees) Mitt., Flora Vitiensis, 405. 1871.

Description. Plants purplish to punk brownish, 2.02.5 (near perianth up 3.0) $\mathrm{mm}$ wide and $20-40 \mathrm{~mm}$ long. Stem $400-500 \mu \mathrm{m}$ in diameter, not branched, with the exception of lateral subfloral innovations, becoming into normal branch and easily fertilized again. Rhizoids numerous, originated from leaf lamina, decurrent down the stem in distinct fascicle, brownish to purplish. Leaves transversely to subtransversely inserted, dorsally decurrent for $1 / 2$ of stem width, ventrally decurrent for $1 / 2-2 /$ 3 of stem width, undulate, rarely loosely crispate, concave-canaliculate to canaliculate, ovate to elliptic, 1250$1400 \times 1250-1300 \mu \mathrm{m}$, contiguous to subimbricate or distant, obliquely to (rarer) erect spreading. Midleaf cells oblong, 40-75×37-50 $\mu \mathrm{m}$, thin-walled, with moderate in size, strongly convex trigones, cuticle virtually smooth; cells along leaf margin $25-32 \mu \mathrm{m}$, unequally thickened, trigones large, bulging, sometimes confluent, cuticle virtually smooth. Dioicous? Perianth conical, pluriplicate, gradually narrowed to the mouth, ca. $2500 \times 700 \mu \mathrm{m}$, exerted for $1 / 4-1 / 3$ of its length, rhizogenous in $2 / 3-3 / 4$ of its length, composed by elongated cells, cells in the perianth middle $62.5-87.5 \times 25.0-31.5 \mu \mathrm{m}$, thin-walled, with moderate in size to large, coarsely bulging trigones; peri- gynium well developed, ca. 2/3 of perianth length; female bracts similar to leaves, but wider, sheathing the perianth and loosely obliquely spreading in upper $1 / 4-1 /$ 3 of their length. (Fig. 30: 1-7).

Comment. Solenostoma purpurascens Steph. was synonymyzed by Váňa (1975a) with Jungermannia hasskarliana (Nees) Steph. (=Plectocolea hasskarliana (Nees) Mitt.), which I fully accept.

73) Solenostoma pyriflorum Steph., Sp. Hepat. 6: 83. 1917.

Holotypus: Japan. Yizogatake. 1903 U. Faurie (1293) G668/00067160.

Accepted name: Solenostoma pyriflorum Steph., Sp. Hepat. 6: 83. 1917.

Description. Plants ascending to erect, in loose patches, greenish-brownish to brownish, $1.25-1.5 \mathrm{~mm}$ wide and 5-8 $\mathrm{mm}$ long. Stem $200-275 \mu \mathrm{m}$ in diameter, loosely flexuous or straight, not branched (even as subfloral innovations). Rhizoids colorless to grayish, originated near ventral side of stem, obliquely spreading (separated or in indistinct fascicles) or decurrent down the stem, but not formed clear fascicle. Leaves subtransversely inserted, shortly, up to $1 / 4$ of stem width decurrent dorsally and transversely to loosely arcuately inserted ventrally, where not or barely decurrent, contiguous to subim- 
bricate, concave to canaliculate-concave, suborbicular to transversely elliptic, ca. $650-700 \times 850 \mu \mathrm{m}$. Midleaf cells subisodiametric to shortly oblong, $18.5-31.5 \times 15.0-22.5$ $\mu \mathrm{m}$, thin-walled, trigones moderate in size, convex, cuticle virtually smooth; cells along leaf margin 12.5-19.0 $\mu \mathrm{m}$, thin-walled, external wall thickened, trigones moderate to large, convex, rarely confluent. Dioicous. Androecia intercalary, with 2-3 pairs of bracts, male bracts similar to leaves in size, but strongly inflate in lower $2 / 3$ and obliquely spreading above. Perianth fusiform to clavate, 4-5-plicate in upper $1 / 3$, gradually narrowed to beaked mouth, bistratose in lower $2 / 3$, exerted for 3/4-4/ 5 of its length; perigynium virtually absent; female bracts similar to leaves, but wider, concave, commonly slightly recurved in upper 1/4 of the length. (Fig. 30: 8-13).

Comment. See annotation to Jungermannia pyriflora Steph.

74) Solenostoma radicellosum Mitt., J. Linn. Soc., Botany 8: 156. 1865.

Isolectotypus: Japan. Nagasaki. Oldham G531/ 265243.

Accepted name: Plectocolea radicellosa (Mitt.) Mitt., Trans. Linn. Soc. London 2, 3: 196. 1891.

Description. Plants rather erect (if possible to suggest, because only a few separated plants are in the specimen), yellowish-brownish, 2.0-2.5 mm wide and 15$25 \mathrm{~mm}$ long. Stem $375-425 \mu \mathrm{m}$ in diameter, distinctly, but not strongly flexuous, sparsely laterally branched. Rhizoids dense, originated in masses near ventral leaf bases, decurrent down the stem in distinct thick fascicle, some of rhizoids spreading upward of leaf lamina (as in P. comata), colorless to grayish. Leaves obliquely to subtransversely inserted, dorsally not or barely decurrent, ventrally subtransversely to arcuately inserted, not or barely decurrent, in general outline leaves are concave, but in dorsal part of them they are convex that gives 'plagiochiloid' appearance, leaf margin flat or narrowly incurved in dorsal side and narrowly recurved in ventral side, contiguous to subimbricate, obliquely ovate to widely obliquely ovate, rarely crispate and undulate at the margin, $1100-1300 \times 1100-1600 \mu \mathrm{m}$. Midleaf cells oblong, $37.5-50.0 \times 25.0-31.0 \mu \mathrm{m}$, thin-walled, with moderate in size to large bulging trigones, cuticle smooth; cells along leaf margin 12-22 $\mu \mathrm{m}$, obscurely thickened, trigones moderate to large, convex, rarely confluent, cuticle smooth. (Fig. 24: 10-15; 25: 1, 2).

Comment. Above placed description is well corresponding with Stephani's (1901) description as well as with plants in the lectotype in NY (NY00967552!), but disagrees with the Mitten original description (1865), especially in the rhizoid coloration and growth form. This situation (the discrepancy of type specimen features and original description) was also stressed by Amakawa, 1960).

75) Solenostoma rostratum Steph., Kungl. Svensk. Vetensk. Handl. 46(9): 16. 1911.
Holotypus: Juan Fernandez. Masafuera. 1908. Skottsberg (No. 126) G11666/00112195.

Accepted name: ?Solenostoma crassulum (Nees et Mont.) Steph., Sp. Hepat. 2: 59. 1901.

Description. Plants ascending, in dense patches, loosely attached to the substratum, $0.75-1.0 \mathrm{~mm}$ wide and 3$6 \mathrm{~mm}$ long, brownish-yellowish, with common purplish tint in the base of branches and near perianth, perianths always purplish colored, but with discolored tip, noticeable that apices of male branches brownish to brown, but not purplish. Stem 150-200 $\mu \mathrm{m}$ in diameter, brownish, sparsely laterally (sometimes it looks as terminal, but branch origin is in the leaf sinus) branched, no subfloral innovations. Rhizoids sparse to brownish, numerous, originated mostly near ventral leaf base, but not only there, obliquely to erect spreading, in unclear fascicles. Leaves concave, subtransversely inserted, not or barely decurrent dorsally, transversely to arcuately inserted ventrally, where not decurrent, contiguous to subimbricate, transversely elliptic, 375-750×575-1120 $\mu \mathrm{m}$. Midleaf cells subisodiametric to shortly oblong, 25.0-31.5×17.5$25.0 \mu \mathrm{m}$, thin-walled, cuticle smooth, trigones moderate in size, triangle to slightly convex; cells along leaf margin $17.5-27.5 \mu \mathrm{m}$, thin-walled, trigones moderate, convex, external wall thickened, cuticle virtually smooth. Dioicous. Androecia intercalary, with $2-3$ pairs of bracts; bracts strongly inflated in lower $2 / 3$, in upper $1 / 3$ recurved or sometimes even revolute. Perianth cylindrical to fusiform, 3-4-plicate in upper half, gradually narrowed to not or indistinctly beaked mouth, exerted for 3/5-3/4 of its length, composed by subisodiametric cells; female bracts similar to large leaves, concave. (Fig. 24: 16-20).

Comment. Solenostoma rostratum Steph. was synonymyzed with Jungermannia crassula Nees et Mont. (= Solenostoma crassulum (Nees et Mont.) Steph.) by Váňa (1974a).

\section{ACKNOWLEDGEMENTS}

I am deeply indebted to Mr. Matvei Bakalin for preparing figures, Dr. Michelle Price (curator of G) for constant attention and help during my sojourn in Geneva, and to Hokkaido University Museum supported the manuscript preparation as part of the "visiting professor program'. This work was also partially supported by Russian Foundation for Basic Research (grant No. 13-0400775) and grants provided by Far Eastern Branch of Russian Academy of Science.

\section{LITERATURE CITED}

AMAKAWA, T. 1960. Family Jungermanniaceae of Japan. II. - J. Hattori Bot. Lab. 22: 1-90.

AMAKAWA, T. 1966. New or little known Asiatic Species of the family Jungermanniaceae, II. - J. Hattori Bot. Lab. 29: 253-266.

AMAKAWA, T. 1967. New or little known Asiatic Species of the family Jungermanniaceae, III. - J. Hattori Bot. Lab. 30: 181-198.

AMAKAWA, T. 1968. New or little known Asiatic Species of the family Jungermanniaceae, IV. - J. Hattori Bot. Lab. 31: 101-112.

AMAKAWA, T. 1969. New or little known Asiatic Species of the family Jungermanniaceae V. - J. Hattori Bot. Lab. 32: 123-128. 
AMAKAWA, T. 1972. New or little known Asiatic species of the family Jungermanniaceae, VII. - J. Hattori Bot. Lab. 35: 382-390.

[BAKALIN, V.A.] БАКАЛИН В.А. 2009. Флора и фитогеография печеночников Камчатки и прилегающих островов. - [Flora and Phytogeography of liverworts of Kamchatka and adjacent islands]. M., Наука [Moscow, Nauka], 367 pp.

BAKALIN, V.A. 2013. New taxa of Solenostoma and Plectocolea and other taxonomic novelties based on study of collections in the New York Botanical Garden Herbarium. - Polish Bot. J. 58(1): 127-142.

ENGEL, J.J. \& D. GLENNY 2008. A Flora of the Liverworts and Hornworts of New Zealand, Vol. 1. - St.-Louis, Missouri Bot.Garden Press, $897 \mathrm{pp}$.

GRADSTEIN, S.R. 2006. Stephani's Species Hepaticarum revisited. Willdenowia 36(Special Issue): 557-563.

GOLA, G. 1914. Epatiche delle regione del Kenia. - Memorie della Reale Accademia delle Scienze di Torino, ser. 2, 65(1): 1-10.

GROLLE, R. 1965. Miscellanea hepaticologica (41-50). - J. Jap. Bot. 40: $206-219$.

INOUE, H. 1975. Illustrations of Japanese Hepaticae II. - Tsukiji Shokan Co., Tokyo, $98 \mathrm{pp}$.

KONSTANTINOVA, N.A., A.D. POTEMKIN \& R.N. SCHLJAKOV 1992. Check-list of the Hepaticae and Anthocerotae of the former USSR Arctoa 1: 87-127.

KONSTANTINOVA, N.A., BAKALIN V.A. et al. 2009. Checklist of liverworts (Marchantiophyta) of Russia. - Arctoa 18: 1-64.

MITTEN, W. 1861. Hepaticae Indiae Orientalis: an Enumeration of the Hepaticae of the East Indies. - J. Proc. Linn. Soc., Bot. 5: 89-128.

MITTEN, W. 1865. On some species of Musci and Hepaticae, additional to the floras of Japan and the coast of China. - J. Linn. Soc., London. 8 : 148-158.

SCHIFFNER, V.F. 1899. Exposition plantarum itinere suo Indico annis 1893/94 suscepto collectarum. Speciminibusque exsiccatis distributarum, adjectis descriptionibus novarum. Series prima. Hepaticarum partem continens. - Denkschriften der Kaiserlichen Akademie der Wissenschaften, Wien. Mathematisch-naturwissenschaftliche Klasse 67: 153-203

SCHUSTER, R.M. 1969. The Hepaticae and Anthocerotae of North America. Vol. 2. - New York \& London, Columbia University Press, 1062 $p p$.

STEPHANI, F. 1892a. Hepaticae Novae Caucasicae. - Botanisches Zentralblatt; referierendes Organ für das Gesamtgebiet 13(50): 70-72.

STEPHANI, F. 1892b. Hepaticae Africanae. - Hedwigia 31: 120-130.
STEPHANI, F. 1901 (1906). Species Hepaticarum. Vol. II. - Geneve et Bale, $615 \mathrm{pp}$.

STEPHANI, F. 1911. Botanische Ergebnisse der Schwedischen Expedition nach Patagonien and dem Feuerlande 1907-1909. II. Die Lebermoose. - Kungl. Svenska Vetenskapsakademiens Handlingar 46(9): $1-92$.

STEPHANI, F. 1917. Species Hepaticarum. Vol. VI. - Geneve et Bale, 1128.

VÁŇA, J. 1972a. Miscellaneous notes on the Asiatic Jungermannioideae. - J. Hattori Bot. Lab. 35: 312-318.

VÁŇA, J. 1972b. Miscellaneous notes on the Asiatic Jungermannioideae II. - J. Hattori Bot. Lab. 36: 57-74.

VÁŇA, J. 1973. Studien über die Jungermannioideae (Hepaticae) 2. Jungermannia Subg. Jungermannia. - Folia Geobot. Phytotax. 8(3): 255-309.

VÁŇA, J. 1974a. Studien über die Jungermannioideae (Hepaticae) 4. Jungermannia Subg. Plectocolea und Subg. Solenostoma: Allgemeines, süd- und mittelamericanische Arten. - Folia Geobotanica \& Phytotaxonomica. 9(2): 179-208.

VÁŇA, J. 1974b. Studien über die Jungermannioideae (Hepaticae) 5. Jungermannia Subg. Plectocolea und Subg. Solenostoma: Africanische Arten. - Folia Geobotanica \& Phytotaxonomica. 9(3): 277-312.

VÁŇA J. 1974c. Studien über die Jungermannioideae (Hepaticae) 6. Jungermannia Subg. Solenostoma: Europäische und nordamericanische Arten. - Folia Geobot. Phytotax. 9(4): 369-423.

VÁŇA, J. 1974d. Miscellaneous notes on the Asiatic Jungermannioideae. III. - J. Hattori Bot. Lab. 38: 275-282.

VÁŇA, J. 1975a. Studien über die Jungermannioideae (Hepaticae) 8. Jungermannia Subg. Plectocolea und Subg. Solenostoma in Australien, Neuseeland und Ozeanien. - Folia Geobot. Phytotax. 10(3): 277-323.

VÁŇA, J. 1975b. Studien über die Jungermannioideae (Hepaticae) 9. Jungermannia Subg. Plectocolea und Subg. Solenostoma in Hawaii; Ergänzungen und Synopsis der Gattung Jungermannia. - Folia Geobot. Phytotax. 10(4): 357-382.

VÁŇA, J. 1975c. Miscellaneous notes on the Asiatic Jungermannioideae. IV. - J. Hattori Bot. Lab. 39: 211-214.

VÁŇA, J. \& D.G. LONG 2009. Jungermanniaceae of the Sino-Himalayan region. - Nova Hedwigia 89: 485-517.

VAŇA J., L. SODERSTROM, A. HAGBORG \& M. von KONRAT 2013. Notes on Early Land Plants Today. 44. Comments on sexuality in Solenostoma (Solenostomataceae, Marchantiophyta) and on some newly described taxa. - Phytotaxa 152(1): 33-47.

\section{INDEX}

$\begin{array}{lrl}\text { Aplozia macrocarpa } & 103 & \text { J. confertissima } \\ \text { A. schauliana } & 112 & \text { J. coniflora } \\ \text { A. stephanii } & 92 & \text { J. crassula } \\ \text { A. stricta } & 93 & \text { J. danicola } \\ \text { Endogemma caespiticia } & 96 & \text { J. decolor } \\ \text { Jungermannia abyssinica } & 94 & \text { J. decurrens } \\ \text { J. amoena } & 96,109 & \text { J. dusenii } \\ \text { J. appressifolia } & 94,130 & \text { J. dussiana } \\ \text { J. atrovirens } & 109,110,127 & \text { J. duthiana } \\ \text { J. baldwinii } & 94 & \text { J. exsertifolia } \\ \text { J. bauerii } & 106 & \text { J. fauriana } \\ \text { J. borgenii } & 9,123,132 & \text { J. flavorevoluta } \\ \text { J. brasiliensis } & 95,96,109 & \text { J. fusiformis } \\ \text { J. caespiticia } & 96 & \text { J. glauca } \\ \text { J. callithrix } & 99 & \text { J. gollanii } \\ \text { J. cambewarrana } & 96,97 & \text { J. gracillima } \\ \text { J. caucasica } & 97 & \text { J. grossitexta } \\ \text { J. comata } & 116 & \text { J. hasskarliana }\end{array}$

$\begin{array}{rlr}99,121 & \text { J. herzogiana } & 129 \\ 98 & \text { J. hirticalyx } & 102,119,128 \\ 115,132,134 & \text { J. hokkaidensis } & 115 \\ 98 & \text { J. hyalina } & 103 \\ 106,107 & \text { J. infusca } & 133 \\ 99 & \text { J. inouensis } & 121 \\ 124 & \text { J. inundata } & 103,112 \\ 99 & \text { J. karsteniana } & 128 \\ 99 & \text { J. lanigera } & 121 \\ 100 & \text { J. linguifolia } & 107 \\ 99 & \text { J. macrocarpa } & 103 \\ 100 & \text { J. marcescens } & 105 \\ 131 & \text { J. mauii } & 107 \\ 102 & \text { J. micrantha } & 107,113 \\ 117 & \text { J. mieheana } & 106 \\ 103 & \text { J. mildbraedii } & 128 \\ 102 & \text { J. montana } & 106,107 \\ 133 & \text { J. mosenii } & \end{array}$


J. newellana

J. obtusiflora

J. orbiculata

J. pallida

J. papulosa

J. perloi

J. potamophila

J. prostrata

$J$. purpurata

J. pyriflora

$J$. renauldii

J. riparia

J. rufiflora

J. rupicola

J. scalariformis

J. schauliana

J. sexplicata

J. shimizuana

J. sikkimensis

J. simplicissima

J. sphaerocarpa

$J$. spongiosa

$J$. stevensiana

$J$. stricta

J. subrubra

J. subtilissima

$J$. tenerrima

$J$. thermarum

J. torticalyx

J. vaginans

$J$. virgata

J. vulcanicola

J. wattsiana

Nardia dusenii

N. fusiformis

$N$. levieri

$N$. montana

$N$. obliquifolia

$N$. prostrata

$N$. rosulans

$N$. sikkimensis

N. stolonifera

N. subrubra

$N$. verrucosa

N. vulcanicola
107 Plectocolea callithrix

107 P. comato

97 P. decolor

107, $108 \quad$ P. dusenii

95, 96, 108, $109 \quad P$. erecta

127 P. glauca

109 P. gollanii

$121 \quad P$. grossitexta

109 P. hasskarliana

109, 110, $134 \quad P$. hirticalyx

110 P. infusca

110 P. mauii

111 P. micrantha

110, $111 \quad$ P. montana

98 P. newellana

112 P. obliquifolia

113 P. obovata

102 P. prostrata

114 P. radicellosa

115 P. renauldii

99 P. rosulans

115, $116 \quad P$. rubripunctata

116 P. rupicola

129 P. sexplicata

$116 \quad$ P. sikkimensis

115 P. spongiosa

117 P. subelliptica

$108,117,118 \quad P$. torticalyx

108, 115, 116, $118 \quad$ P. truncata

119 P. virgata

122 P vulcanicola $108,117,124,125,126$

$P$. yunnanensis

103, 119, 128 Solenostoma abyssinicum

120, 124 S. amoenum

100 S. aomorense

120, 121 S. appalachianum

102, 128, 129 S. appressifolium

121 S. atrovirens

121 S. australe

122 S. bauerii

114 S. borgenii

122, 123 S. caucasicum

116 S. cinereum

124 S. clavellatum
114

S. coniflorum

106 S. crassulum

120,124

122

102

101,117

$102,107,108,116$

133,134

119

$119,132,133$

107,113

$94,107,113$

$102,119,128$

107

121

115

121

134

110

122

113

111

113

114

115,116

115

$102,108,115,118$

113

122

S. decolor

S. duthianum

S. faurianum

S. flavorevolutum

S. fusiforme $100,124,127,130,131$

S. gollanii

S. gracillimum

S. inundatum

S. koreanum

S. lacouturei

S. lanigerum

S. levieri

S. linguifolium

S. macrocarpum

S. marcescens

S. mildbraedii

S. obscurum

S. obtusiflorum

S. obtusiflos

S. orbiculatum

S. ovalifolium

S. ovicalyx

S. papulosum

S. perloi

S. purpurascens

S. purpuratum

S. pyriflorum

S. radicellosum

S. rostratum

94 S. rosulans

96, 99

127

127

94, 130

127,128

$103,119,128$

105, 106

S. rupicolum

S. rufiflorum

S. sanguinolenthum

S. schaulianum

S. shimizuanum

S. sikkimense

123

S. sphaerocarpum

S. stephanii

97 S. stoloniferum

129 S. strictum

100 S. subrubrum
99, 121

98

$115,132,134$

107

100

99

100

130

104

103

$127,130,131$

131

121

120, 121

107

104

105

106

115

132

132

96, 97

115

132, 133

$65,96,108,109$

127,128

133

109, 130

109, 110, 127, 134

134

132, 134

111

111

111

105

112

102

114

98

92

123,132

93, 129

116

117, 124, 125, 126 